RENATO MORETTINI

TECNOLOGIAS CONSTRUTIVAS PARA A REABILITAÇÃO DE EDIFÍCIOS: TOMADA DE DECISÃO PARA UMA REABILITAÇÃO SUSTENTÁVEL 
RENATO MORETTINI

\section{TECNOLOGIAS CONSTRUTIVAS PARA A REABILITAÇÃO DE EDIFÍCIOS: TOMADA DE DECISÃO PARA UMA REABILITAÇÃO SUSTENTÁVEL}

Dissertação apresentada à Escola Politécnica da Universidade de São Paulo para obtenção do título de Mestre em Engenharia

Área de concentração: Engenharia Civil.

Orientador: Prof $\stackrel{\text { a }}{\text { Dra }}$. Mercia Maria S. Bottura de Barros

São Paulo 
Este exemplar foi revisado e alterado em relação à versão original, sob responsabilidade única do autor e com a anuência de seu orientador.

São Paulo, de de 20

Assinatura do autor

Assinatura do orientador

FICHA CATALOGRÁFICA

Morettini, Renato

Tecnologias construtivas para a reabilitação de edifícios: tomada de decisão para uma reabilitação sustentável / $\mathbf{R}$. Morettini. -- ed. rev. -- São Paulo, 2012. $130 \mathrm{p}$.

Dissertação (Mestrado) - Escola Politécnica da Universidade de São Paulo. Departamento de Engenharia de Construção Civil.

1. Edifícios (Reabilitação) 2. Sustentabilidade 3. Tomada de decisão I. Universidade de São Paulo. Escola Politécnica. Departamento de Engenharia de Construção Civil II. t. 


\section{AGRADECIMENTOS}

Agradeço a todos que colaboraram com este trabalho. Aos meus pais, dedico os mais importantes votos de agradecimento. Pelo apoio nas decisões e pelo constante suporte durante todo o processo. Ao meu irmão Mauricio Morettini pelo suporte sempre quando necessário. E à Fernanda Santucci, que aguentou firmemente os momentos de sofrimento e as ausências, estando sempre presente, com alegria e motivação.

À prof. Mercia Maria Semensato Bottura de Barros, expresso profunda gratidão pela orientação e direcionamento a todo tempo, a qual considero a grande responsável pela qualidade do trabalho realizado. Pela indiscutível competência em orientar da melhor forma não só o trabalho de Mestrado, mas também o crescimento pessoa e pesquisador.

Aos professores do grupo de pesquisa de Tecnologia e Gestão da Produção de Edifícios, prof. Fernando Henrique Sabbatini, prof. Francisco Ferreira Cardoso, Prof. Ubiraci Espinelli Lemes de Souza e prof. Silvio Burattino Melhado, pela contribuição, principalmente durante as disciplinas.

Aos colegas que participaram e colaboraram na minha formação como engenheiro, minha família durante os anos na Universidade Estadual de Campinas, principalmente os que dividiram o lar durante esse período: André Jenkino, Andrez Marufuji, Daniel Silvério, Eduardo Toshio, Elcio Netto, Guilherme Meira, Hélio Higashi, Joka Chiaradia, Roberto Moura, Rodrigo Salustiano, Victor Macedo.

Não posso deixar de agradecer aos colegas da Poli, que participaram diretamente do trabalho, compartilhando os momentos de tensão e desempenhando um exímio trabalho de equipe nas lutas do dia a dia. Agradecimento especial aos grandes amigos da Sala Buraco Negro: Jamil José Salim Neto, Flávia Rodrigues de Souza, Camila Kato, Felipe Morasco, Adriana Gouveia Rodrigo, Claudio Ferreira Jr. e Ricardo Oviedo Haito. E aos demais amigos que colaboraram: Fernanda Belizário Silva, Daniel Godoy, Cintia Aparecida, Cilene Marques e todos os demais colegas de Mestrado. 


\section{RESUMO}

À medida que os edifícios se tornam obsoletos, seja pelo não atendimento às condições normais de uso, seja pela necessidade de incorporar elementos que melhorem o desempenho e a eficiência deste edifício, a sua reabilitação se mostra não somente viável como necessária. Grande parte dos impactos gerados pelo setor da construção civil provém dos edifícios existentes, que não foram concebidos segundo os conceitos de sustentabilidade atualmente aplicados. Por isto, reabilitar um edifício para torná-lo mais sustentável contribui para a redução dos impactos gerados no meio ambiente.

Realizar uma reabilitação para tornar um edifício mais sustentável é possível através da introdução de novas tecnologias aos sistemas deste edifício que se mostram obsoletos. A tomada de decisão sobre o conjunto de tecnologias construtivas a serem utilizadas na reabilitação de um edifício deve ser realizada de acordo com as potencialidades de intervenção e limitações do próprio edifício, sendo que a escolha da melhor alternativa depende de diversas variáveis, específicas para cada empreendimento.

Desta forma, o objetivo deste trabalho é propor um processo para auxiliar a decisão dentre diferentes tecnologias de forma a tornar a reabilitação mais sustentável, sobretudo do ponto de vista ambiental. Para tanto, a metodologia foi baseada em estudos bibliográficos que, a partir da proposição de um processo de decisão, possibilitaram a definição de requisitos de sustentabilidade a serem considerados, além de tecnologias construtivas que atendem a estes requisitos.

Espera-se, assim, que o presente trabalho possa contribuir para o processo de reabilitação de edifícios, estimulando o desenvolvimento sustentável desta atividade, contribuindo também para a redução de danos ao meio ambiente.

Palavras-chave: edifícios (reabilitação); sustentabilidade; tomada de decisão. 


\begin{abstract}
As buildings become obsolete, by not achieving the normal conditions of use, or by the need for incorporating elements to improve performance and efficiency of the building, rehabilitation shows to be not only feasible but necessary. Most impacts generated by the construction industry come from existing buildings, which were not designed according to sustainability concepts. Therefore, building rehabilitation can contribute to the reduction of environmental impacts.
\end{abstract}

Rehabilitation to make buildings more sustainable is possible through the introduction of new construction technology improving systems of nonsustainable buildings. Decision making on a set of building technologies to be used in the rehabilitation of a building should be carried out according to the limitations of the building itself, and choosing the best alternative depends on several variables, specific to each project.

Thus, the objective of this work is to propose a process to assist the decision among different technologies to make a sustainable rehabilitation by environment point of view. For this purpose, the methodology was based on a revision of the literature, first by the proposition of a decision making process that could support the definition of sustainability requirements to be considered in addition to building technologies that meet these requirements.

Therefore, this work can be a contribution to the building rehabilitation process , encouraging sustainable development and contributing to the reduction of environmental damage in this activity.

Keywords: building (rehabilitation); sustainability; decision making. 


\section{LISTA DE ILUSTRAÇÕES}

Figura 2.1 - Atividades compreendidas pelo processo de reabilitação de edifícios inseridas na atividade de construção civil. Fonte: MARQUES DE JESUS (2008).

Figura 2. 2 - Fluxograma com as fases da reabilitação. REABILITA (2007) .... 16

Figura 2.3 - Modelo de processo de projeto para a reabilitação de edifícios (Roders, 2006. Tradução de Croitor, 2008)................................................... 22

Figura 3.1 - O processo de decisão segundo Clemen (1991)....................... 45

Figura 3. 2 - Fluxograma do processo de tomada de decisão......................... 49

Figura 3.3 - Estrutura hierárquica básica (SCHIMIDT, 1995)........................ 53

Figura 3. 4 - Níveis de hierarquia (SAATY, 1991)....................................... 54

Figura 3.5 - Obtenção da classificação final das alternativas (SOUZA, 2003). 57

Figura 3.6 - Os três planos do escopo para a avaliação de sustentabilidade em edifícios. Fonte: Larsson (2010). (Tradução do autor) 61

Figura 3.7 - Aspectos relevantes para a avaliação de sustentabilidade de edifícios. Fonte: Larsson (2010). (Tradução do autor) 62

Figura 3.8 - Requisitos da metodologia PH\&E (Tradução do autor). 70 


\section{LISTA DE QUADROS}

Quadro 3.1 - Etapas do processo de decisão. 48

Quadro 3.2 - Modelo de matriz de decisão (SALOMON e MONTEVECHI, 1999).

Quadro 3.3 - MCP para os critérios do nível 1 54

Quadro 3.4 - MCP para os critérios do nível 2, relacionados ao critério 1....... 55

Quadro 3.5 - MCP para os critérios do nível 2, relacionados ao critério 4....... 55

Quadro 3.6 - Preenchimento da MCP (adaptado de ASTM E 1765, 1998) ..... 56

Quadro 3.7 - Esquema para determinação das MCP para os critérios (adaptado de Souza, 2003).

Quadro 3.8 - Resumo dos requisitos relacionados às metodologias de avaliação de edifícios.

Quadro 3.9 - Comparativo entre requisitos propostos pelas metodologias de avaliação de sustentabilidade.

Quadro 4.1 - Revestimentos não aderidos (vedação externa). $\quad 90$

Quadro 4.2 - Fachada cortina de vidro (vedação externa). 91

Quadro 4.3 - Parede em gesso acartonado (vedação interna)......................... 92

Quadro 4.4 - Bloco de concreto celular autoclavado (vedação interna). ......... 93

Quadro 4.5 - Forro suspenso (vedação interna)........................................... 94

Quadro 4.6 - Piso elevado (vedação interna) ……….................................... 95

Quadro 4.7 - Instalações integradas pré montadas (instalações hidráulicas). . 96

Quadro 4.8 - Tubulação de polietileno reticulado flexível (instalações hidráulicas)

Quadro 4.9 - Esgoto a vácuo (instalações hidráulicas). .................................... 98

Quadro 4.10 - Ar condicionado VRV (instalações de ar condicionado)............ 99

Quadro 4.11 - Lâmpadas LED (instalações elétricas)................................... 100

Quadro 4.12 - Painéis fotovoltaicos (sistemas de geração de energia). ........ 101

Quadro 5.1 - Matriz de comparação paritária (MCP). 109 
Quadro 5.2 - Ponderação dos critérios de decisão. ..................................... 110

Quadro 5.3 - Índice de redução sonora ponderado da fachada, $R_{\mathrm{w} . \ldots \ldots \ldots . . . . .113}$

Quadro 5.4 - Obtenção da classificação final das alternativas....................... 115 


\section{LISTA DE ABREVIATURAS E SIGLAS}

\begin{tabular}{|c|c|}
\hline ABNT & Associação Brasileira De Normas Técnicas \\
\hline ACV & Avaliação do Ciclo de Vida \\
\hline AHP & Analytic Hierarchy Process \\
\hline AQUA & Alta Qualidade Ambiental \\
\hline ASTM & American Society for Testing and Materials \\
\hline BCSD & Business Council for Sustainable Development \\
\hline BEE & Building Environmental Efficiency \\
\hline BIM & Building Information Modeling \\
\hline BRE & Building Research Establishment \\
\hline BREEAM & $\begin{array}{l}\text { Building Research Establishment Environmental Assessment } \\
\text { Method }\end{array}$ \\
\hline CASBEE & $\begin{array}{l}\text { Comprehensive Assessment System for Building Environmental } \\
\text { Efficiency }\end{array}$ \\
\hline CIB & $\begin{array}{l}\text { International Council for Research and Innovation in Building and } \\
\text { Construction }\end{array}$ \\
\hline CIOB & The Chartered Institute Of Building \\
\hline $\mathrm{CO}_{2}$ & Dióxido de Carbono \\
\hline CONAMA & Conselho Nacional do Meio Ambiente \\
\hline CRISP & Construction Related Sustainability Indicators \\
\hline DTI & Department of Trade and Industrie \\
\hline EPI & Environmental Performance Index \\
\hline FCAV & Fundação Carlos Alberto Vanzolini \\
\hline FA & Fator Altura \\
\hline FF & Fator Forma \\
\hline FV & Fotovoltaico \\
\hline GBC & Green Building Council \\
\hline GBTool & Green Building Tool \\
\hline HQE & é Environnementale du Bâtiment \\
\hline
\end{tabular}




$\begin{array}{ll}\text { HUD } & \text { U.S. Department of Housing and Urban Development } \\ \text { IBEC } & \text { Institute for Building Environment and Energy Conservation } \\ \text { IBGE } & \text { Instituto Brasileiro de Geografia e Estatística } \\ \text { IC }{ }_{\text {env }} & \text { Indicador de Consumo da Envoltória } \\ \text { INMETRO } & \text { Instituto Nacional de Metrologia, Normalização e Qualidade } \\ & \text { Industrial } \\ \text { iiSBE } & \text { International Initiative for a Sustainable Built Environment } \\ \text { IPCC } & \text { Intergovernmental Panel on Climate Change } \\ \text { LED } & \text { Light Emitting Diode } \\ \text { LEED } & \text { Leadership in Energy and Environmental Design } \\ \text { MACBETH } & \text { Measuring Attractiveness by a Categorical Based Evaluation } \\ \text { MAUT } & \text { Technique } \\ \text { MCDA } & \text { Multi-attribute Utility Theory } \\ \text { MCP } & \text { Multi Criteria Decision Aid } \\ \text { NARRP } & \text { Matriz de Comparação Paritária } \\ \text { OEE } & \text { Nationally Applicable Recommended Rehabilitation Provisions } \\ \text { ONU } & \text { Office Of Energy Efficiency } \\ \text { PBE } & \text { Organização das Nações Unidas } \\ \text { PEX } & \text { Programa Brasileiro de Etiquetagem } \\ \text { PH\&E } & \text { Crosslinked Polyethilene } \\ \text { PROCEL } & \text { Patrimoine Habitat \& Environment } \\ \text { PVC } & \text { Programa Nacional de Conservação de Energia Elétrica } \\ \text { QAE } & \text { Qualinyl chloride } \\ \text { Rw } & \text { Índice De Redução Sonora Ponderado } \\ \text { SBTool } & \text { Sustainable Building Tool } \\ \text { SDC } & \text { Sustainable Development Commission } \\ \text { SGE } & \text { Sistema de Gestão do Empreendimento } \\ \text { USGBC } & \text { United States Green Building Council } \\ \text { VRV } & \text { Volume de Refrigerante Variável } \\ & \end{array}$




\section{SUMÁRIO}

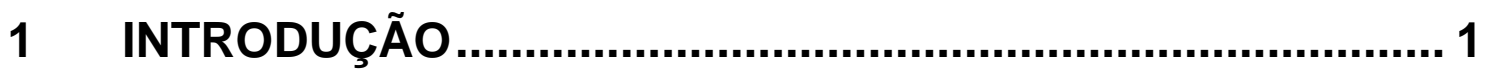

1.1 Contextualização .......................................................................... 1

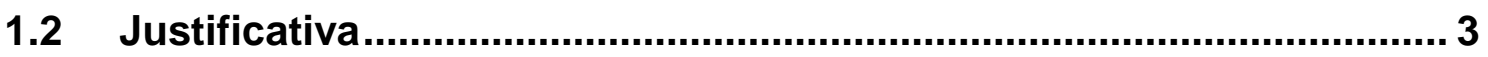

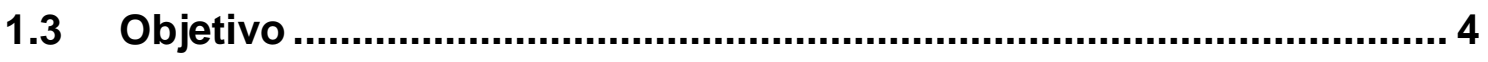

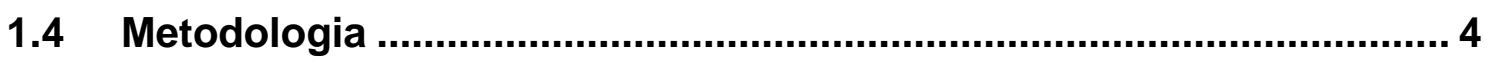

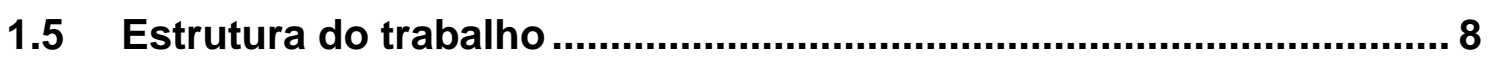

2 REABILITAÇÃO E SUSTENTABILIDADE DE EDIFÍCIOS .. 10

2.1 contexto da reabilitação de edifícios ............................................. 10

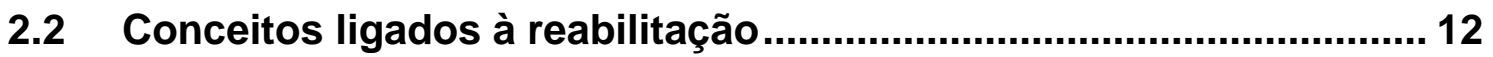

2.3 Características e particularidades do processo de produção da

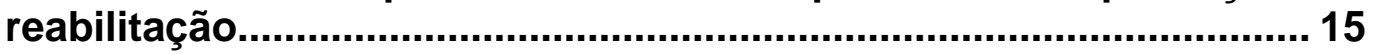

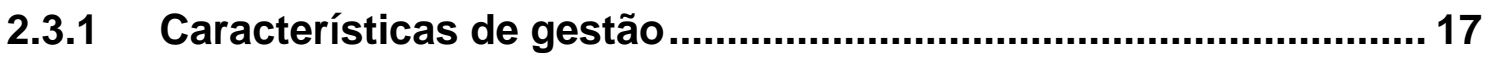

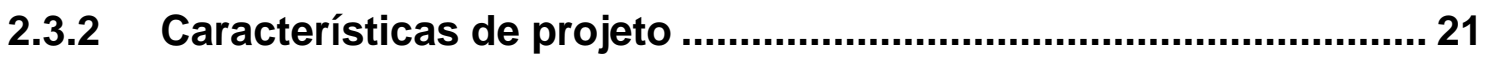

2.3.3 Características da execução e dos métodos construtivos ............ 23

2.4 Sustentabilidade na construção ...................................................... 27

2.5 A reabilitação de edifícios com base nos conceitos de sustentabilidade ............................................................................... 32

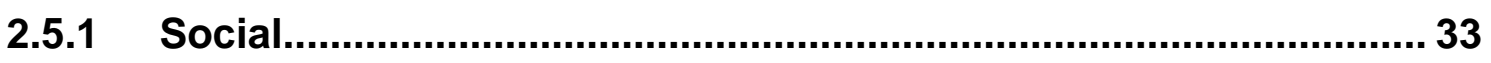

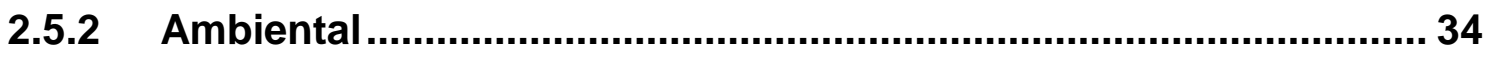

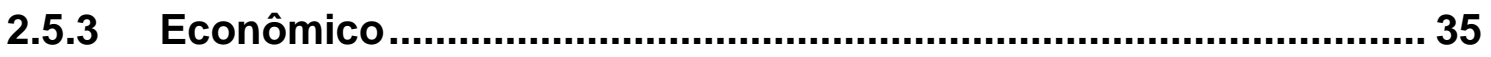

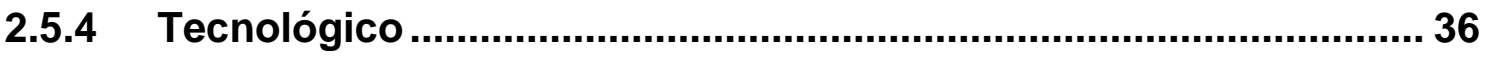

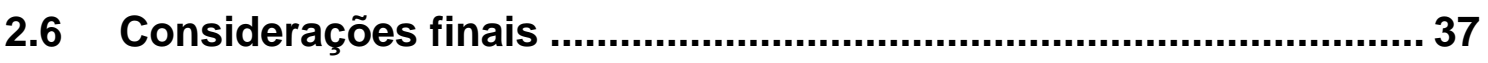




\section{A SUSTENTABILIDADE COMO BASE PARA A TOMADA DE DECISÃO............................................................................. 40}

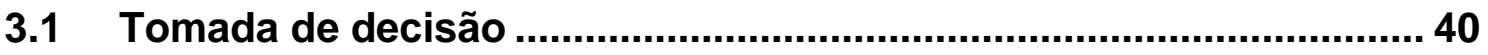

3.1.1 Dificuldades e limitações na tomada de decisão ............................. 41

3.1.2 O processo de tomada de decisão .................................................. 44

3.1.3 Modelos como ferramenta de apoio à decisão............................... 49

3.1.4 O método AHP (Analytic hierarchy process) ….............................. 52

3.1.5 O processo de tomada de decisão no contexto de reabilitação de edifícios sustentáveis ................................................................. 57

3.2 Avaliação do grau de sustentabilidade de um edifício ..................... 58

3.3 Metodologias de avaliação de sustentabilidade de edifícios ............60

3.4 Identificação dos requisitos de sustentabilidade relevantes na .........

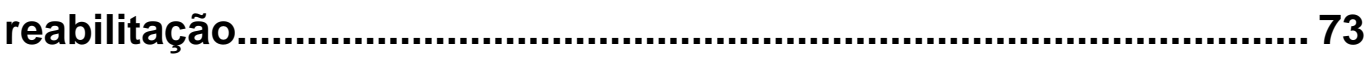

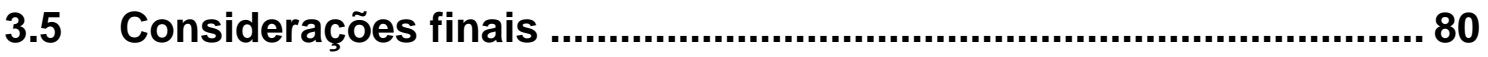

4 TECNOLOGIAS CONSTRUTIVAS PARA A REABILITAÇÃO DE EDIFÍCIOS ................................................................... 82

4.1 Levantamento de alternativas Tecnológicas sustentáveis para reabilitação

4.2 Tecnologias sustentáveis: características e aplicação na reabilitação de edifícios .................................................................... 87

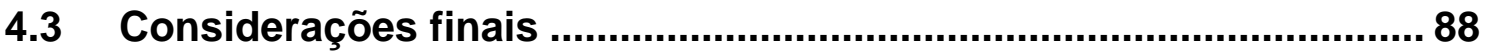




\section{PROCESSO DE TOMADA DE DECISÃO APLICADO À ESCOLHA DE TECNOLOGIAS CONSTRUTIVAS ...................... 102}

5.1 Definição da diretriz balizadora do processo ................................. 102

5.2 Caracterização do problema........................................................ 103

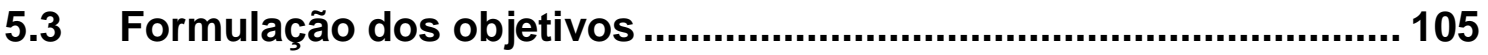

5.4 Definição dos critérios de decisão ................................................. 106

5.5 Ponderação dos critérios de decisão .......................................... 107

5.6 Identificação das alternativas..................................................... 110

5.7 Levantamento das informações de cada alternativa....................... 111

5.8 Avaliação e seleção das alternativas............................................... 114

6 CONSIDERAÇÕES FINAIS ............................................. 116

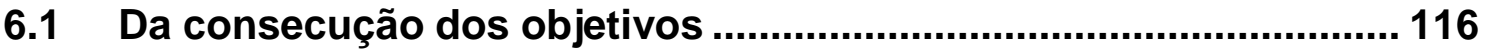

6.2 Sugestões para trabalhos futuros ................................................ 117 


\section{INTRODUÇÃO}

\subsection{Contextualização}

Com o aumento da população mundial e o desenvolvimento da economia, os recursos naturais passam a ser motivo de preocupação para a sociedade. De acordo com o CIB (2002), nos países em desenvolvimento, a rápida urbanização e as pressões mundiais relacionadas à redução do consumo de recursos naturais têm gerado grande demanda por intervenções sustentáveis no ambiente construído.

Nesse contexto o setor da construção tem sido alvo das atenções, uma vez que é conhecido como o setor dos $40 \%$, ou seja, considerando-se toda a cadeia produtiva da construção, desde a manufatura de componentes até as atividades operacionais é responsável por $40 \%$ do total de recursos consumidos e por $40 \%$ de toda a produção de resíduos (CIB, 1999).

Dessa forma, o desenvolvimento sustentável da construção é de responsabilidade de todos os agentes da cadeia produtiva. Clientes devem exigir um ambiente construído sustentável, profissionais do setor devem adotar práticas construtivas sustentáveis, a indústria da construção deve se comprometer a desenvolver produtos e processos sustentáveis e o governo deve promover, possibilitar e reforçar a necessidade de se construir de forma sustentável (CIB, 2002).

A preocupação com o consumo indiscriminado de recursos naturais e com a redução da emissão de gases do efeito estufa tem resultado em diversas ações que visam minimizar o impacto causado pela atividade humana (IPCC, 2007). Além de ações globais, como o Protocolo de Kyoto (ONU, 1998), diversos países, entre eles os do Reino Unido (SDC, 2007), o Canadá (OEE, 2009), os Estados Unidos (HOLNESS, 2009) e o Brasil (BRASIL, 2009) definiram metas próprias de redução de emissão de gases que abrangem os diferentes setores da economia. 
O estabelecimento de tais metas tem levado a iniciativas de incentivo à construção sustentável, seja por parte de instituições governamentais ou do setor privado que, ao reforçarem o comprometimento com a sustentabilidade ambiental, demandam, cada vez mais, edifícios que reflitam seus valores. Essa tendência é suportada pela consciência de que um edifício bem projetado e operando corretamente aumenta o conforto, a saúde e a produtividade dos seus usuários, além de minimizar o consumo de recursos (ARUP, 2009).

Contudo, apesar da nova demanda pela construção de edifícios sustentáveis, a maioria dos edifícios existentes não foi concebida com base nesses conceitos e, de acordo com Holness (2009), a maior parte dos edifícios que existirão em áreas urbanas em 2030 já existem hoje.

Segundo o mesmo autor, a maior parcela do consumo energético nos Estados Unidos ocorre nos edifícios, sendo esses responsáveis por $72 \%$ do consumo total de energia elétrica naquele país. Por isso, Holness (2009) afirma que a oportunidade para garantir a redução global do uso de energia primária deve ter como principal foco os edifícios existentes.

No Brasil, dados do município de São Paulo revelam que o parque imobiliário da área central apresenta-se obsoleto, com grande parte dos imóveis vagos. Segundo Bomfim (2004), isto está relacionado com aspectos como o deslocamento populacional para outras regiões, a deterioração dos imóveis e da região central e o direcionamento da produção imobiliária.

A degradação de áreas centrais das cidades tem sido um processo inerente à dinâmica urbana. $\mathrm{O}$ esvaziamento de regiões mais antigas acontece ao mesmo tempo em que novas regiões são ocupadas, ocorrendo grande produção imobiliária. A busca por edifícios mais modernos e que atendam às novas exigências do mercado tem provocado o deslocamento das empresas para fora dos centros urbanos (YOLLE NETO, 2006). 
Toma-se como exemplo o município de São Paulo que, atualmente, possui cerca de 450 mil $^{1}$ imóveis ociosos entre casas e edifícios, principalmente nas regiões mais centrais. Nos distritos Sé e República, por exemplo, edifícios antigos, construídos até o final da década de 1950, necessitam de reforma das instalações elétricas e hidráulicas, dos sistemas de segurança, das esquadrias, além de outros componentes (REABILITA, 2007).

Em contrapartida, a área central da cidade de São Paulo possui infraestrutura bem desenvolvida (REABILITA, 2007). Assim, a reabilitação urbana e dos edifícios dessas áreas pode contribuir para o seu desenvolvimento sustentável.

Nesse cenário, a readequação dos edifícios antigos, visando à sua reintrodução na dinâmica da cidade mostra-se não somente viável como completamente necessária.

\subsection{Justificativa}

Segundo Bullen (2007), qualquer edifício construído necessita de intervenções ao longo do seu ciclo de vida. Às vezes, o espaço físico de um edifício está em condições adequadas de uso, mas seus sistemas prediais estão ultrapassados.

Os avanços tecnológicos, relacionados principalmente à comunicação e automação dos edifícios, e à demanda dos usuários por maior conforto dos ambientes contribuem para a rápida obsolescência das edificações e exigem seu processo de reabilitação (LANGSTON et al., 2008), visando à sua readequação ao uso.

Por meio de intervenções em diferentes níveis, a reabilitação proporciona inúmeros benefícios e vantagens quando comparada a uma construção nova, entre eles, menor consumo de recursos naturais, humanos e energéticos (BULLEN, 2007).

Não obstante à forte necessidade de atividades de reabilitação, este é um mercado que, pela sua complexidade, não tem atraído muitas empresas. Trata-

\footnotetext{
${ }^{1}$ Dados do Censo 2010 (IBGE, 2011), que consideram domicílios particulares não-ocupados vagos, fechados ou de uso ocasional.
} 
se de um novo nicho que ainda precisa ser devidamente conhecido e explorado.

As características das obras de reabilitação são, em grande parte, distintas daquelas encontradas em construções novas, pois envolvem a recuperação de elementos e subsistemas dos edifícios, além de se ter alto grau de complexidade na logística e administração do canteiro de obras (MARQUES DE JESUS et al., 2007).

Yolle Neto (2006), analisando diversos empreendimentos de reabilitação, verificou que não houve uma metodologia específica para intervenção, pois não havia, até então, experiências sistematizadas nesse segmento da construção civil. Os conceitos adotados e as técnicas de intervenção foram adaptados daqueles utilizados em obras novas, os quais nem sempre são adequados à situação de intervenção em um edifício existente. Não obstante os avanços ocorridos desde então, sobretudo com a proposta metodológica apresentada pelo projeto REABILITA (2007), muitas dúvidas ainda permanecem em relação ao processo de reabilitação. Dentre elas, a necessidade de parâmetros que permitam a escolha de tecnologias mais adequadas à sua realização, sobretudo visando à sustentabilidade ambiental do edifício, sendo este, pois, o tema do presente trabalho, cujo objetivo é apresentado na sequência.

\subsection{Objetivo}

O objetivo do presente trabalho é propor um processo para a tomada de decisão quanto às possíveis soluções tecnológicas, dentre um conjunto de tecnologias construtivas, para serem aplicadas à reabilitação sustentável de edifícios.

\subsection{Metodologia}

A base metodológica da pesquisa foi a análise documental, pela qual se buscou o entendimento de documentos relacionados aos temas abordados, tais como: livros, artigos de jornais, artigos técnicos de eventos consagrados, além de pesquisas acadêmicas, periódicos e revistas técnicas reconhecidas pelos institutos de apoio à pesquisa e normas técnicas. 
Para contextualizar a reabilitação de edifícios, foi realizada uma pesquisa documental sobre a definição do conceito. Assim, a partir da análise de diferentes termos utilizados em diversos trabalhos científicos, justificou-se a utilização do termo reabilitação de edifícios. As principais palavras chave utilizadas para a pesquisa estão apresentadas no Quadro 1.1.

\begin{tabular}{|c|c|c|c|}
\hline Português & Inglês & Francês & Espanhol \\
\hline $\begin{array}{l}\text { Reabilitação de } \\
\text { Edifícios } \\
\text { Reforma de Edifícios } \\
\text { Recuperação de } \\
\text { Edifícios } \\
\text { Requalificação de } \\
\text { Edifícios } \\
\text { Renovação de } \\
\text { Edifícios } \\
\text { Reparo de edifícios }\end{array}$ & $\begin{array}{l}\text { Building } \\
\text { Rehabilitation } \\
\text { Retrofit } \\
\text { Refurbishment } \\
\text { Home improvement } \\
\text { Renovation } \\
\text { Renewal } \\
\text { Repair } \\
\text { Adaptive reuse }\end{array}$ & $\begin{array}{l}\text { Réhabilitation } \\
\text { Récupération } \\
\text { Réforme }\end{array}$ & $\begin{array}{l}\text { Rehabilitación } \\
\text { Recuperación } \\
\text { Reforma } \\
\text { Remodelación }\end{array}$ \\
\hline
\end{tabular}

Quadro 1.1 - Palavras chave relacionadas à reabilitação de edifícios utilizadas na pesquisa bibliográfica.

Outro objetivo da contextualização da reabilitação de edifícios foi a identificação das suas características e particularidades, para se entender as diferenças entre um empreendimento de reabilitação e a construção de um edifício novo.

Para isso, além da pesquisa bibliográfica, foram realizadas entrevistas não estruturadas com diferentes agentes do setor, nas quais os principais questionamentos eram relacionados às diferenças entre a reabilitação e a construção de um edifício novo, além dos principais problemas identificados na execução de um empreendimento de reabilitação. Entre os entrevistados, incluem-se um projetista, um engenheiro e um arquiteto coordenador de projetos de uma grande construtora de São Paulo, além de empreiteiros do 
setor da construção civil que participaram de empreendimentos de reabilitação de edifícios.

As principais características da reabilitação, identificadas a partir da realização das entrevistas, estão relacionadas às incertezas deste tipo de empreendimento, registradas no capítulo 2. Essas entrevistas não foram incluídas de forma explícita no trabalho, contudo, foram fundamentais para o entendimento do autor acerca do contexto da reabilitação de edifícios no Brasil e dos desafios e oportunidades referentes a esta atividade no país.

Com relação aos conceitos de sustentabilidade, foi realizada uma análise documental de trabalhos acadêmicos, relatórios técnicos e propostas visando à certificação ambiental de edifícios, buscando-se compreender como os conceitos de sustentabilidade e, em particular os que afetam o meio ambiente, podem ser aplicados às atividades de reabilitação. Partiu-se da busca de conceitos associando-se as palavras chave "sustentabilidade" e "desenvolvimento sustentável" à palavra "construção" e também às citadas no Quadro 1.1.

Em seguida, também a partir de pesquisa documental, foram identificadas e estudadas metodologias de auxílio à decisão, com vistas a se propor um processo que possa auxiliar projetistas de empreendimentos de reabilitação quanto à escolha de tecnologias construtivas passíveis de tornarem 0 empreendimento ambientalmente mais sustentável.

Considerando-se o processo de decisão proposto e as metodologias de auxílio à decisão identificou-se a necessidade de se definir critérios para escolha de tecnologias.

Uma vez que o trabalho considera a possibilidade de reabilitação de qualquer tipo de edifício sem valor histórico (ou seja, não inclui a restauração), a definição de critérios quantitativos depende de cada tipo específico de reabilitação - a reabilitação de um edifício comercial pode ter critérios de escolha muito distintos da reabilitação de um edifício para habitação de interesse social, por exemplo. Por esse motivo, não foram definidos critérios, 
mas sim requisitos qualitativos, de forma a auxiliar a definição dos critérios específicos para cada caso, na aplicação do processo de tomada de decisão.

A definição dos requisitos para a tomada de decisão foi feita com base nos conceitos de sustentabilidade, considerando-se, majoritariamente os requisitos ambientais, sem deixar de lado os sociais e econômicos que, muitas vezes, decorrem daqueles. Requisitos importantes para a decisão, como custo e riscos mercadológicos associados às alternativas não foram considerados, uma vez que se desejava não limitar as possibilidades tecnológicas a serem estudadas, até porque essas duas variáveis dependem muito do tipo de empreendimento. Contudo, na prática, esses requisitos deverão estar incluídos no processo de tomada de decisão, sendo fundamental a sua consideração na escolha de tecnologias para a reabilitação.

Os requisitos de sustentabilidade foram definidos com base nos propostos por metodologias de certificação de sustentabilidade. Para isso, foi feito um levantamento das principais metodologias consolidadas mundialmente (SBTool, BREEAM, LEED, CASBEE, HQE, e PH\&E) e das desenvolvidas para a realidade da construção de edifícios no Brasil (AQUA, PROCEL EDIFICA, CASA AZUL).

Os requisitos propostos por essas metodologias foram analisados $\mathrm{e}$ comparados entre si. Essa comparação somada às características da reabilitação de edifícios, descritas no capítulo 2, possibilitaram propor requisitos para a escolha de tecnologias construtivas a serem utilizadas em uma reabilitação.

Com base nos requisitos definidos, foram identificadas tecnologias passíveis de serem utilizadas na reabilitação. Para isso, foi realizada uma busca de artigos técnicos, livros, catálogos de fabricantes e outros documentos sobre tecnologias para a reabilitação, além do levantamento das tecnologias construtivas utilizadas em novas construções, analisando-se a possibilidade de utilização destas na reabilitação de edifícios.

O levantamento de tecnologias realizado foi direcionado aos subsistemas vedação interna e externa, instalações elétricas, hidráulicas e de climatização, 
além de sistemas de geração de energia. A definição destes subsistemas como objeto de estudo decorre de serem esses os subsistemas que apresentam a maior necessidade de intervenção em obras de reabilitação, como descrito no capítulo 5.

Assim, com as ferramentas de apoio à tomada de decisão, os critérios de decisão identificados e o levantamento de tecnologias passíveis de serem utilizadas na reabilitação, foram discutidas as possibilidades de aplicação do processo de decisão na reabilitação de edifícios utilizando as informações apresentadas.

\subsection{Estrutura do trabalho}

O trabalho está desenvolvido ao longo de seis capítulos. No capítulo 1 o tema do trabalho é descrito, apresentando-se o contexto e as justificativas de forma a se identificar a relevância do objetivo proposto. Ainda no capítulo 1 é descrita a metodologia utilizada para se atingir o objetivo, através da qual são definidos os conteúdos dos demais capítulos.

Uma discussão sobre os principais temas tratados no trabalho é apresentada no capítulo 2. Inicialmente, é tratado o tema da reabilitação de edifícios, definindo o termo utilizado de acordo com a abrangência das atividades de intervenção e, em seguida, apresenta-se as principais características e particularidades de uma obra de reabilitação.

Ainda no capítulo 2 são apresentados os conceitos relacionados à sustentabilidade e como estes se aplicam à construção para que, a partir destes e dos conceitos de reabilitação de edifícios, seja discutida a reabilitação com base nos conceitos de sustentabilidade.

No capítulo 3 é descrita a tomada de decisão com base nos conceitos de sustentabilidade. Para tanto, são apresentados os conceitos de tomada de decisão, identificando-se as dificuldades de uma decisão para, então, apresentar um proposta de etapas para o processo de tomada de decisão. 
Conforme a necessidade de se estabelecer requisitos de decisão, os itens 3.2, 3.3 e 3.4 são destinados à identificação dos requisitos de sustentabilidade relevantes ao processo de escolha de tecnologias construtivas para a reabilitação de edifícios, com ênfase nos aspectos ambientais.

Ainda com base no processo de tomada de decisão, conforme a necessidade de se levantar as alternativas de escolha, no capítulo 4 é feito um levantamento de diversas tecnologias que poderão ser consideradas na definição de alternativas para a reabilitação de edifícios.

O capítulo 5 é destinado à discussão da aplicação do processo de tomada de decisão, apresentado no capítulo 3, para a reabilitação de edifícios. Nele, cada etapa do processo é descrita e discutida de acordo com as características da reabilitação de edifícios.

Por fim, no capítulo 6, são apresentadas as considerações finais do trabalho, analisando o atingimento do objetivo proposto, através da metodologia, das propostas e dos resultados obtidos. 


\section{REABILITAÇÃO E SUSTENTABILIDADE DE EDIFÍCIOS}

\section{1 contexto da reabilitação de edifícios}

O esvaziamento de regiões mais antigas das cidades acontece ao mesmo tempo em que novas regiões são ocupadas com grande atividade imobiliária. De modo geral, o centro urbano, caracterizado por seus edifícios do início da urbanização, é abandonado em busca de edifícios mais modernos e que atendam às novas exigências do mercado. Trata-se de um processo natural da dinâmica urbana que, segundo Yolle Neto (2006), tem provocado o deslocamento da produção de edifícios para novos centros, levando, de modo geral, à degradação das áreas centrais.

Possivelmente em decorrência da migração para os novos centros, a cidade de São Paulo, principalmente nas suas áreas centrais, apresenta um parque imobiliário obsoleto, com alta taxa de vacância decorrente, principalmente, do deslocamento do uso dos espaços para outras regiões, das funções e dos ciclos urbanos, do direcionamento da produção imobiliária e da obtenção de renda e lucro na aplicação do capital (BOMFIM, 2004).

A mesma autora, a partir de dados do IBGE, conclui que a cidade de São Paulo apresentou crescimento da taxa de domicílios vagos nas últimas décadas. Em 1991, essa taxa era cerca de $10 \%$ e em 2000 chegava a $12 \%$, estando os edifícios concentrados principalmente nas áreas centrais da cidade. Atualmente, de acordo com dados do mesmo Instituto (IBGE, 2011), esta taxa reduziu para 7,5\%; contudo, ainda se contabilizam 290.317 domicílios vagos na cidade.

Em contrapartida, a área central da cidade de São Paulo possui completa infraestrutura, com acesso por metrô, trens intermunicipais e terminais de ônibus. Segundo o projeto REABILITA (2007), é na área central que se encontram a maior densidade construída, o maior volume de estabelecimentos que originam empregos e de equipamentos culturais e onde ocorre o maior fluxo de pessoas. Portanto, fixar ali um maior número de habitantes contribuiria 
para o desenvolvimento sustentável da cidade como um todo, pois desta forma aproveita-se melhor a infraestrutura instalada.

Dada a idade dos edifícios presentes nesse espaço urbano, faz sentido depreender que a maioria exige algum tipo de intervenção, pois o processo de degradação natural e, muitas vezes, a falta de manutenção de seus subsistemas exigem renovação para o atendimento das demandas dos usuários. O recente projeto lançado pela prefeitura de São Paulo para a desapropriação e reforma de cerca de cinquenta edifícios abandonados no centro da capital, com investimentos da ordem de $R \$ 400.000 .000,00$, tem o objetivo de mudar a característica desta região, transformando parte dos imóveis abandonados em habitação para famílias de baixa renda (MIRANDA, 2010).

Na Europa, segundo Remy (2003), a reabilitação de edifícios passou a despertar o interesse das empresas a partir da década de 1980. Esse autor salienta que até então, o custo da reabilitação superava o de um edifício novo; contudo, o desenvolvimento de tecnologias apropriadas para esse tipo de intervenção fez com se tornasse viável. Em alguns países europeus, o setor de reabilitação possui uma participação significativa na construção de edifícios que, segundo o Euroconstruct (2005), supera o valor gasto com as novas construções.

Nos Estados Unidos, cerca de $30 \%$ dos edifícios habitacionais e comerciais foram construídos antes de 1950 (BUILDING TECHNOLOGY, 2001). De forma geral, segundo o mesmo documento, as cidades americanas possuem áreas centrais antigas e com baixa utilização e um espalhamento urbano para as periferias.

Naquele país, diversas iniciativas nos níveis federal, estadual e municipal foram realizadas com o direcionamento para obras de reabilitação; dentre elas, 0 Nationally Applicable Recommended Rehabilitation Provisions, publicado pelo Departamento de Desenvolvimento Residencial e Urbano (HUD), além de diferentes códigos para a reabilitação de edifícios, como o Uniform Code for 
Building Conservation, desenvolvido em 1985 e o New Jersey Rehabilitation Subcode, em 1998 (BUILDING TECHNOLOGY, 2001).

No Brasil, a atividade de reabilitação é relativamente recente. Trata-se de um país jovem quando comparado aos europeus. Exceto pelos edifícios históricos, seu parque edificado de múltiplos pavimentos para uso corrente data mais expressivamente a partir da década de 1940, concentrando-se ainda mais nas décadas de 1950 e 1960.

Tais edifícios, projetados para um conjunto de necessidades muito diferentes das atuais, passam a exigir alterações, sob pena de, em não ocorrendo, serem abandonados; para que isto seja evitado, intervenções visando à sua reabilitação são necessárias.

Como bem afirmou Aikivouri (1996), os motivos para a reabilitação dos edifícios estão relacionados à sua obsolescência funcional, às necessidades de mudança de uso, à redução de gastos com a sua utilização, além de fatores subjetivos de quem toma a decisão

Na busca da revalorização das regiões onde há concentração de tais edifícios, notadamente no centro das grandes cidades, é que a atividade de reabilitação vem ganhando força no mercado da construção de edifícios. Neste contexto, diversas expressões como reabilitação, retrofit, reforma, dentre outras, começam a fazer parte do vocabulário técnico e, para melhor precisá-las neste trabalho, os principais conceitos são discutidos na sequência.

\subsection{Conceitos ligados à reabilitação}

A reabilitação de edifícios engloba várias atividades relacionadas a uma construção existente. Intervenções voltadas à preservação do patrimônio histórico ou mesmo adaptações de um edifício de uso corrente podem ser realizadas em vários níveis, tanto em pequenas reformas, até na mudança de uso de um edifício de múltiplos pavimentos.

Diferentes termos são utilizados para expressar esse conceito em diferentes países. Na Inglaterra, o termo "refurbishment" é utilizado para qualquer 
intervenção que vise à melhoria de um edifício (SEELEY 1987; EGBU et al., 1998; MANSFIELD, 2002). Por sua vez, alguns autores dos Estados Unidos, Austrália e China, como Cantell (2005); Bullen (2007); Langstone et al. (2008) utilizam o termo "adaptive reuse" para intervenções que visam a mudança de uso do edifício. Outros termos como renovação, transformação, "retrofit", entre outros, são utilizados indistintamente em artigos de revistas e jornais brasileiros.

Na França, o termo mais utilizado é "réhabilitation", como também o é nos Estados Unidos - "rehabilitation". Nesse país, esse termo aparece nos principais documentos relacionados ao assunto, como no "Nationally Applicable Recommended Rehabilitation Provisions" (NARRP), publicado em 1997, e no "New Jersey Rehabilitation Subcode", publicado em 1998 (HUD, 2001).

De acordo com a literatura nacional estudada, o termo Reabilitação de Edifícios é o que mais se adéqua ao contexto do presente trabalho por envolver diversas atividades, tendo sido o adotado, e, por isto, discutido a seguir.

De modo geral, o objetivo das ações visando à reabilitação de um edifício é buscar soluções para danos físicos, patologias e problemas funcionais acumulados ao longo dos anos, ou ainda possibilitar a modernização das instalações e equipamentos existentes, tornando o edifício apto para sua reutilização (AGUIAR et al., 2005). Segundo os autores, a reabilitação pode ainda mudar a função do edifício, seja por intervenções mais profundas, como a reconfiguração dos espaços ou por alterações em grandes áreas.

A reabilitação de um edifício está diretamente ligada ao seu entorno; assim, os elementos de infraestrutura, o desenvolvimento urbano e a dinâmica sócioeconômica são parte fundamental da análise e do processo decisório quanto a reabilitar ou não um edifício (ARANTES, 2001). Portanto, a reabilitação, muitas vezes, deve extrapolar a escala do edifício, devendo ser pensada com foco em todo o ambiente que o cerca, definindo-se, com isto, a reabilitação urbana. Esta tem a finalidade de elevar a qualidade de vida das populações residentes, melhorar as condições físicas de seu parque edificado e os níveis de 
habitabilidade e dotar a área de equipamentos comunitários, infraestrutura, instalações e espaços livres de uso público (AGUIAR et al., 2005).

A reabilitação pode ser entendida como as atividades ou serviços realizados em qualquer propriedade ou conjunto de propriedades que visam estender a vida útil do bem, possibilitando promover edifícios viáveis social e economicamente (SEELEY, 1987).

Marques de Jesus (2008), estudando diferentes propostas de diversos autores e adaptando os conceitos propostos pelo BCSD Portugal (2004), propõe o conjunto de ações pertinentes à reabilitação de edifícios apresentada da Erro! Fonte de referência não encontrada. e define a reabilitação de edifícios como sendo: "uma ação que pode envolver atividades de restauro, manutenção, alteração, retrofit, reparo ou reforma visando dotar o edifício de atributos econômicos ou funcionais equivalentes aos exigidos a um edifício novo para o mesmo fim".

Observa-se, pela proposta da Figura 2.1, que as atividades de restauração, manutenção, alteração, retrofit, reparo e reforma estão inseridas num universo mais amplo: a reabilitação de edifícios que, por sua vez, é parte de uma gama maior de ações que envolve a malha urbana (reabilitação urbana).

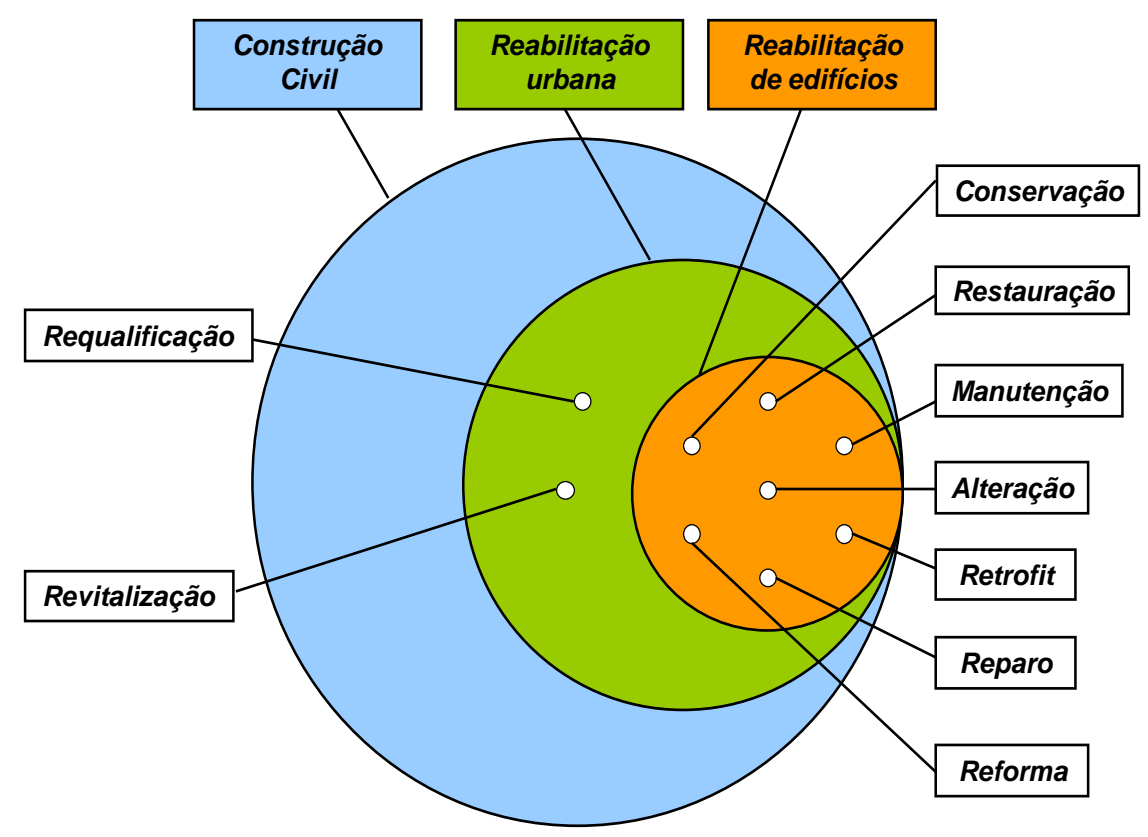

Figura 2.1 - Atividades compreendidas pelo processo de reabilitação de edifícios inseridas na atividade de construção civil. Fonte: MARQUES DE JESUS (2008). 
Analisando-se o conceito de "reabilitação" no âmbito do edifício, são encontradas duas linhas de ação: uma relativa à preservação do patrimônio histórico e outra referente aos demais edifícios. Para a primeira linha têm-se, usualmente, os serviços de restauração, os quais são muito específicos porque buscam conservar os valores estéticos e históricos das edificações através um projeto multidisciplinar, envolvendo pesquisas histórico-documentais, estudos antropológicos e sociológicos, análises dos materiais, das técnicas construtivas empregadas e de suas patologias (KÜHL, 2006). É uma linha de ação destinada principalmente à recuperação de bens que, com o tempo, adquiriram significado cultural. As demais terminologias são mais empregadas para os edifícios sem valor histórico atribuído cuja intervenção não tem o compromisso de recuperar as características originais, mas sim, disponibilizá-lo ao uso novamente, sendo este o foco do presente trabalho.

Seja qual for a modalidade de intervenção visando à reabilitação (restauração, retrofit, reparo, reforma, etc.), o entendimento das características e particularidades do processo de realização da reabilitação é fundamental para o sucesso do empreendimento, sendo este o objeto do próximo item.

\subsection{Características e particularidades do processo de produção da reabilitação}

No projeto REABILITA (2007) foi desenvolvido um fluxograma, apresentado na Figura 2. 2, em que a reabilitação é dividida em quatro grandes fases: diagnóstico do imóvel, projeto, planejamento e gestão da produção, e ocupação do edifício. 


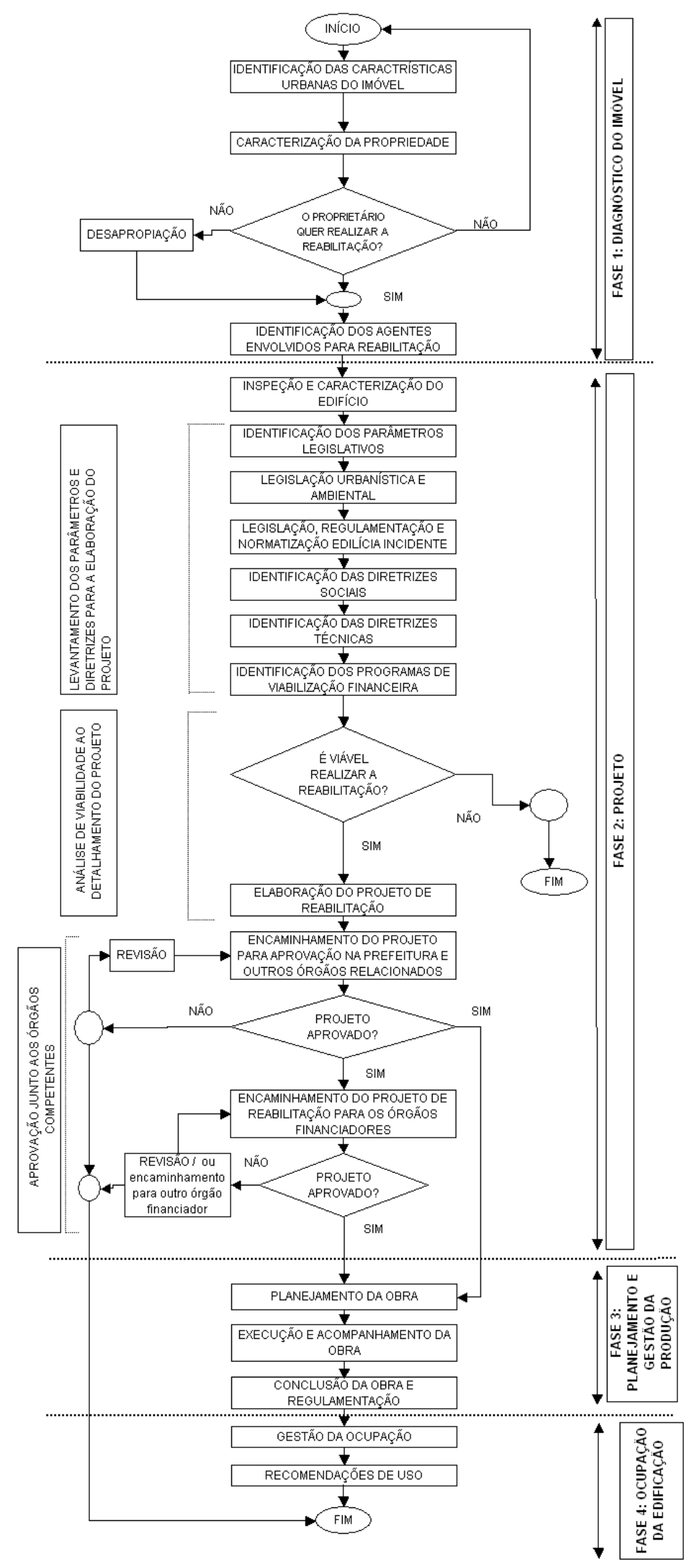

Figura 2. 2 - Fluxograma com as fases da reabilitação. REABILITA (2007) 
Este fluxograma apresenta bem as etapas de diagnóstico e projeto e, através dele é possível entender o processo de reabilitação de um edifício. Contudo, alguns fatores relevantes ao presente trabalho parecem não estar contemplados, como, por exemplo, a interação entre as fases de planejamento e de gestão da produção com as fases de diagnóstico e projeto. Nas obras de reabilitação deve existir uma constante retroalimentação das primeiras etapas enquanto ocorre a execução dos serviços, pois algumas características da construção existente só serão reveladas durante essa etapa. Usualmente, é a partir da demolição, primeiro serviço realizado, que se tem o verdadeiro diagnóstico mais preciso das condições do edifício e a real dimensão dos serviços a serem executados.

Para Yolle Neto (2006) e Marques de Jesus (2008), o processo de produção da reabilitação não está consolidado e, por isto, diversos problemas ocorrem nas obras de reabilitação, de modo particular, falhas de planejamento e trabalhos executados fora da sequência ideal; por consequência, tem-se atrasos, retrabalhos e desperdícios de diversas naturezas (DAOUD, 1997).

Para se identificar as particularidades do processo de reabilitação, apresentamse, na sequência, diversas características - de gestão, de projeto e de execução desse tipo de empreendimento - o que denotará a importância de se tratar a reabilitação como sendo um processo diferenciado, que exige parâmetros próprios os quais ainda precisam ser desenvolvidos e sistematizados.

\subsubsection{Características de gestão}

Ainda que algumas metodologias de análise venham sendo propostas por diversos autores como Lanzinha (2006); Yolle Neto (2006) e pelo Projeto Reabilita (2007), elas não estão consolidadas.

Vários autores caracterizam a construção de um edifício como um sistema complexo devido ao grande número de atividades que estão diretamente relacionadas e interagem entre si. Bertelsen (2003b) apresenta algumas características que aproximam o setor de edificações a um sistema complexo, 
entre elas: o grande número de agentes envolvidos em cada projeto, a não produção em massa, a variação de um projeto para outro, o longo ciclo de vida do produto e o alto custo dos empreendimentos.

Esse mesmo autor destaca que a natureza de um projeto de construção civil baseia-se nas incertezas dos fluxos que alimentam as tarefas que estão sendo executadas. Usualmente, na etapa de planejamento, considera-se a construção como um processo linear, no qual os pacotes de serviços são executados independentemente. Contudo, segundo esse mesmo autor, a visão ordenada dos sistemas é errônea, pois os suprimentos não são idênticos aos especificados no projeto; os recursos e equipamentos supostamente esperam o momento em que serão utilizados; e pequenas incertezas nas atividades podem refletir em incertezas significantes no fluxo como um todo.

O processo de reabilitação de edifícios, além de possuir essas mesmas características, próprias de uma construção nova, apresenta como grande desafio a interação da nova construção com o edifício antigo (EGBU, 1997).

Egbu et al. (1998) desenvolveram um estudo sobre processos e técnicas para a gestão da reabilitação e verificaram que os principais fatores que afetam a eficácia do planejamento são os riscos e incertezas relacionados à falta de informação, a complexidade dos trabalhos e a experiência anterior dos construtores, que necessitam alta especialização. Segundo os autores, na reabilitação o trabalho não é bem planejado e existe dificuldade no controle porque falta um desenvolvimento de métodos que contemplem os fatores acima citados.

Com relação aos riscos e incertezas, além de ações de mitigação e gestão dos riscos, deve-se dar atenção ao processo de comunicação ao longo das etapas de diagnóstico, projeto, planejamento e gestão da produção. March e Simon (1967) afirmam que a capacidade de uma organização manter um padrão de atividade complexo e altamente independente está sujeita, em parte, aos limites de sua capacidade em garantir toda a comunicação exigida pela coordenação de pessoas. 
No caso da reabilitação de edifícios, a comunicação entre os agentes na etapa de execução é fundamental para garantir a produtividade e a qualidade da obra. Devido ao alto nível de imprevisibilidade, à falta de projetos originais do edifício, e às modificações realizadas ao longo de sua utilização, algumas informações necessárias ao projeto são identificadas apenas durante a execução da obra, especialmente na etapa de demolição (EGBU, 1999). A dificuldade de identificação destes fatores na etapa de avaliação (diagnóstico) do edifício intensifica a necessidade de diálogo contínuo do planejamento com a execução. Segundo Roders (2007), durante essa última etapa é comum serem encontradas novas situações que necessitam da intervenção direta das equipes de projeto.

Egbu (1999) coloca a comunicação como um dos principais problemas em obras de reabilitação. Para o autor, os gerentes de canteiro devem estar mais informados sobre as técnicas e métodos considerados no projeto para a realização do empreendimento e os projetistas deveriam ter um melhor entendimento das práticas de construção para que a relação de trabalho pudesse ser mais colaborativa, buscando-se atingir as metas estabelecidas.

O mesmo autor ressalta que para evitar possíveis perdas no processo é necessário elaborar um sistema de comunicação, de forma que os imprevistos sejam rapidamente reconhecidos e uma solução possa ser encaminhada com a mesma brevidade. Para isto, deve ser estabelecido um fluxo de informações que possibilite agilidade na tomada de decisão. Croitor (2008) ressalta que 0 resultado final da reabilitação depende da boa sintonia entre as equipes de projeto e obra e da eficiência da sua comunicação.

Essa exigência de maior interação entre as etapas de projeto, planejamento e execução é resultado da complexidade das obras de reabilitação. Em obras com alto grau de intervenção, pode-se tornar necessária a presença de um "gestor de conflitos" (CROITOR, 2008), responsável por tomar decisões durante a obra e garantir que as informações cheguem ao seu destinatário final sem ruídos. 
Outra característica importante a se considerar na gestão de obras de reabilitação é o fato de que a estrutura do edifício já está pronta, possibilitando, assim, a entrada de várias frentes de serviço ao mesmo tempo (YOLLE NETO, 2006). Esta informação é importante para o planejamento operacional, possibilitando diferentes planos de ataque, de acordo com as características e necessidades de execução do edifício.

A etapa de demolição, por exemplo, por se caracterizar, na maioria das vezes, por uma demolição parcial dos elementos, deve ser executada, empregando-se procedimentos que evitem danos aos elementos a serem mantidos (AGUIAR et al., 2005). Ainda, devido à falta de espaço físico no canteiro e à própria dificuldade de acesso, deve ser dada especial atenção ao controle dos estoques, para que não se comprometa o planejamento da obra (REABILITA, 2007).

Com base nessas características, Egbu (1997) afirma que a implantação de sistemas de gestão para obras de reabilitação deve ser pautada principalmente pela experiência da equipe técnica que, aos poucos, deverá registrá-la de modo que possa ser reproduzida em empreendimentos futuros, consolidando, com isto, a cultura da empresa.

A possibilidade de utilização de diferentes tecnologias construtivas e organizacionais em uma mesma obra exige preparo da mão de obra, para que esta tenha maior flexibilidade de atuação. A formação de um operário polivalente, com o domínio de conhecimento técnico e habilidade profissional em diversas técnicas construtivas, deve ser buscada para atuação neste nicho de mercado. Egbu (1997) destaca que combinar a nova construção com a antiga demanda altos níveis de atividades artesanais e que combinar novos materiais e componentes com os do edifício existente contém uma carga de "armadilhas técnicas". Sendo assim, a mão de obra deve estar preparada para lidar com técnicas novas e antigas para executar os serviços. Segundo Aguiar et al.(2005), é necessário que se tenha o domínio das tecnologias utilizadas na época em que o edifício foi construído e também daquelas que se pretende utilizar na reabilitação. 


\subsubsection{Características de projeto}

Para o desenvolvimento do projeto de reabilitação, o ideal seria que se tivesse como base o projeto do edifício existente. Contudo, como se tratam de edifícios com muitos anos de existência, a usual falta de documentação das informações da época da construção dificulta identificar com exatidão os serviços necessários à reabilitação. Com a falta de projetos originais do edifício e pressupondo modificações realizadas ao longo de sua utilização, o levantamento detalhado do local torna-se não apenas imprescindível, como uma etapa muito mais difícil de ser realizada, uma vez que o diagnóstico deverá ser mais minucioso. Yolle Neto (2006) afirma que a vistoria de campo é fundamental, sendo impossível projetar adequadamente uma obra de reabilitação sem a realização de vistorias cuidadosas dentro do imóvel.

Assim, uma das grandes particularidades do processo de elaboração do projeto de reabilitação é a necessidade de se realizar previamente um diagnóstico preciso do edifício existente (RODERS, 2007). No fluxograma da Figura 2. 2, apresentado pelo projeto REABILITA (2007), analisando-se a etapa de projeto, fica claro que antes da sua elaboração deve-se conhecer as características do imóvel e de seu entorno, além da legislação específica do local em que se situa. O diagnóstico do imóvel, segundo Roders (2007) envolve o levantamento das características da edificação, das possibilidades de adequação e de mudança de uso da edificação e do nível de intervenção necessário para adequar o imóvel ao uso pretendido. Roders e Erkelens (2006) apresentam uma metodologia para o processo de projeto de reabilitação (Figura 2.3) na qual, da mesma forma que o fluxograma apresentado por Reabilita (2007), a etapa de diagnóstico é considerada como uma etapa anterior à elaboração do projeto. Nesta fase, chamada pelos autores de "pre-design", o projetista analisa toda a informação documental, oral e física existente. As informações encontradas devem ser organizadas e sintetizadas para que o projetista possa realizar uma avaliação consciente do ambiente do edifício, da importância do imóvel e valores culturais identificados e das condições de conservação do mesmo. 


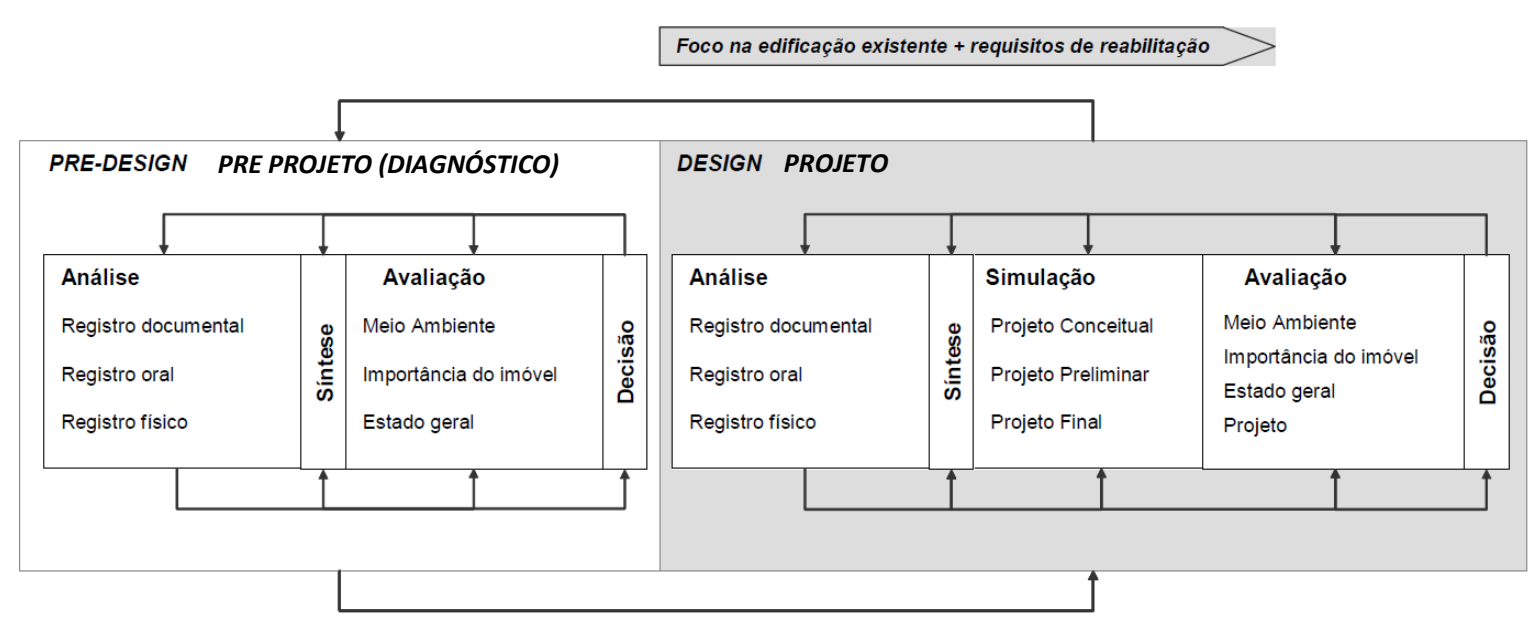

Figura 2.3 - Modelo de processo de projeto para a reabilitação de edifícios (Roders, 2006. Tradução de Croitor, 2008)

A etapa de diagnóstico do imóvel existente, específica do projeto de reabilitação, é considerada por Aguiar et al. (2005), Roders (2007) e Croitor (2008) como uma etapa crucial do processo de produção, sendo que falhas nessa etapa certamente resultarão em problemas posteriores.

Aguiar et al. (2005) consideram que o diagnóstico do edifício deva ser iniciado por meio de uma análise detalhada dos problemas existentes no edifício. De acordo com esses autores, as análises devem se desenvolver sob diversos pontos de vista, abordando aspectos históricos, arquitetônicos e construtivos, podendo ser necessário aos projetistas o estudo da "cultura da edificação original". Destacam, ainda, a necessidade de articular os resultados desse levantamento com os de um estudo de novas possibilidades técnicas, buscando-se, desta forma, encontrar as soluções mais adequadas para substituir materiais, componentes e tecnologias originais.

Yolle Neto (2006), por sua vez, considera que o diagnóstico deva ocorrer ao longo de toda etapa de projeto, realizando-se uma avaliação inicial das condições em que se encontram os subsistemas do edifício e, em uma segunda etapa, um detalhamento dos problemas patológicos, por meio de um mapeamento de cada elemento. Essa atividade envolveria um número maior de profissionais porquanto seriam necessários especialistas em cada área do conhecimento. 
A partir da análise dos elementos ou partes da construção, seja por meio de análises ou ensaios no local ou em laboratório, poderá ser identificado o estado, as capacidades e características essenciais dos materiais, componentes e elementos existentes, permitindo prever a amplitude da intervenção, bem como, os custos envolvidos.

No diagnóstico são identificados os elementos da construção que poderão ser reaproveitados na reabilitação e aqueles que deverão ser removidos ou substituídos. Aguiar et al. (2005) enfatizam a durabilidade das construções antigas e afirmam que se deve promover a máxima utilização possível dos diversos elementos e partes da construção antiga, antes de prever a sua substituição por materiais e soluções tecnológicas mais modernas. Segundo os autores, essa opção é justificada pelas dificuldades de compatibilização entre as antigas e novas tecnologias construtivas. Mesmo com a análise do edifício e a elaboração de um diagnóstico detalhado, incertezas podem prejudicar a elaboração do projeto. De acordo com REABILITA (2007), situações como: a presença de elementos estruturais não constantes do projeto original; a presença de alvenaria resistente em alguns elementos de fechamento, considerados inicialmente apenas com a função de vedação, impossibilitando remoções sem novos escoramentos; elementos em pior situação do que o verificado no diagnóstico inicial são exemplos de imprevistos que surgem somente durante a execução.

A dificuldade de identificação dessas situações na etapa de avaliação (diagnóstico) do edifício intensifica a necessidade de diálogo contínuo entre a equipe de projeto com a de execução; além disso, exige também que a atividade de projeto seja mantida praticamente durante toda a etapa de execução, pois, segundo Roders (2007), nessa etapa é comum serem encontradas novas situações que necessitem da intervenção das equipes de projeto.

\subsubsection{Características da execução e dos métodos construtivos}

Apesar das semelhanças com a obra nova, o processo de produção de reabilitação usualmente apresenta algumas atividades distintas, como a 
demolição de parte dos subsistemas do edifício que, muitas vezes, pode ser significativa. Em contrapartida, dependendo do nível de intervenção, pode-se eliminar algumas etapas, como por exemplo, a de execução da estrutura ou mesmo parte dos vedos, as quais têm implicações importantes tanto no custo quanto no prazo de execução do empreendimento. Marques de Jesus (2008), em um estudo em que analisou cinco empreendimentos de reabilitação da cidade de São Paulo, verificou que, em dois deles, não houve gastos com a produção da estrutura; em dois outros este gasto foi muito baixo. Em apenas um dos empreendimentos, em que parte da circulação foi ampliada em estrutura metálica, o custo da estrutura esteve próximo de $12 \%$ do custo direto da obra.

A atividade de demolição, mesmo parcial, não é comumente realizada na construção de um edifício novo. As demolições normalmente ocorrem quando existe alguma edificação no terreno a ser construído que deva se totalmente retirada, o que usualmente é realizado antes do início do empreendimento. $\mathrm{Na}$ reabilitação de edifícios, ao contrário, esta é uma atividade presente na quase totalidade empreendimentos, visto que a maioria dos edifícios a serem reabilitados necessita da retirada de elementos como esquadrias internas, revestimentos, vedos, sistemas prediais, dentre outros. Isto pode ser verificado nos estudos de caso apresentados por Yolle Neto (2006), Croitor (2008) e Marques de Jesus (2008), em que todos os empreendimentos apresentaram atividades de demolição.

O impacto gerado pela demolição pode ser considerado em diversos aspectos. Além do custo referente à demolição, à limpeza e ao transporte do entulho (estimado, por Marques de Jesus (2008) em torno de $5 \%$ do custo direto nas obras por ele analisadas), há também o volume de resíduos gerados que deve ser considerado e que corresponde a cerca de $55 \%$ do total de resíduos sólidos urbanos (JOHN et al., 2006). Esta etapa causa, também, impactos no entorno, em relação ao ruído e à geração de material particulado, podendo ainda comprometer a integridade das edificações vizinhas (REABILITA, 2007). 
Poon (1997) apresenta um método de "demolição seletiva", que consiste na segregação de materiais antes e durante o processo de demolição, evitando a contaminação de materiais inertes com madeira, plástico ou metal. A demolição seletiva deve seguir o caminho contrário do processo de construção - ou seja, de cima para baixo - e suas etapas devem ser definidas de acordo com 0 planejamento de cada obra.

Outro problema é o relacionado a imperfeições com relação às características geométricas (prumo, esquadro, nivelamento) de partes do edifício que serão reaproveitadas (Aguiar et al., 2005). Os procedimentos de execução devem contemplar alternativas para que a construção nova relacione-se da melhor forma possível com a antiga, estabelecendo-se previamente os níveis máximos de aceitação destas irregularidades. A vedação é um dos principais subsistemas a sofrer intervenções em empreendimentos de reabilitação, seja devido à grande interatividade com os demais subsistemas do edifício ou também pela comum reorganização dos espaços nas intervenções (REABILITA, 2007). No estudo de caso apresentado por Yolle Neto (2006) pode-se verificar a necessidade de recuperação de componentes das vedações internas e externas, como esquadrias de portas e janelas. Segundo Roders (2007), nas intervenções em elementos de vedação devem ser aplicados componentes de forma a proporcionar flexibilidade na adaptação aos espaços existentes, rapidez na execução, e que não sobrecarreguem a estrutura existente.

Além dos métodos construtivos tradicionais, é comum em obras de reabilitação o reforço estrutural para adequar o edifício às novas solicitações. Nesta atividade deve se levar em conta a estrutura existente, a tecnologia utilizada para o reforço, além das interfaces entre eles e os demais subsistemas (AGUIAR et al., 2005). Segundo o autor, as soluções das intervenções de reforços estruturais podem ser: a substituição de elementos defeituosos; o aumento da dimensão das seções; a adição de elementos de outras naturezas; ou a alteração da distribuição de esforços. 
Os sistemas prediais, conforme constatado por Marques de Jesus e Barros (2010), são de extrema importância na composição dos custos da reabilitação. Isto porque, nestes edifícios antigos, os sistemas prediais são substituídos por sistemas que se adaptem às novas condições de uso (REABILITA, 2007). Na etapa de execução, deve-se considerar os elementos estruturais existentes, que geram interferências na passagem das tubulações e dificultam seu encaminhamento (MARQUES DE JESUS e BARROS, 2008).

O projeto REABILITA (2007) propõe uma solução para as instalações hidráulicas, pela execução de "kits hidráulicos", que seriam posicionados e fixados na parede existente.

As características e particularidades apresentadas demonstram a necessidade de se desenvolver métodos e processos construtivos específicos para as obras de reabilitação, pois nem sempre um procedimento empregado para uma obra nova é adequado à realidade da reabilitação e a viabilidade de um empreendimento deste tipo está diretamente ligada à definição de métodos construtivos específicos e adequados à realidade da reabilitação.

Essa afirmativa é corroborada por Remy (2003), Yolle (2006) e Marques de Jesus (2008), que consideram que o desenvolvimento do setor está diretamente ligado ao uso de novas tecnologias que incorporem o desenvolvimento de materiais e componentes adequados às especificidades desse tipo de obra.

A escolha das tecnologias a serem empregadas no processo de reabilitação deve considerar a compatibilidade com a construção existente. Segundo Roders e Erkelens (2006), um fator importante a ser considerado pelos projetistas de reabilitação é a ligação entre as tecnologias existentes e as novas. Os autores afirmam que as interfaces muitas vezes são inevitáveis, no entanto essa ligação poderá ser planejada pelos projetistas, por exemplo, com juntas secas ou por sistemas de encaixe, podendo-se obter um maior aproveitamento da construção existente.

Apresentadas as características e particularidades da reabilitação, para se atingir o objetivo proposto no presente trabalho, é necessário entender como a 
reabilitação pode ser realizada com base nos conceitos de sustentabilidade, sendo esse o foco do item 2.4.

\subsection{Sustentabilidade na construção}

Grande parte das atividades humanas que impactam no meio ambiente tem ligações com a indústria da construção civil, responsável por importante parcela do consumo global de recursos e geração de resíduos (CIB, 2002; HOLNESS, 2009).

Tanto economicamente quanto com relação ao consumo de materiais e recursos energéticos, a construção de edifícios é responsável por uma parcela significativa do impacto gerado ao meio ambiente desde a construção, até o fim da vida útil do edifício, passando por toda fase de uso e operação (ARAÚJO, 2009).

Por isto, diferentes agentes - governos, consumidores, investidores, sindicatos e associações - têm alertado, estimulado e pressionado o setor da construção a incorporar práticas sustentáveis nas suas atividades (CÂMARA DA INDÚSTRIA DA CONSTRUÇÃO, 2008).

O conceito de sustentabilidade foi difundido, inicialmente em 1987, pelo World Commission on Environment and Development, da Organização das Nações Unidas, que publicou o texto "Nosso futuro comum" (Brundtland, 1987). Esse documento, conhecido por relatório Brundtland, em referência à Gro Harlem Brundtland, presidente da comissão, define desenvolvimento sustentável como sendo o:

"desenvolvimento econômico e social que atenda às necessidades da geração atual sem comprometer a habilidade das gerações futuras atenderem às suas próprias necessidades”.

O Department of Trade and Industrie (DTI, 2006), do Reino Unido, considera que um dos princípios da estratégia para o desenvolvimento sustentável é o respeito aos limites ambientais do planeta, incluindo recursos naturais e 
biodiversidade, com o objetivo de melhorar o ambiente e garantir que os recursos naturais necessários para a vida estejam disponíveis para as futuras gerações.

Segundo o relatório Brundtland (1987), o desenvolvimento sustentável é um processo de mudança no qual a exploração dos recursos, a orientação dos investimentos e os rumos do desenvolvimento tecnológico estariam de acordo com as necessidades atuais e futuras. Publicações posteriores, como a Agenda 21 global (ONU, 1992) e a Agenda 21 brasileira (BRASIL, 2004) adotam esse mesmo conceito para o desenvolvimento de suas atividades.

A partir da Agenda 21 global (ONU, 1992), diversos setores identificaram a necessidade de se buscar o desenvolvimento sustentável. Em 1999, o Conselho Internacional para a Pesquisa e Inovação em Construção (CIB) publicou a Agenda 21 para a Construção Sustentável (CIB, 1999), com o intuito de adaptar os conceitos de desenvolvimento sustentável ao ambiente construído e ao setor da Construção Civil. Nesse documento, a construção sustentável é definida como sendo:

"o processo holístico para restabelecer e manter a harmonia entre os ambientes natural e construído e criar estabelecimentos que confirmem a dignidade humana e estimulem a igualdade econômica".

De acordo com o CIB (1999), o "processo holístico" deve considerar todo o ciclo de vida do edifício. Isto implica na gestão do ambiente construído, buscando minimizar os impactos gerados desde a concepção do edifício considerando os impactos da produção dos materiais e componentes que serão utilizados - sua execução, operação e manutenção até a sua desconstrução.

Buscar uma indústria da construção "mais sustentável" é buscar fornecer mais valor, poluir menos, ajudar no uso sustentado de recursos, responder mais efetivamente às partes interessadas e melhorar a qualidade de vida presente sem comprometer o futuro (SILVA, 2003). Além disso, deve atender às 
necessidades dos usuários, ser economicamente viável para seus investidores e ser produzido com técnicas que reduzam o trabalho degradante e inseguro feito pelo homem (CEOTTO, 2008).

O conceito de sustentabilidade é, portanto, complexo, pois envolve a redução dos impactos nos âmbitos social, econômico e ambiental (BRE, 2001).

A sustentabilidade social é uma resposta às necessidades das pessoas envolvidas, em todo o processo produtivo (desde o planejamento até a desconstrução), com a satisfação dos clientes e usuários pelo trabalho em conjunto com clientes, fornecedores, funcionários e comunidades locais.

A sustentabilidade deve permitir, ainda, a viabilidade econômica pelo uso mais eficiente de recursos, incluindo mão de obra, materiais, água e energia.

A sustentabilidade ambiental implica na prevenção de impactos perigosos e potencialmente irreversíveis pelo uso cuidadoso de recursos naturais, pela minimização dos resíduos, pela proteção e, quando possível, pela melhora do meio ambiente;

Portanto, o balanço desses três aspectos deve combinar o atendimento às necessidades dos seres humanos com a capacidade de recursos existentes no planeta (CIB 2002).

Silva (2003), o DTI (2006) e a Câmara da Indústria da Construção (2008) destacam alguns dos princípios básicos da construção sustentável, principalmente quanto ao seu aspecto ambiental:

- reduzir o impacto gerado durante a construção e a operação, valorizando as características originais do entorno;

- maximizar o desempenho do edifício durante todo o seu ciclo de vida;

- executar um projeto que seja flexível, para se adequar às necessidades atuais e futuras dos usuários;

- utilizar matérias-primas que contribuam com a ecoeficiência do edifício; 
- reduzir o consumo energético e de água;

- reduzir, reutilizar, reciclar e dispor corretamente os resíduos sólidos;

- fazer uso de modernas tecnologias construtivas que melhorem a eficiência do edifício e reduzam os impactos ambientais na etapa de construção do edifício;

- proporcionar meios de educação ambiental: conscientização dos envolvidos no processo;

De acordo com o CIOB (200-?), para uma construção ambientalmente sustentável deve-se considerar quatro elementos-chave envolvidos na construção civil: materiais, resíduos, poluição e energia.

Ao propor uma metodologia de avaliação do grau de sustentabilidade de edifícios, Degani (2009) salienta a importância de se tratar a sustentabilidade da construção ao longo de todo o ciclo de vida do edifício. E, analisando dados referentes aos custos totais ao longo das fases do ciclo de vida, a autora compartilha a idéia de que os impactos ambientais e sociais ocorrem na mesma proporção destes custos. Ceotto (2008), analisando os custos envolvidos na produção e operação de edifícios corporativos, conclui que a produção participa com somente $20 \%$ deles, enquanto $80 \%$ é relativo à etapa de uso e operação; conclui, portanto, que a maior parcela de impactos gerados no meio ambiente ocorre nessa etapa.

Tal afirmativa é sustentada por estudos relacionados ao consumo energético de edifícios. Na fase operacional, dependendo do tipo de utilização e considerando um ciclo de vida de mais de 50 anos, o consumo de energia pode chegar a $80 \%$ do consumo total que inclui a energia consumida na construção e demolição, além da energia incorporada nos materiais (WORLD BUSINESS COUNCIL FOR SUSTAINABLE DEVELOPMENT, 2009b).

De acordo com Lamberts et al. (1997), a eficiência energética pode ser entendida como a obtenção de um serviço com baixo dispêndio de energia. Portanto, segundo esse autor, "um edifício é energeticamente mais eficiente 
que outro quando proporciona as mesmas condições ambientais com um menor consumo de energia".

De acordo com o World Business Council for Sustainable Development (2009a), a eficiência energética dos edifícios está condicionada a fatores como:

- Redução da demanda de energia: por utilizar equipamentos que sejam mais eficientes; e

- Produção local de energia: a partir de fontes renováveis.

O conceito de eficiência energética aplicado aos edifícios pode proporcionar grandes reduções no consumo de energia. Um estudo do Instituto Mckinsey (ENKVIST et al., 2007) estimou que medidas de redução da demanda podem reduzir pela metade o crescimento esperado na procura por eletricidade em todo o mundo.

O Fourth Assessment Report do Painel Intergovernamental para as Alterações Climáticas (IPCC, 2007) estima que em 2020 as emissões de $\mathrm{CO}_{2}$, a partir da utilização de energia em edifícios, poderão ser reduzidas em $29 \%$, apenas com melhorias tecnológicas que aumentem sua eficiência energética.

Lamberts et al. (1997) já ressaltavam que o consumo de energia poderia ser reduzido significativamente se os arquitetos e engenheiros tivessem mais conhecimento sobre os conceitos de eficiência energética e os aplicassem quando da realização do projeto ou especificação de materiais e equipamentos. Segundo esses autores, os materiais de construção têm uma forte influência sobre as condições de conforto do ambiente interior. A especificação dos materiais exige o entendimento de suas propriedades e de sua adequação às características do projeto. O uso de isolamento térmico ou proteção solar em paredes, janelas e telhados, o tipo de telha e o tipo de vidro empregados devem ser estudados a fim de se evitar perdas ou ganhos térmicos excessivos e obter melhorias de conforto no interior.

Corroborando a idéia anterior, Holness (2009) afirma que a Indústria da Construção Civil pode contribuir com a redução do consumo global de energia 
e da emissão de gás carbônico na atmosfera aumentando a eficiência energética dos edifícios. Contudo, segundo esse autor, grande parte desse consumo de energia provém dos edifícios existentes, que não foram concebidos com base nos conceitos de sustentabilidade. Portanto, a busca da eficiência energética não pode apenas ser considerada nos projetos de edifícios novos, mas também na melhoria das instalações dos edifícios construídos. Ou seja, buscar a sustentabilidade de edifícios passa, necessariamente, pela reabilitação daqueles hoje construídos (HOLNESS, 2009; WILKINSON e REED, 2008), sendo, por isso, o tema do item a seguir.

\subsection{A reabilitação de edifícios com base nos conceitos de sustentabilidade}

Historicamente, a indústria da construção tem reposto edifícios antigos por meio de novas construções (SALMON, 2004). Contudo, mais recentemente, a busca pela sustentabilidade ambiental tem levado a que o estoque de edifícios ganhe importância junto aos agentes do setor da construção civil (HOLNESS, 2009). O Engenheiro Luiz Henrique Ceotto, em entrevista a um periódico paulista (O ESTADO DE SÃO PAULO, 2010) afirma que "edifício sustentável é edifício econômico" e considera que o emprego de recursos sustentáveis deve levar a uma economia nos gastos com energia e água. Além disso, destaca que, no Brasil, os edifícios comerciais com essas características possuem menor taxa de vacância em relação aos demais, e, nos Estados Unidos, maior valor de locação e taxas de seguro cerca de $10 \%$ menores.

Nos Estados Unidos, o consumo de energia elétrica nos edifícios residenciais e comerciais corresponde a cerca de $40 \%$ de toda a oferta; com isso, eles são responsáveis por mais de um terço do total das emissões de $\mathrm{CO}_{2}$ na atmosfera (HOLNESS, 2009).

Com estes dados, Holness (2009) destaca a importância de se buscar a sustentabilidade ambiental por meio de intervenções nos edifícios existentes, mais do que no desenvolvimento de tecnologias para edifícios novos. Possivelmente por haver essa tendência, a atividade de construção de novos edifícios tem diminuído em países desenvolvidos, correspondendo, 
anualmente, a apenas 2,0\% do estoque existente (BULLEN, 2007; HOLNESS, 2009).

Segundo Bullen (2007), além de possibilitar a redução do consumo de energia, a reabilitação estende a vida útil do edifício e por consequência, os recursos utilizados na sua construção são aproveitados por mais tempo, o que também garante a redução de impactos ambientais.

Diversos autores analisam a viabilidade de se reabilitar um edifício considerando as atuais exigências de sustentabilidade. De acordo com Wilkinson e Reed (2008), as razões para se reabilitar edifícios podem ser agrupadas em quatro categorias: social, ambiental, econômica e tecnológica. Estas razões são aqui analisadas de acordo com as categorias propostas pelos autores.

\subsubsection{Social}

Os edifícios existentes representam um valor social e cultural importante para cada localidade, pois representam a memória da época em que foram construídos. Entretanto, é inevitável que, com o passar do tempo, as convenções sociais mudem e, como resultado, alguns edifícios percam seu valor original de uso no ambiente em que estão inseridos, sendo necessária a mudança do propósito a que se destinava (WILKINSON e REED, 2008). A reabilitação, na visão de Ball (1999), é uma maneira de preservar o capital sócio-cultural, assim como, a memória de um povo.

Bullen (2007) afirma que a reabilitação pode: criar recursos valiosos para a comunidade a partir de propriedades improdutivas; reduzir substancialmente a utilização de novos terrenos; evitar a expansão urbana; diminuir os custos de construção; e revitalizar regiões. Acrescenta-se que a menor expansão urbana traz, por consequência, menor necessidade de investimentos em infraestrutura, como pavimentação de vias, expansão de redes de transporte coletivo, entre outros. Este é um aspecto destacado também por Bonfim (2004); Yolle Neto (2006) e Cotelo (2008). 


\subsubsection{Ambiental}

O aspecto ambiental da sustentabilidade é intrínseco ao processo de reabilitação, uma vez que esta demanda menor quantidade de material, pois parte dele provém da construção original que é aproveitada. O simples aproveitamento de parte do edifício existente resulta em redução nas atividades de extração, transformação e transporte de recursos naturais, além da redução dos resíduos gerados (BULLEN, 2007; JOHNSTONE, 1996).

Em um estudo realizado por Itard e Klunder (2007), comparou-se o impacto ambiental entre diferentes níveis de intervenção para dois casos típicos de reabilitação urbana nas cidades de Delft e Haia, na Holanda. A ferramenta utilizada para esta análise foi a EcoQuantum, v. 2.00, uma ferramenta de ACV (avaliação do ciclo de vida) para avaliar os efeitos ambientais de edifícios em relação a uso de materiais, consumo de energia, consumo de água, e impactos ambientais, entre eles: esgotamento dos recursos abióticos, aquecimento global e destruição da camada de ozônio. De acordo com os autores, uma vantagem imediata da reabilitação foi a minimização dos resíduos. Além disto, ressaltam que, em relação a novas construções, a reabilitação gasta menos energia e utiliza menos material.

Normalmente, a melhoria do desempenho energético ocorre como resultado de uma estratégia de reforma realizada com outros objetivos, como substituição de equipamentos antigos por outros mais modernos, ou readequação dos ambientes a novas necessidades de uso; porém, de acordo com Kohler e Hassler (2002), nos últimos anos os estudos explorando o estoque imobiliário já têm considerado tópicos relacionados especificamente ao consumo de energia, além de perdas, fluxo de materiais, impactos ambientais e preservação de recursos.

Os mesmos autores citam que, na Alemanha, a redução do consumo energético era considerada apenas com relação ao aquecimento dos edifícios, mas que, a partir da década de 1980, começa a se considerar o consumo de eletricidade e também a produção de $\mathrm{CO}_{2}$ (KOHLER e HASSLER, 2002). 
Os edifícios comerciais têm sido identificados como contribuintes para o aquecimento global durante seu ciclo de vida, devido à grande quantidade de emissão de $\mathrm{CO}_{2}$ (WILKINSON e REED, 2008). Nesse contexto, a reabilitação se torna uma alternativa, tanto para a melhoria de desempenho, como para o conforto dos ambientes, além de contribuir com a melhoria da eficiência energética dos edifícios. Os autores citam, além da redução do uso de materiais e recursos, a possibilidade de melhoria na gestão da água, visando à redução do seu consumo, e a melhoria da eficiência energética, como ações eficientes para a obtenção da sustentabilidade ambiental de um edifício.

\subsubsection{Econômico}

Do ponto de vista econômico, diversos estudos avaliam a reabilitação como uma alternativa em relação à demolição e reconstrução de um edifício, seja residencial, comercial ou industrial. Johnstone (1996) observa que os custos do setor residencial podem ser mais baixos quando comparados com uma nova construção. Bullen (2007), em seu estudo sobre a reabilitação na Austrália, também discute a viabilidade econômica para edifícios comerciais. Ball (1999), que analisa o setor industrial do Reino Unido, também considera a reabilitação como melhor alternativa econômica.

No entanto, Wilkinson e Reed (2008) discutem que ao se avaliar entre a reabilitação e a demolição seguida de construção, deve-se considerar o nível de intervenção à qual o edifício deve ser submetido, considerando, principalmente, o estado em que se encontra e a qualidade da construção original. Os autores destacam que, em alguns casos, quando a estrutura do edifício se encontra danificada e necessita de reparos importantes - como quando há corrosão de armaduras - o nível de intervenção pode ser alto e inviabilizar economicamente a reabilitação.

Assim, a simples reabilitação só é possível quando a qualidade dos imóveis existentes é suficiente para satisfazer às novas necessidades. De acordo com Itard e Klunder (2007), por este motivo, na maioria dos distritos urbanos dos Países Baixos, as construções foram demolidas em larga escala e foram realizadas obras novas. 
No Brasil, Marques de Jesus (2008) estudou os custos da reabilitação de edifícios para habitação de interesse social e concluiu que esses custos variam em função de diversos fatores, como necessidades dos empreendedores, características dos projetos e condições impostas pela legislação vigente. Além destes fatores, a complexidade da obra de reabilitação é determinante nos custos de produção. Desta forma, a viabilidade de se reabilitar um edifício deve ser analisada caso a caso, de acordo com as condições de conservação e necessidades de transformação do edifício existente.

Uma clara conclusão do estudo dos autores anteriormente citados é que, considerando-se as exigências de sustentabilidade, a reabilitação é mais eficiente do que a demolição e execução de novo edifício. Entretanto, Itard e Klunder (2007) destacam que a transformação tem de ser possível, o que implica que o edifício tem de ter certo grau de flexibilidade para valer a pena mantê-lo, ao invés de se optar por um novo. Além disto, fatores como a vida útil residual dos elementos a serem mantidos devem ser avaliados.

\subsubsection{Tecnológico}

De acordo com Vijverberg (2002), uma das razões para que se realize a reabilitação é a constante mudança tecnológica que ocorre, o que leva os edifícios a se tornarem obsoletos em curto espaço de tempo. A funcionalidade ou utilidade do espaço em termos de distribuição física, qualidade dos serviços, telecomunicação e sistemas de informação, sistemas de climatização e eficiência energética são todos fatores importantes que influenciam na percepção de valor de mercado do edifício. Por estas razões, um edifício pode estar em boas condições físicas, mas não atender às necessidades requeridas pelo mercado e, em consequência, ficar ocioso ou com valor reduzido de locação por obsolescência funcional (WILKINSON e REED, 2008).

De acordo com Casagrande Jr. (2005), as tecnologias recentes buscam maximizar o uso da informação para proporcionar ao usuário facilidade e conforto empregando sistemas automatizados. Contudo, segundo o autor, a crescente demanda por conforto pode ser incompatível com a sustentabilidade. $\mathrm{O}$ uso de sistemas de aquecimento e resfriamento, assim como outros 
sistemas que consomem energia, são fatores que podem melhorar o conforto do usuário, mas podem não ser sustentáveis. Por esta razão as tecnologias têm um importante papel na redução do consumo de energia quando utilizadas para automatizar os sistemas e otimizar o consumo energético do edifício.

O desenvolvimento de novas tecnologias, que reduzam o consumo de recursos ou gastos com a operação, podem, consequentemente, aumentar a exigência dos usuários. Desta forma, uma tecnologia corrente pode se tornar obsoleta após o surgimento de uma nova tecnologia, mais eficiente. Pode-se dar como exemplo as esquadrias de aço, que em edifícios residenciais foram substituídas por esquadrias mais leves, como alumínio e PVC, com as mesmas características de vida útil e estanqueidade.

Hatkopf e Loftness (1999) consideram que, devido às mudanças tecnológicas, os edifícios e seus sistemas devem permitir a constante melhoria de suas tecnologias. De acordo com os autores, o desempenho da construção depende dos seguintes fatores: satisfação do usuário, flexibilidade e adaptabilidade tecnológica e otimização do uso de recursos.

Os mesmos autores afirmam que as tecnologias típicas dos edifícios de hoje, devem ser modificadas para atender à nova infraestrutura de serviço. Ainda segundo os mesmos, para o atendimento às exigências dos usuários, novas tecnologias e novos conceitos para planejamento dos espaços devem considerar aspectos como a qualidade térmica do ambiente, obtida através de equipamentos de controle de temperatura; a ventilação e qualidade do ar; iluminação natural e qualidade visual; distribuição interna e possibilidades de reorganização dos espaços; e conectividade de dados. Deste modo, novas tecnologias a serem aplicadas em um edifício existentes devem ser orientadas para atender ao usuário final.

\subsection{Considerações finais}

De acordo com as idéias apresentadas nesse item, os princípios de sustentabilidade hoje vigentes têm se tornado um fator chave para 0 
desenvolvimento da indústria da construção de edifícios e cada vez mais deverá influenciar na necessidade de se renovar seu parque edificado.

O debate acerca do desenvolvimento sustentável focado no ambiente construído tem estimulado políticos, proprietários de edifícios, projetistas, construtores e a indústria da construção em geral a considerar o estoque existente como um importante capital físico, econômico, social e cultural (KOHLER, 2002).

Bullen (2007), a partir de um estudo realizado com a aplicação de questionários para gestores de projetos, destaca os benefícios da reabilitação que suportam os princípios da sustentabilidade:

- Redução do consumo de recursos, do uso de energia e de emissões;

- Aumento da vida útil dos edifícios;

- Maior eficiência financeira do que demolição e reconstrução;

- Aproveitamento da energia incorporada por um tempo maior;

- Criação de recursos para a comunidade a partir de uma propriedade improdutiva;

- Valorização do entorno;

- Redução da utilização de novos terrenos e da expansão urbana.

Segundo Wilkinson e Reed (2008), apesar das recentes demandas social, ambiental e tecnológica relacionadas à sustentabilidade, o fator econômico continua sendo o principal argumento na tomada de decisão entre reabilitar um edifício antigo e construir um novo.

Partindo-se do entendimento de que a viabilidade econômica da reabilitação está também relacionada às tecnologias que serão empregadas no edifício existente, a escolha da melhor alternativa sobre que tecnologias utilizar é fundamental ao processo decisório. Dessa forma, a melhor alternativa deve ser aquela que proporciona um maior benefício em relação a todos os requisitos de 
sustentabilidade relacionados a um menor custo. Ou seja, a relação custo benefício sempre será um balizador na tomada de decisão.

Contudo, mensurar os benefícios não é uma atividade simples, visto a complexidade das atividades de reabilitação, mencionadas anteriormente, além da dificuldade de se quantificar os ganhos relacionados a cada um dos requisitos. Por isso, entende-se ser fundamental seguir um método que possa estruturar o processo decisório, podendo-se garantir a escolha da melhor alternativa.

O capítulo a seguir trata do processo de tomada de decisão que, no contexto do presente trabalho, terá a sustentabilidade ambiental como premissa para a análise das tecnologias construtivas voltadas à reabilitação. 


\section{A SUSTENTABILIDADE COMO BASE PARA A TOMADA DE DECISÃO}

\subsection{Tomada de decisão}

Para Clemen (1991), uma boa decisão não é a que fornece necessariamente o melhor resultado e sim a que é tomada a partir do entendimento do problema e de uma cuidadosa análise dos assuntos importantes. Os resultados, por outro lado, podem ser positivos ou negativos, independentes da qualidade da decisão.

Ehrlich (1996a) considera que boa decisão é o melhor que se pode fazer e bom resultado é o que se deseja obter, ou seja, o melhor que se pode esperar. A obtenção do melhor resultado está baseada, em parte, na tomada de uma boa decisão, e é também afetada pela aleatoriedade introduzida no processo de decisão pelas incertezas ambientais.

Simon (1957), já afirmava que não existe solução certa ou errada. As decisões podem ser melhores ou piores, pois são avaliadas no sentido relativo, de acordo com os objetivos estabelecidos. De acordo com esse autor "a decisão ou escolha é o processo pelo qual uma alternativa, adequada a um determinado momento, é selecionada e realizada". Portanto, a tomada de decisão não envolve apenas 0 ato final de escolha entre alternativas, mas 0 processo como um todo.

Um processo de decisão começa pela identificação do que se deseja (objetivo a ser alcançado), do que se pode fazer (alternativas que permitam alcançar o objetivo) e da informação de que se dispõe (elementos que suportam a decisão) (item 3.1.2).

Espera-se que estes elementos, ordenados numa estrutura lógica, resultem na melhor decisão possível (EHRLICH, 1996a). Contudo, como bem pondera Graeml (2004), a melhor decisão, ou seja, aquela que atinge o resultado ideal, exigiria um conhecimento absoluto de todos os fatores e condições que afetam o objeto sobre o qual se está decidindo e suas inter-relações. Isto nem sempre 
é possível; portanto, trata-se da decisão ótima, a partir dos elementos de que se dispõe.

\subsubsection{Dificuldades e limitações na tomada de decisão}

Cada decisão a ser tomada envolve dificuldades provenientes de quatro fontes básicas (Clemen, 1991):

- Complexidade: características, como incertezas existentes; diferentes valores de cada grupo envolvido; distintos caminhos a se seguir e de campos para se agir; aspectos econômicos, entre outros, podem resultar em enorme complexidade para a tomada de decisão. Considerar todas as variáveis ao mesmo tempo é muito difícil. Deve-se, então, buscar métodos efetivos para organizar problemas complexos em uma estrutura que possa ser analisada.

- Múltiplos objetivos: o decisor pode estar interessado em múltiplos objetivos; porém, o progresso em uma direção pode impedir o progresso nas demais. Neste sentido, o decisor deve analisar os benefícios e custos para cada objetivo definido. Através de estrutura e ferramentas específicas para lidar com múltiplos objetivos pode-se obter uma visão mais ampla do sistema.

- Pessoas envolvidas com diferentes perspectivas: podem dificultar o processo de decisão, pois cada perspectiva pode levar a diferentes conclusões. Mesmo sob uma perspectiva única, pequenas mudanças em algumas entradas podem levar a diferentes escolhas. Esta dificuldade é particularmente pertinente quando mais de uma pessoa está envolvida no processo de tomada de decisões. Diferentes indivíduos tendem a olhar para o problema de diferentes perspectivas, discordando nas incertezas e no valor das várias saídas.

- Incertezas: É um dos maiores problemas na tomada de decisão. Para minimizá-los, as incertezas devem ser identificadas e representadas de forma quantitativa para aumentar a clareza no processo decisório. Segundo Bernstein (1997), a adoção de uma abordagem probabilística, 
que considere as chances de diversos possíveis cenários se configurarem, ajuda a obter um controle maior sobre as situações às quais necessitam de tomada de decisão.

As dificuldades, muitas vezes, estão ligadas a fatores limitantes que podem prejudicar $\mathrm{o}$ processo de tomada de decisão e às expectativas sobre 0 resultado (GRAEML, 2004). De acordo com esse mesmo autor, os principais fatores limitantes são a percepção do indivíduo, o nível de informação, a lógica da satisfação e a redução das alternativas por interferência política, os quais são aqui brevemente discutidos.

\subsubsection{Percepção do indivíduo}

A tomada de decisão depende da percepção do indivíduo que estabelece referências a situações anteriormente vivenciadas. Em função do grau de percepção, pode-se ou não limitar o espectro de alternativas e impedir uma análise mais abrangente, pois o decisor, consciente ou inconscientemente, seleciona somente uma parte da situação e não sua totalidade (FIOL, 2001).

Para Robbins (1999), o que alguém percebe pode ser substancialmente diferente da realidade objetiva. Portanto, as decisões são tomadas com base na percepção que o decisor tem da realidade e não na realidade em si. Destaca, ainda, que o foco da atenção das pessoas é influenciado por seus interesses pessoais, o que contribui para que as pessoas desenvolvam uma percepção seletiva do que acontece à sua volta. O mesmo autor salienta que a percepção do indivíduo também é influenciada pela situação, ou seja, o contexto em que uma decisão está sendo tomada é importante e contribui para que se opte por uma determinada alternativa em detrimento de outras consideradas menos ajustadas à situação.

\subsubsection{Nível de informação}

A quantidade e o tipo de informação disponível para a tomada de decisão é mais um fator que afeta diretamente o resultado final. Por melhores que sejam os sistemas de informação utilizados, a informação plena exigiria, além do 
conhecimento completo da situação atual, o conhecimento também da situação futura.

Contudo, segundo Fiol (2001), os custos marginais para a obtenção de mais informações são crescentes, enquanto seu valor marginal para aprimoramento da decisão é decrescente. Isto significa que uma quantidade excessiva de informações pode ser prejudicial para a tomada de decisão, pois a capacidade de se estudar e combinar um grande número de dados é limitada.

Para Bernstein (1997), o excesso de informações, ou mesmo a existência de informações irrelevantes para a decisão atrapalha o processo, fazendo com que as pessoas sejam menos racionais em suas escolhas. $O$ autor cita que 0 ser humano parece ter dificuldade de levar em consideração, simultaneamente, um número elevado de fatores e elencá-los em ordem de importância.

\subsubsection{Lógica da satisfação}

Existe sempre uma meta pré-estabelecida para os resultados mínimos esperados. Simon (1957) observa que as pessoas se contentam com soluções que satisfaçam suas necessidades mínimas, não procurando a solução ótima, se isto exigir esforço adicional. O mesmo autor observa que a alternativa escolhida usualmente não permite a realização completa ou perfeita dos objetivos visados, representando apenas a melhor solução encontrada naquelas circunstâncias.

\subsubsection{Redução das alternativas por interferência política}

O processo de decisão pode ser afetado por forças externas que podem limitar a disponibilidade de opções e forçar uma alternativa diferente da que seria escolhida (GRAEML, 2004).

De acordo com Graeml (2004), em todas as situações de decisão vão existir interesses em jogo e o gerenciamento dos interesses individuais.A tentativa de alinhá-los da melhor forma possível aos interesses da organização colocam os decisores constantemente em situações em que precisam optar por soluções 
de consenso ou de compromisso, que não seriam as escolhidas em um processo decisório isento de tais interferências.

\subsubsection{O processo de tomada de decisão}

O processo da tomada de decisão envolve a escolha da melhor alternativa levando em conta múltiplos critérios, fatores ou objetivos, tais como o custo, o impacto ambiental, ou os riscos associados a cada uma destas alternativas.

O propósito do processo de decisão é ajudar o decisor a pensar sistematicamente sobre problemas complexos e melhorar a qualidade do resultado das decisões (CLEMEN, 1991).

Para Shimizu (2006), o primeiro passo na direção da tomada de decisão é a formulação do problema, pois uma formulação inadequada do problema leva a um resultado que reduz a eficiência e a eficácia, já que a formulação incorreta pode definir o problema errado.

Autores como Simon (1957), Monks (1985); Clemen (1991), Ehrlich (1996a) e Souza (2003) sugerem que o processo de tomada de decisão seja dividido em etapas. Esses autores desenvolveram metodologias de tomada de decisão, as quais são apresentadas a seguir.

Para Simon (1957) o processo de tomada de decisões é composto por quatro etapas principais. Inicialmente, segundo o autor, deve-se partir de uma necessidade de decisão, formular as alternativas para, então, avaliá-las. Por fim, de ser feita a escolha de uma ou mais alternativas.

Para Clemen (1991), o processo de tomada de decisão consiste nas etapas apresentadas na Figura 3.1 em que se observa que além das quatro etapas apresentadas por Simon (1957), Clemen (1991) considera ainda a realização de uma análise de sensibilidade e a implementação da alternativa escolhida. 


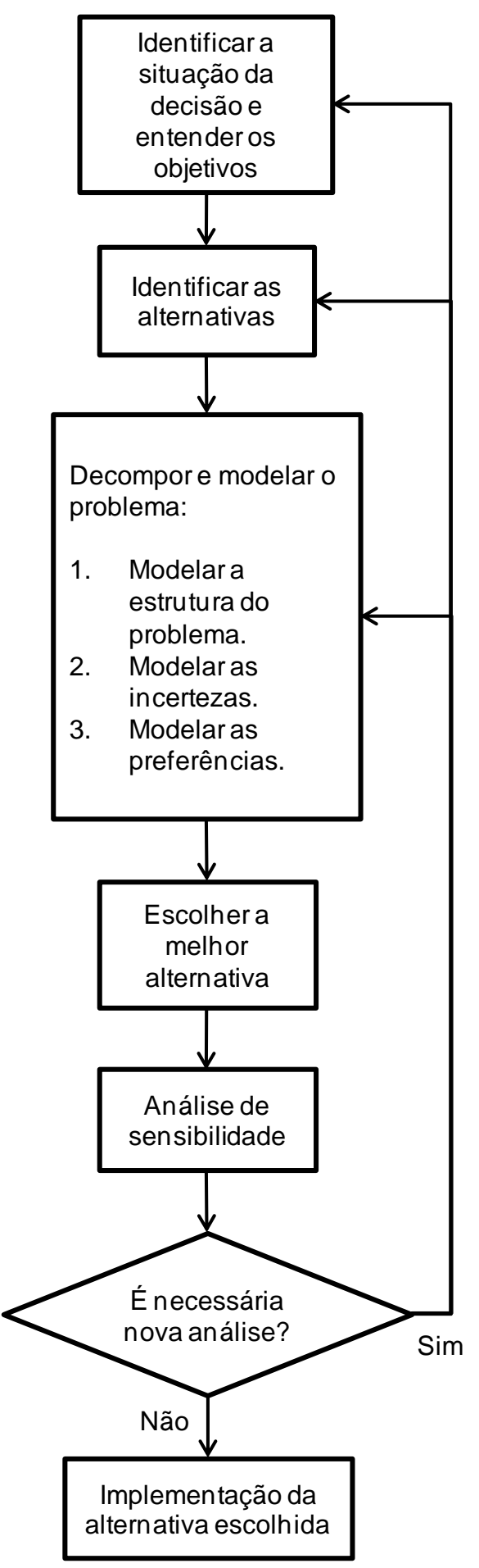

Figura 3.1 - 0 processo de decisão segundo Clemen (1991).

Ehrlich (1996b) define etapas e sub-etapas para o processo de decisão. Para o autor, a primeira etapa do processo é a formulação da decisão, na qual, além 
de definir o que se deseja decidir, são levantadas todas as informações para que se possa tomar a decisão. Essas informações consistem no levantamento das alternativas e das incertezas. Além disso, nessa etapa deve-se limitar o escopo do problema e eliminar os fatores irrelevantes.

$\mathrm{Na}$ etapa seguinte, a análise determinística, deve-se obter um modelo, de forma que se possa identificar e eliminar as alternativas dominadas, concentrando-se apenas nas variáveis sensíveis, através de uma análise de sensibilidade. Além da análise determinística, Ehrlich (1996b) propõe que seja feita uma análise probabilística, que inclui a obtenção de informações sobre as incertezas relacionadas às variáveis sensíveis e construção de um modelo da árvore de decisão.

$\mathrm{Na}$ última etapa o autor considera que se deve determinar a política ótima pelo valor esperado, analisar o risco pela distribuição cumulativa e calcular o valor da informação.

De acordo com Monks (1985), o processo de decisão se divide em duas fases. A formulação, na qual o problema é definido, os critérios são estabelecidos e são geradas alternativas; e a tomada de decisão, que consiste em avaliar as alternativas e escolher a que melhor atende aos objetivos, além de implementar a decisão e monitorar os resultados.

Souza (2003) propõe um método de tomada de decisão dividido nas fases de formulação do problema, formulação da decisão e implantação. Essas fases, por sua vez, estão divididas nas seguintes etapas:

- Identificar qual é o problema da decisão e os objetivos;

- Identificar quais são as alternativas para se conseguir os objetivos;

- Selecionar quais critérios as alternativas devem atender;

- Estabelecer qual a importância relativa de cada critério a partir dos objetivos;

- Avaliar as alternativas segundo esses critérios; 
- Escolher a alternativa que melhor atende a esse grupo de critérios, segundo a avaliação efetuada;

- Aprovação;

- Implantação.

As metodologias de tomada de decisão acima apresentadas são resumidas no Quadro 3.1, de forma que se possa compará-las conforme as etapas definidas em cada uma delas.

De acordo com os processos apresentados no Quadro 3.1, verifica-se que todos possuem etapas em comum, como a definição do problema de decisão, definição de alternativas e seleção. Ainda, a etapa de definição dos critérios de escolha é apresentada por Monks (1985) e Souza (2003), através da qual os autores buscam definir como as diferentes alternativas devem ser comparadas. Clemen (1991) e Ehrlich (1996b) incluem no processo uma etapa de modelagem, para a comparação das alternativas, e, nesta etapa, consideram a necessidade de critérios de comparação para a definição da melhor alternativa.

A partir da análise e comparação das propostas identificadas anteriormente, a Figura 3.2 apresenta um fluxograma síntese com as etapas que, se acredita, devam fazer parte de um processo de tomada de decisão e que será utilizada para a escolha de tecnologias construtivas para a reabilitação de edifícios (capítulo 5). 


\begin{tabular}{|c|c|c|c|c|c|}
\hline 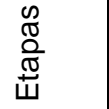 & Simon (1957) & Monks (1985) & Clemen (1991) & Ehrlich (1996a) & Souza (2003) \\
\hline 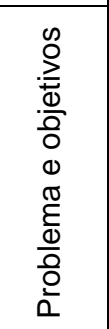 & $\begin{array}{l}\text { - Percepção da necessidade de } \\
\text { decisão ou oportunidade; }\end{array}$ & $\begin{array}{l}\text { - Definir o problema e suas } \\
\text { variáveis relevantes } \\
\text { (parâmetros); } \\
\text { - Estabelecer os objetivos; }\end{array}$ & $\begin{array}{l}\text { - Identificação da situação de } \\
\text { decisão e entendimento dos } \\
\text { objetivos. }\end{array}$ & $\begin{array}{l}\text { - Definir o que se deseja decidir; } \\
\text { - Estabelecer o que se deseja } \\
\text { obter; } \\
\text { - Listar as incertezas; } \\
\text { - Limitar o escopo do problema e } \\
\text { eliminar os fatores irrelevantes; } \\
\text { - Construir um diagrama de } \\
\text { influências. }\end{array}$ & $\begin{array}{l}\text { Formulação do problema: } \\
\text { - Identificar qual é o problema da } \\
\text { decisão e os objetivos; }\end{array}$ \\
\hline 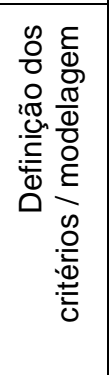 & & $\begin{array}{l}\text { - Relacionar os parâmetros com } \\
\text { os objetivos, ou seja, modelar o } \\
\text { problema; } \\
\text { - Gerar as alternativas de } \\
\text { decisão e as alternativas dos } \\
\text { cenários possíveis, para } \\
\text { diferentes valores dos } \\
\text { parâmetros; }\end{array}$ & $\begin{array}{l}\text { - Decomposição e modelagem } \\
\text { do problema }\end{array}$ & $\begin{array}{l}\text { Análise determinística: } \\
\text { - Obter um modelo; } \\
\text { Análise probabilística: } \\
\text { - Obter as informações sobre as } \\
\text { incertezas; } \\
\text { - Identificar as sensíveis; } \\
\text { - Construir o modelo da árvore } \\
\text { de decisão. }\end{array}$ & $\begin{array}{l}\text { - Selecionar quais critérios as } \\
\text { alternativas devem atender } \\
\text { - Estabelecer qual a importância } \\
\text { relativa de cada critério a partir } \\
\text { dos objetivos; }\end{array}$ \\
\hline 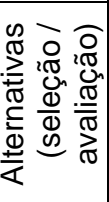 & $\begin{array}{l}\text { - Formulação de alternativas de } \\
\text { ação; } \\
\text { - Avaliação das alternativas em } \\
\text { termos de suas contribuições }\end{array}$ & $\begin{array}{l}\text { - Avaliar as alternativas e } \\
\text { escolher a que melhor satisfaz } \\
\text { aos objetivos; }\end{array}$ & - Identificação das alternativas & $\begin{array}{l}\text { - Listar as alternativas; } \\
\text { - Eliminar as alternativas } \\
\text { dominadas; } \\
\text { - Fazer análise de sensibilidade; } \\
\text { - Avaliação }\end{array}$ & $\begin{array}{l}\text { - Identificar quais são as } \\
\text { alternativas para se conseguir } \\
\text { estes objetivos; } \\
\text { - Avaliar as alternativas segundo } \\
\text { esses critérios; }\end{array}$ \\
\hline 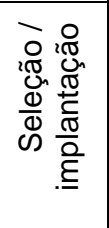 & $\begin{array}{l}\text { - Escolha de uma ou mais } \\
\text { alternativas para fins de } \\
\text { execução }\end{array}$ & $\begin{array}{l}\text { - Implementar a decisão e } \\
\text { monitorar os resultados por meio } \\
\text { de análise de sensibilidade e } \\
\text { aprendizagem, com } \\
\text { retroalimentação dos resultados } \\
\text { para a melhoria do modelo. }\end{array}$ & $\begin{array}{l}\text { - Escolha da melhor alternativa } \\
\text { - Análise de sensibilidade e } \\
\text { implementação }\end{array}$ & Apresentação dos resultados & $\begin{array}{l}\text { - Escolher a alternativa que } \\
\text { melhor atende a esse grupo de } \\
\text { critérios; } \\
\text { - Aprovação; } \\
\text { - Implantação. }\end{array}$ \\
\hline
\end{tabular}

Quadro 3.1 - Etapas do processo de decisão. 


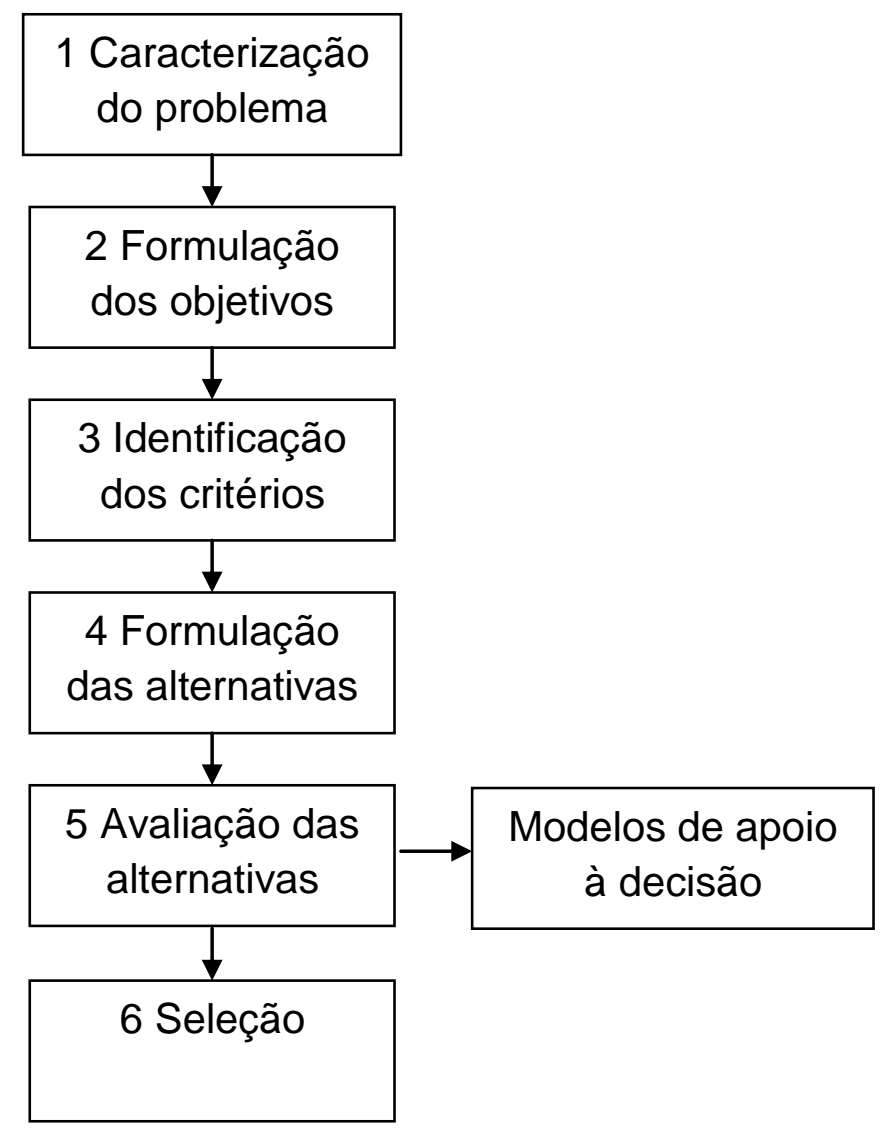

Figura 3. 2 - Fluxograma do processo de tomada de decisão.

\subsubsection{Modelos como ferramenta de apoio à decisão}

A maioria das decisões não requer o auxílio de modelos, mas, quando a decisão é importante, complexa, envolve muitas alternativas e distintos objetivos, necessita ser compartilhada por um grupo de pessoas ou envolve riscos, um modelo pode servir de grande apoio (EHRLICH, 1996a).

Segundo Ehrlich (1996b), um modelo é uma representação simplificada da realidade e deve permitir reproduzir os elementos da realidade envolvida que sejam os mais importantes para a decisão e, com ele, deverá ser possível: analisar distintos cenários, obter subsídios para a tomada de decisão ou verificar a estabilidade dos resultados de uma análise, no caso de uma análise de sensibilidade. 
Os métodos e modelos aplicáveis aos processos de decisão podem ser classificados em duas categorias: os usados para formular e estruturar as alternativas de decisão, como é o caso da modelagem BIM (Building Information Modeling) ou do programa Energy Plus, e os que selecionam a melhor decisão (SHIMIZU, 2006).

Para Ehrlich (1996b), os elementos de um modelo são:

- Variáveis de controle ou de decisão: sobre as quais se pode atuar para atingir os objetivos;

- Variáveis de estado ou da natureza: sobre as quais não se tem controle, mas que afetam as consequências ou resultados de uma decisão;

- Estrutura do modelo: no âmbito do estudo, corresponde a equações matemáticas que combinam as relações no modelo.

- Parâmetros: valores numéricos que entram nas equações;

- Critérios de decisão ou preferências;

- Objetivos ou metas.

Ainda para esse autor, a utilização de modelos para o apoio às decisões traz benefícios, como: identificar os elementos relevantes para a decisão e descartar os irrelevantes; educar a intuição; analisar situações complexas; analisar muitas alternativas; e analisar a estabilidade dos resultados.

Decisões com certo grau de complexidade e importantes no que se refere às suas consequências ou aos riscos envolvidos não podem se basear em um único critério. Existem vários fatores a serem considerados e a importância relativa de cada um deles deve ser estudada para que um não seja ocultado por outros. Neste caso, os modelos multicritério de decisão podem ser utilizados como importantes ferramentas (BERNSTEIN, 1997).

Para o desenvolvimento destes modelos, diversos métodos de apoio à decisão foram criados para auxiliar o decisor a comparar, classificar e escolher uma dentre as diversas alternativas. Basicamente, estes métodos trabalham com a 
mesma ferramenta principal, a matriz de decisão (SALOMON e MONTEVECHI, 1999). O Quadro 3.2 representa a matriz de decisão utilizada em uma situação em que se deseja analisar três alternativas de acordo com cinco critérios diferentes. Na matriz de decisão, segundo Salomon e Montevechi (1999), os aij representam o desempenho das alternativas $i$ segundo os critérios $j$.

\begin{tabular}{|l|c|c|c|c|c|}
\hline & Critério 1 & Critério 2 & Critério 3 & Critério 4 & Critério 5 \\
\hline Alternativa 1 & $a_{11}$ & $a_{12}$ & $a_{13}$ & $a_{14}$ & $a_{15}$ \\
\hline Alternativa 2 & $a_{21}$ & $a_{22}$ & $a_{23}$ & $a_{24}$ & $a_{25}$ \\
\hline Alternativa 3 & $a_{31}$ & $a_{32}$ & $a_{33}$ & $a_{34}$ & $a_{35}$ \\
\hline
\end{tabular}

Quadro 3.2 - Modelo de matriz de decisão (SALOMON e MONTEVECHI, 1999).

Dos diversos métodos existentes, Schimidt (1995) Erlich (1996b), Souza (2003), destacam:

- MAUT (Multi-attribute utility theory)

- AHP (Analytic hierarchy process)

- MCDA (multi criteria decision aid)

- MACBETH (Measuring Attractiveness by a Categorical Based Evaluation Technique)

No presente trabalho, será abordado o método AHP, pois este considera critérios qualitativos e quantitativos, e se adéqua às características das decisões para a utilização de tecnologias na reabilitação de edifícios. Segundo Ehrlich (1996a), é um método simples de modelagem e permite a compreensão do decisor na estruturação do problema. A desvantagem do método, segundo 0 autor é o rigor teórico do método. Entendendo as limitações do método e adaptando-o às necessidades do decisor, o mesmo autor considera esta uma boa ferramenta de apoio às decisões. 


\subsubsection{O método AHP (Analytic hierarchy process)}

O AHP é um método de análise de decisão e planejamento de múltiplos critérios desenvolvido por Thomas L. Saaty (1991). Desde então, tem se mostrado uma metodologia variada e útil, fornecendo a cientistas de diferentes áreas subsídios para a tomada de decisão. Em 1998, foi publicada a ASTM E 1765 (1998), que define um padrão para a aplicação da AHP em decisões de investimentos relacionados a edifícios e seus sistemas.

De acordo com Schimidt (1995), a teoria reflete a maneira pela qual a mente humana conceitualiza e estrutura um problema complexo. O método natural de funcionamento da mente humana segundo Saaty (1991), quando se defronta com um grande número de elementos que abrangem uma situação complexa, é agregá-los em grupos, segundo propriedades comuns. Assim, o conceito do método AHP é decompor a complexidade encontrada.

O método caracteriza-se pela capacidade de analisar um problema de tomada de decisão, através da construção de níveis hierárquicos, ou seja, para se ter uma visão global da relação complexa inerente à situação, o problema é decomposto em fatores. Os fatores são decompostos em um novo nível de fatores, e assim por diante. Esses elementos, previamente selecionados, são organizados numa hierarquia descendente em que os objetivos finais devem estar no topo, seguidos de seus sub-objetivos, imediatamente abaixo, partindo do geral para o mais particular e concreto (SCHIMIDT, 1995).

Segundo Souza (2003), a AHP consiste de três etapas para a solução do problema:

- Estruturação (Decomposição) da hierarquia;

- Determinação dos julgamentos comparativos;

- Classificação das alternativas. 


\subsubsection{Estruturação da hierarquia}

Uma hierarquia é uma estrutura simples, usada para representar o tipo de dependência de um nível ou componente de um sistema com outro de maneira sequencial (SCHIMIDT, 1995).

A partir do objetivo e da definição dos critérios, estes são estruturados de forma hierárquica para que se possa identificar o grau de importância de cada critério. Como uma regra geral, a hierarquia é desenvolvida do geral (nível superior) para o particular (níveis inferiores) ou da incerteza para maior certeza. No AHP os fatores são selecionados e arranjados, em uma estrutura hierárquica descendente do objetivo geral para o critério, subcritério e alternativas em níveis sucessivos. A Figura 3. 3 representa a estrutura hierárquica básica para a tomada de decisão.

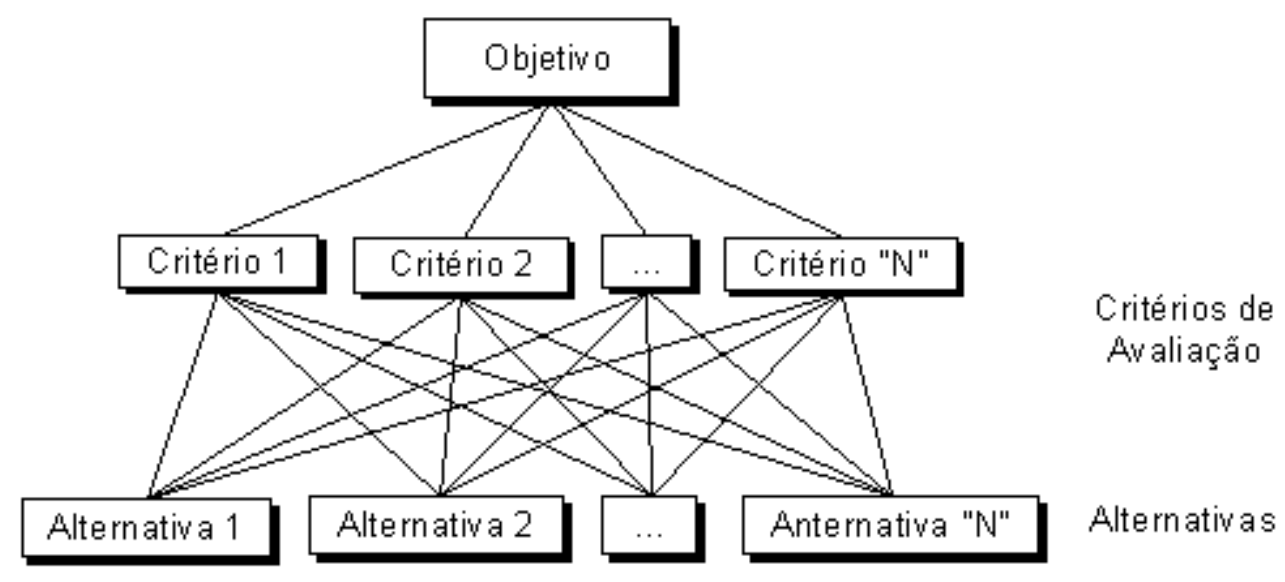

Figura 3. 3 - Estrutura hierárquica básica (SCHIMIDT, 1995).

Cada critério, segundo Saaty (1991), pode ser dividido em subcritérios que, na estrutura hierárquica, localizam-se abaixo dos critérios, conforme a Figura 3. 4. 


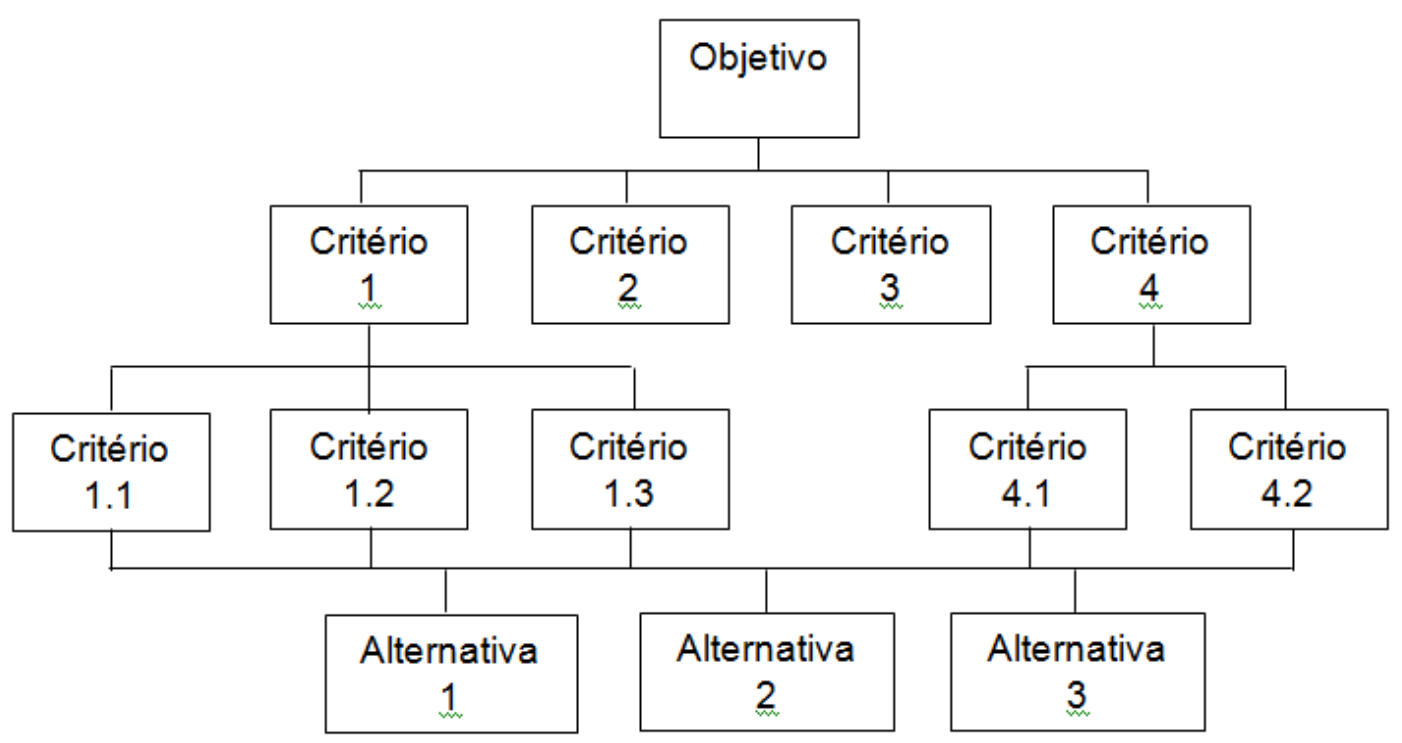

Figura 3. 4 - Níveis de hierarquia (SAATY, 1991).

\subsubsection{Determinação dos julgamentos comparativos}

A determinação dos julgamentos comparativos é feita para que se possa identificar o grau de importância de cada critério, ou seja, é a forma de ponderação dos critérios utilizada no método AHP.

Esta ponderação é feita para cada nível da hierarquia, comparando os critérios entre si, aos pares através de uma Matriz de Comparação Paritária (MCP). Exemplos de MCP para os critérios do nível 1 e nível 2 (mostrados na Figura 3. 4), estão apresentados no Quadro 3.3, Quadro 3.4 e Quadro 3.5.

\begin{tabular}{|c|c|c|c|c|}
\hline & Critério 1 & Critério 2 & Critério 3 & Critério 4 \\
\hline Critério 1 & 1 & & & \\
\hline Critério 2 & & 1 & & \\
\hline Critério 3 & & & 1 & \\
\hline Critério 4 & & & & 1 \\
\hline
\end{tabular}

Quadro 3.3 - MCP para os critérios do nível 1. 


\begin{tabular}{|l|c|c|c|}
\hline & Critério 1.1 & Critério 1.2 & Critério 1.3 \\
\hline Critério 1.1 & 1 & & \\
\hline Critério 1.2 & & 1 & \\
\hline Critério 1.3 & & & 1 \\
\hline
\end{tabular}

Quadro 3.4 - MCP para os critérios do nível 2, relacionados ao critério 1.

\begin{tabular}{|c|c|c|}
\hline & Critério 4.1 & Critério 4.2 \\
\hline Critério 4.1 & 1 & \\
\hline Critério 4.2 & & 1 \\
\hline
\end{tabular}

Quadro 3.5 - MCP para os critérios do nível 2, relacionados ao critério 4.

Para o preenchimento da MCP, o decisor deve comparar a importância que um critério possui em relação a outro, de acordo com uma escala de comparações. A ASTM E 1765 (1998) estipula níveis de comparação dentre alternativas, classificando-os de 1 a 9.

- 1- Igualmente preferível;

- 3 - Moderadamente preferível;

- 5 - Fortemente preferível;

- 7 - Muito fortemente preferível;

- 9 - Extremamente preferível.

A ASTM E 1765 (1998) considera que os valores de 2, 4, 6, 8 são valores intermediários. De acordo com o documento, os valores da MCP caracterizam a importância do critério da linha em relação ao critério da coluna, conforme mostrado no Quadro 3.6. Dessa forma, se o critério 1 é fortemente preferível ao critério 2, o valor de $a_{12}$ é 5 e, consequentemente, o valor de $a_{21}$ é 1/5.

Saaty (1991) fez experiências com várias escalas $(3,5,7,9,20)$, e concluiu que a escala de nove valores fornece flexibilidade suficiente para diferenciar dois 
elementos. Embora, o autor não impeça a utilização de outras escalas de julgamento.

\begin{tabular}{|c|c|c|c|c|c|}
\hline & $\begin{array}{c}\text { Critério } \\
1\end{array}$ & $\begin{array}{c}\text { Critério } \\
2\end{array}$ & $\begin{array}{c}\text { Critério } \\
3\end{array}$ & $\ldots$ & $\begin{array}{c}\text { Critério } \\
\mathrm{n}\end{array}$ \\
\hline $\begin{array}{c}\text { Critério } \\
1\end{array}$ & 1 & $\begin{array}{c}\text { Crit. } 1 \\
\text { versus } \\
\text { Crit.2 }\end{array}$ & $\begin{array}{c}\text { Crit. } 1 \\
\text { versus } \\
\text { Crit.3 }\end{array}$ & $\ldots$ & $\begin{array}{c}\text { Crit. } 1 \\
\text { versus } \\
\text { Crit.n }\end{array}$ \\
\hline $\begin{array}{c}\text { Critério } \\
2\end{array}$ & $\begin{array}{c}\text { Crit. } 2 \\
\text { versus } \\
\text { Crit.1 }\end{array}$ & 1 & $\begin{array}{c}\text { Crit. } 2 \\
\text { versus } \\
\text { Crit.3 }\end{array}$ & $\ldots$ & $\begin{array}{c}\text { Crit. } 2 \\
\text { versus } \\
\text { Crit.n }\end{array}$ \\
\hline $\begin{array}{c}\text { Critério } \\
3\end{array}$ & $\begin{array}{c}\text { Crit. } 3 \\
\text { versus } \\
\text { Crit.1 }\end{array}$ & $\begin{array}{c}\text { Crit. } 3 \\
\text { versus } \\
\text { Crit.2 }\end{array}$ & 1 & $\ldots$ & $\begin{array}{c}\text { Crit. } 3 \\
\text { versus } \\
\text { Crit.n }\end{array}$ \\
\hline$\ldots$ & $\ldots$ & $\ldots$ & $\ldots$ & 1 & $\ldots$ \\
\hline $\begin{array}{c}\text { Critério } \\
\mathrm{n}\end{array}$ & $\begin{array}{c}\text { Crit. } n \\
\text { versus } \\
\text { Crit.1 }\end{array}$ & $\begin{array}{c}\text { Crit. } n \\
\text { versus } \\
\text { Crit.2 }\end{array}$ & $\begin{array}{c}\text { Crit. } n \\
\text { versus } \\
\text { Crit.3 }\end{array}$ & $\ldots$ & 1 \\
\hline
\end{tabular}

Quadro 3.6 - Preenchimento da MCP (adaptado de ASTM E 1765, 1998)

Após preenchidos os valores das MCP para os critérios dos vários níveis, calcula-se as prioridades relativas. Este cálculo compreende dividir cada valor da tabela pela soma da respectiva coluna, e então obter a média de cada linha, conforme o Quadro 3.7.

\begin{tabular}{|c|c|c|c|}
\hline & $\begin{array}{c}\text { Critério } \\
1\end{array}$ & $\begin{array}{c}\text { Critério } \\
2\end{array}$ & $\begin{array}{c}\text { Critério } \\
3\end{array}$ \\
\hline $\begin{array}{c}\text { Critério } \\
1\end{array}$ & $\mathrm{a}_{11}$ & $\mathrm{a}_{12}$ & $\mathrm{a}_{13}$ \\
\hline $\begin{array}{c}\text { Critério } \\
2\end{array}$ & $\mathrm{a}_{21}$ & $\mathrm{a}_{22}$ & $\mathrm{a}_{23}$ \\
\hline $\begin{array}{c}\text { Critério } \\
3\end{array}$ & $\mathrm{a}_{31}$ & $\mathrm{a}_{32}$ & $\mathrm{a}_{33}$ \\
\hline $\begin{array}{c}\text { Total } \\
\text { col. }\end{array}$ & $\begin{array}{c}\mathrm{a}_{41}= \\
\sum\left(\mathrm{a}_{11}: \mathrm{a}_{31}\right)\end{array}$ & $\sum\left(\mathrm{a}_{12}: \mathrm{a}_{32}\right)$ & $\sum\left(\mathrm{a}_{13}: \mathrm{a}_{33}\right)$ \\
\hline
\end{tabular}

\begin{tabular}{|c|c|c|c|}
\hline $\begin{array}{c}\text { Critério } \\
1\end{array}$ & $\begin{array}{c}\text { Critério } \\
2\end{array}$ & $\begin{array}{c}\text { Critério } \\
3\end{array}$ & Ponderação \\
\hline $\mathrm{a}_{11} / \mathrm{a}_{41}$ & $\mathrm{a}_{12} / \mathrm{a}_{42}$ & $\mathrm{a}_{13} / \mathrm{a}_{43}$ & $\begin{array}{c}\mathrm{p}_{1}=\text { média } \\
\text { da linha }\end{array}$ \\
\hline $\mathrm{a}_{21} / \mathrm{a}_{41}$ & $\mathrm{a}_{22} / \mathrm{a}_{42}$ & $\mathrm{a}_{23} / \mathrm{a}_{43}$ & $\begin{array}{c}\mathrm{p}_{2}=\text { média } \\
\text { da linha }\end{array}$ \\
\hline $\mathrm{a}_{31} / \mathrm{a}_{41}$ & $\mathrm{a}_{32} / \mathrm{a}_{42}$ & $\mathrm{a}_{33} / \mathrm{a}_{43}$ & $\begin{array}{c}\mathrm{p}_{3}=\text { média } \\
\text { da linha }\end{array}$ \\
\hline 1 & 1 & 1 & 1 \\
\hline
\end{tabular}

Quadro 3.7 - Esquema para determinação das MCP para os critérios (adaptado de Souza, 2003). 
Este cálculo é feito para cada nível de critérios, respeitando sua hierarquia. Então, este mesmo cálculo é feito para as alternativas, avaliando as alternativas em relação a cada critério separadamente.

\subsubsection{Classificação das alternativas}

Por fim é feita a classificação das alternativas de acordo com os critérios ponderados. Para isso, multiplica-se os valores das ponderações dos critérios pelos valores das ponderações das alternativas. Considerando as ponderações $p_{1}, p_{2}$ e $p_{3}$ dos critérios apresentados no Quadro 3.7, o resultado da escolha de duas alternativas pode ser exemplificado na Figura 3.5.

\begin{tabular}{|c|c|c|c|c|c|c|c|}
\hline & $\begin{array}{c}\text { Critério } \\
1\end{array}$ & $\begin{array}{c}\text { Critério } \\
2\end{array}$ & $\begin{array}{c}\text { Critério } \\
3\end{array}$ & & Ponderação & & Classificação \\
\hline $\begin{array}{l}\text { Altern. } \\
1\end{array}$ & $a_{11}$ & $a_{12}$ & $a_{13}$ & $\mathrm{v}$ & $p_{1}$ & & $\begin{array}{c}\text { A 1 } 1=\left(a_{11^{\star}} p_{1}\right)_{+} \\
\left(a_{12^{\star}} p_{2}\right)+\left(a_{13^{\star}} p_{3}\right)\end{array}$ \\
\hline $\begin{array}{l}\text { Altern. } \\
\quad 2\end{array}$ & $a_{21}$ & $\mathrm{a}_{22}$ & $\mathrm{a}_{23}$ & $\lambda$ & $\begin{array}{l}\mathrm{p}_{2} \\
\mathrm{p}_{3}\end{array}$ & $=$ & $\begin{array}{c}\text { A 2 }=\left(a_{21^{\star}} p_{1}\right)_{+} \\
\left(a_{22^{*}} p_{2}\right)+\left(a_{23^{*}} p_{3}\right)\end{array}$ \\
\hline
\end{tabular}

Figura 3.5 - Obtenção da classificação final das alternativas (SOUZA, 2003).

\subsection{5 $O$ processo de tomada de decisão no contexto de reabilitação de edifícios sustentáveis}

Analisando-se o processo de tomada de decisão apresentado (item 3.1.2), verifica-se que a sua aplicação para a escolha de tecnologias construtivas para a reabilitação de edifícios depende, sobretudo, da formulação dos objetivos, definição dos critérios e formulação das alternativas de decisão.

Conforme o objetivo do presente trabalho, apresentado no capítulo 1, a sustentabilidade é uma premissa ou diretriz balizadora do processo de escolha dessas tecnologias e, portanto, está diretamente relacionada à formulação dos objetivos e definição dos critérios de decisão. 
Assim, para auxiliar a definição desses critérios, é necessário identificar os principais requisitos, especialmente os ambientais, de sustentabilidade a serem considerados no projeto de reabilitação. Esses requisitos podem ser definidos a partir das diversas metodologias de avaliação do grau de sustentabilidade do edifício, apresentadas e discutidas na sequência.

\subsection{Avaliação do grau de sustentabilidade de um edifício}

Para que os ganhos de desempenho ambiental de um edifício após sua reabilitação possam ser quantificados, é importante avaliar o seu grau de sustentabilidade, segundo uma série de critérios, muitos dos quais anteriormente abordados.

Degani (2009), a partir da síntese de diversos autores, propõe que, para serem sustentáveis, os edifícios em uso devem:

- ser viáveis economicamente: apresentar baixos custos operacionais, adequada qualidade dos materiais e sistemas, baixa ocorrência de problemas patológicos, baixa manutenção, alta eficiência energética, baixo consumo de água;

- atender demandas: responder às necessidades de seus usuários, gestores, proprietários e funcionários, por meio de avaliações pósocupação periódicas para a verificação do atendimento do edifício às demandas presentes;

- prever responsabilidade social: acolher as pessoas e a atividade fim das organizações de forma harmoniosa e igualitária;

- ter valor imobiliário: ser constituídos de materiais e componentes duráveis, ser flexíveis e adequados ao uso. Van der Voordt e Van Wegen (2005) ressaltam as seguintes características de flexibilidade: possibilidade de expansão dos espaços; disponibilidade de espaços extra; possibilidade de rearranjo dos espaços (fácil e de baixo custo); ambientes com múltiplas funções; especificação e projeto modular das vedações, coberturas, pisos, mobiliário e equipamentos; 
- produzir baixo impacto ambiental: consumir menos recursos naturais e utilizar materiais e componentes considerando a análise de seu ciclo de vida (consumo de recursos e emissões ao longo do ciclo de vida);

- ser saudáveis: edifícios sustentáveis adotam medidas para evitar patologias que possam causar danos à saúde humana. Os efeitos dos edifícios na saúde humana foram sintetizados por Van der Voordt e Van Wegen (2005) e relacionam-se à iluminação natural e iluminação artificial apropriadas, uso correto das cores, ambientes com propósitos bem definidos, caminhamentos ergonomicamente adequados, espaços verdes, qualidade do ar interior, entre outros.

Considerando-se as premissas do que seja um edifício sustentável, propostas por Degani (2010), pode-se estabelecer formas que permitam medir o grau de sustentabilidade do edifício. Para isso, pode-se adotar, por exemplo, requisitos e critérios definidos nas metodologias de certificação de sustentabilidade (LEED, CASBEE, BREEAM, entre outras).

A avaliação do grau de sustentabilidade de um edifício é tema amplamente discutido em diversos trabalhos. Particularmente no grupo de pesquisa do qual o autor participa, merecem destaque as propostas de Silva (2003); Aulicino (2008) e Degani (2009) que discutem as diversas metodologias para avaliação aplicadas nos empreendimentos de construção civil. No item 3.3, tais metodologias são abordadas para que, a partir da definição de um referencial, seja possível estabelecer os requisitos esperados para que um edifício existente, por meio da reabilitação, atinja um maior nível de sustentabilidade.

A aplicação dos princípios de sustentabilidade para a melhoria dos edifícios existentes deve partir da avaliação das características que o edifício apresenta comparando-as às exigências atuais, para que seja possível identificar as principais necessidades de reabilitação, além de mensurar os ganhos e a real redução dos impactos gerados após a intervenção.

Neste trabalho, as principais metodologias de avaliação do grau de sustentabilidade de edifícios serão utilizadas como referência para a análise 
das possíveis tecnologias a serem empregadas na reabilitação e, por isso, serão sintetizadas na sequência.

\subsection{Metodologias de avaliação de sustentabilidade de edifícios}

Uma das primeiras iniciativas relacionadas à avaliação da sustentabilidade de edifícios ocorreu com a criação do projeto Construction Related Sustainability Indicators - CRISP (1999-2001), numa cooperação entre Japão, Malásia, Canadá, Estados Unidos e a EC CRISP Network, que congrega 24 membros em 16 países europeus.

Segundo o CIB (1999), os objetivos do Projeto CRISP eram: (a) definir e validar indicadores (quantitativos e qualitativos) de sustentabilidade relacionados ao setor de construção, incluindo aspectos ambientais, econômicos, sociais, culturais e institucionais; e (b) implementar os indicadores para mensurar a sustentabilidade de edifícios e do ambiente construído e comparar a sustentabilidade de edifícios entre diferentes regiões e nações.

Depois dessa iniciativa, diferentes metodologias foram criadas em diferentes países, buscando-se a classificação do nível de sustentabilidade dos edifícios. Dentre as diferentes metodologias de avaliação de sustentabilidade de edifícios destacam-se SBTool, BREEAM, LEED, HQE, CASBEE e PH\&E. No Brasil, tais metodologias têm tido uso crescente, principalmente a $L E E D$, aplicada no país desde 2008; possui atualmente 30 edifícios certificados e 245 em processo de certificação, segundo dados do Green Building Council Brasil.

Além dessas, algumas metodologias foram desenvolvidas especificamente para o contexto brasileiro, como é o caso da AQUA, criada com base na francesa HQE; o selo PROCEL EDIFICA, que certifica edifícios quanto à sua eficiência energética; e o SELO CASA AZUL.

De acordo com o consórcio International Initiative for a Sustainable Built Environment (iiSBE), a definição do escopo de avaliação da sustentabilidade de edifícios parte da análise de três planos (LARSSON, 2010): (i) aspectos de

\footnotetext{
${ }^{2}$ Dados obtidos em junho de 2011, disponíveis em www.gbcbrasil.org.br.
} 
sustentabilidade contemplados (ii) tipos de edifícios analisados (iii) e etapas do ciclo de vida do empreendimento que abordam, os quais estão relacionados entre si como ilustra a Figura 3.6.

A partir desse modelo serão feitas as análises das diferentes metodologia, tendo-se como enfoque os edifícios habitacionais.

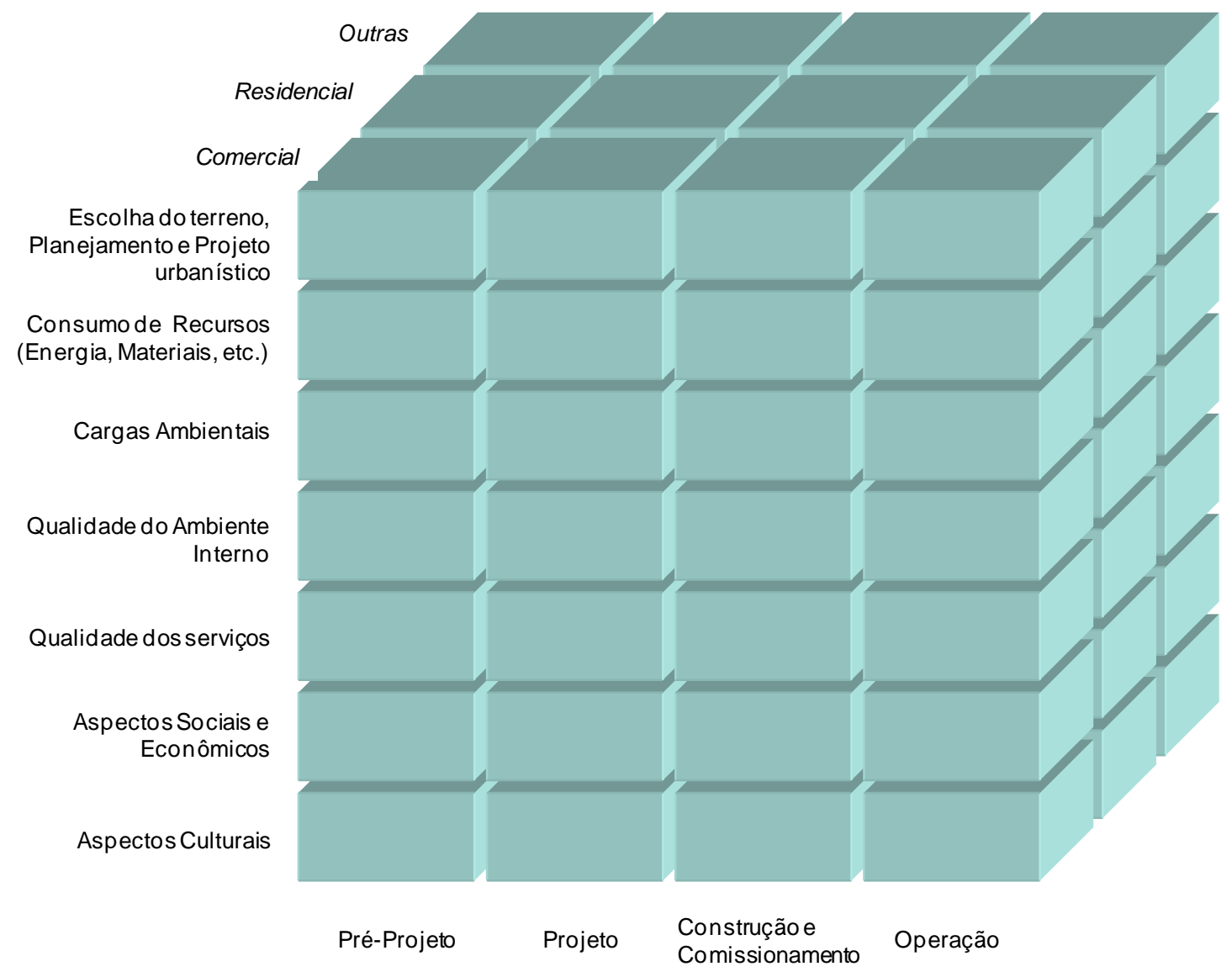

Figura 3.6 - Os três planos do escopo para a avaliação de sustentabilidade em edifícios. Fonte: Larsson (2010). (Tradução do autor)

\section{a) Metodologia SBTool}

O iiSBE, que hoje conta com 34 países participantes, foi responsável pela elaboração da metodologia SBTool que representa um esforço de colaboração internacional para desenvolver uma forma genérica de avaliação de sustentabilidade de edificações. Ela considera as diferenças regionais, incluindo as prioridades, tradições construtivas e valores culturais de cada país. 
É uma metodologia orientada à pesquisa; portanto, sem caráter comercial, diferente das demais.

Autores como Silva, (2003); Kalbusch (2006) e Degani (2009) citam essa metodologia como GBTool, que inicialmente tratava somente de aspectos ambientais e que, em 2008, passou a tratar também de aspectos sociais e econômicos. A sigla GB é relacionada a Green Building ou "edifício verde". Quando a metodologia passou a tratar também de aspectos sociais e econômicos, a sigla mudou para SB (Sustainable Building ou "edifício sustentável"). A Figura 3.7 apresenta os aspectos relacionados nesta metodologia considerados importantes para a avaliação da sustentabilidade do edifício, seja ele uma construção nova ou uma reabilitação.

\section{Definição prática dos aspectos relevantes do GB e SB}

- Consumo de combustíveis não renováveis

- Consumo de áqua

- Uso do solo

- Consumo de materiais

- Emissão de gases do efeito estufa

- Outras emissões atmosféricas

- Impactos na ecologia local

- Resíduos sólidos / efluentes líquidos

- Qualidade do ar interno, iluminacão, acústica

- Longevidade, adaptabilidade, flexibilidade

- Operacão e manutenção

- Consideracões sociais e econômicas

- Questões urbanas e de planeiamento

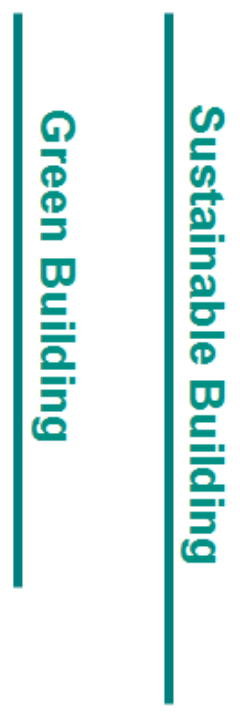

Figura 3.7 - Aspectos relevantes para a avaliação de sustentabilidade de edifícios. Fonte: Larsson (2010). (Tradução do autor)

As demais metodologias estudadas têm finalidade de avaliação para certificação; portanto, com enfoque mercadológico. 


\section{b) Metodologia BREEAM}

O BREEAM - Building Research Establishment Environmental Assessment Method, desenvolvido pelo Building Research Establishment (BRE), no Reino Unido, serviu de base para diversas outras metodologias de avaliação orientadas para o mercado (BRE, 2011). Atualmente é uma certificação comercial com valor de norma e o organismo certificador é o BRE Global. É composto por referenciais que abordam construções novas e edifícios existentes. Contempla diferentes tipos de edifícios, tais como: escritórios (BREEAM for Offices), comércio (BREEAM for Retail), escolas (BREEAM for Schools), indústrias (BREEAM Industrial), residências (BREEAM Code for sustainable homes and multi-residential), tribunais (BREEAM Courts), presídios (BREEAM Prisions). Além disto, também trata de edifícios fora do Reino Unido (BREEAM internationa).

A metodologia apresenta uma lista de verificação da qual um número mínimo de itens deve ser atendido, atribuindo a cada um deles um determinado crédito. Esses créditos são contados e ponderados de acordo com sua relevância e o resultado possibilita o enquadramento do edifício em uma das classes de desempenho ambiental propostas (aprovado, bom, muito bom, excelente) empregando-se um índice de desempenho ambiental, o EPI - Environmental Performance Index. Nessa metodologia a estrutura de avaliação é dividida em nove categorias principais: gestão, saúde e conforto, uso de energia, transporte, uso da água, uso de materiais, resíduos, uso do solo e ecologia local e poluição e inovação (BRE, 2011).

De acordo com Silva (2003), a popularidade do BREEAM deve-se a: abordagem de desempenho de referência (benchmark); cobertura abrangente de aspectos relacionados à energia, impacto ambiental, saúde e produtividade; e identificação de oportunidades realistas para a melhoria, assim como de potenciais vantagens financeiras adicionais. 


\section{c) Metodologia LEED}

Nos Estados Unidos, o United States Green Building Council (USGBC) desenvolveu o LEED - Leadership in Energy and Environmental Design. O LEED compreende os referenciais (USGBC, 2009): LEED-CS para estrutura e fachada; LEED-NC para construções novas; LEED-Cl para interiores comerciais; LEED- SCH para escolas, LEED- HC para hospitais; LEED-Homes para residências; LEED-EB para edifícios em uso; LEED-ND para desenvolvimento de bairros. Essa metodologia é baseada em especificações de desempenho ambiental e a avaliação é realizada pela atribuição de créditos para o atendimento de critérios pré-estabelecidos. O critério mínimo é o cumprimento de sete pré-requisitos focados nas áreas: locais sustentáveis, uso eficiente de água, energia e atmosfera, materiais e recursos, qualidade do ambiente interno e inovação e processo de projeto.

A certificação LEED-EB tem por objetivo a avaliação das atividades de operação e manutenção que são realizadas ao longo do uso do edifício, não tratando do processo de reabilitação. Segundo o referencial técnico da metodologia LEED-NC (USGBC, 2009), a certificação atende, além de edifícios novos, também grandes reformas. Através do documento, verifica-se que a metodologia é a mesma das construções novas, com o acréscimo de dois critérios relacionados ao requisito de materiais e recursos, que são o aproveitamento de paredes, pisos e coberturas existentes; e o aproveitamento de elementos não estruturais no interior do edifício.

\section{d) Metodologia CASBEE}

A metodologia japonesa, a CASBEE - Comprehensive Assessment System for Building Environmental Efficiency, é um referencial que é aplicado a diversos tipos de edifícios: de escritórios, escolares, comerciais, restaurantes, espaços comunitários, hospitais, hotéis, residenciais (exceto unifamiliares) (IBEC, 2008). É utilizado em cada uma das etapas de um dado empreendimento: planejamento (programa e escolha do local); construções novas (concepção e execução); edifícios existentes e reabilitação. O CASBEE utiliza o conceito de Eficiência Ambiental do Edifício (BEE - a sigla vem da expressão em inglês: 
Building Environmental Efficiency), que é o resultado da relação entre a qualidade e o desempenho ambiental do edifício (melhoria da qualidade de vida dos usuários) e as cargas ambientais geradas por tal edifício no ambiente externo.

As categorias referentes a desempenho e qualidade são:

- ambiente interno - ruído e acústica, conforto térmico, iluminação, qualidade do ar;

- qualidade dos serviços - funcionalidade, durabilidade e confiabilidade, flexibilidade e adaptabilidade;

- ambiente externo - manutenção e criação de ecossistemas, paisagismo, características locais e cultura.

As categorias referentes à redução de cargas ambientais são:

- energia - carga térmica, utilização de energia natural, eficiência dos sistemas prediais, operação eficiente;

- recursos materiais - água, uso de materiais de baixa carga ambiental;

- ambiente externo ao terreno - poluição do ar, ruídos e odores, acesso à ventilação, acesso à iluminação, efeito ilha de calor, carga na infraestrutura local.

A estrutura de avaliação e a apresentação de resultado da CASBEE derivam do SBTool, sendo que cada item avaliado recebe uma pontuação em termos de qualidade, desempenho e redução das cargas ambientais. Em seguida, ocorre a ponderação dentro da categoria correspondente (SILVA, 2003).

\section{e) Metodologia $H Q E$}

Na França, em 1996, a Association HQE foi criada como uma iniciativa em prol da elevada qualidade ambiental das edificações francesas (CERTIVÉA, 2008). A Associação estabeleceu 14 grandes preocupações ambientais a serem solucionadas em um movimento denominado Démarche HQE - Haute Qualité 
Environnementale du Bâtiment que contém as metas a serem alcançadas pelo empreendimento em questões ambientais, sanitárias e de conforto. Em 2005, a primeira versão definitiva do referencial para edifícios de escritórios e escolas já saiu como norma francesa NF Bâtiments Tertiaires - Démarche HQE.

Os referenciais para a certificação de edifícios na França (HQE) estão disponíveis para os seguintes tipos de edifícios: escritório e escolas; hotéis; hospitais; centros de distribuição; comércio; indústrias; esportivos; rodovias; desenvolvimento de bairros; edifícios existentes; residências multifamiliares e residências unifamiliares.

As preocupações ambientais consideradas são: relação do edifício com seu entorno; escolha integrada dos produtos, sistemas e processos construtivos; canteiro de obra com baixo impacto ambiental; gestão da energia, gestão da água, gestão dos resíduos, gestão da manutenção, conforto higrotérmico, conforto acústico, conforto visual e conforto olfativo, qualidade sanitária dos ambientes, qualidade do ar e da água.

\section{f) Metodologia AQUA}

Em abril de 2008, a Fundação Carlos Alberto Vanzolini (FCAV, 2010) lançou a metodologia AQUA, o primeiro referencial brasileiro para avaliação e certificação do desempenho ambiental de edifícios. Inicialmente, este referencial aplicava-se a edificações comerciais e escolares, sendo que, posteriormente, passou a contemplar também hotéis e edifícios habitacionais e partiu de uma parceria com o Certivéa, organismo detentor do referencial e dos processos de certificação da metodologia francesa Démarche HQE.

Assim, o processo AQUA é uma versão brasileira do HQE, e também trata dos 14 itens citados no referencial da metodologia francesa, adaptada de acordo com as normas brasileiras de conforto e desempenho. Para obter a certificação, o empreendedor da construção deve estabelecer o controle total do empreendimento em todas as suas fases: programa; concepção (projeto); realização (obra) e operação (uso), por meio do Sistema de Gestão do 
Empreendimento (SGE), para que sejam atendidos os critérios de desempenho da Qualidade Ambiental do Edifício (QAE).

\section{g) Metodologia PROCEL EDIFICA}

Outra iniciativa brasileira de avaliação de edifícios é o PROCEL EDIFICA, incremento do Programa Nacional de Conservação de Energia Elétrica. Esta iniciativa partiu devido à Lei 10.295/2001, conhecida como Lei da Eficiência Energética, principal marco regulatório da matéria no país. Esta Lei, que dispõe sobre a política nacional de conservação e uso racional de energia, determina a necessidade de desenvolvimento de mecanismos que promovam a eficiência energética no país. O decreto que regulamenta esta lei, estabeleceu que fossem desenvolvidos mecanismos para determinar os níveis mínimos de eficiência energética em edifícios (BRASIL, 2001).

O Ministério de Minas e Energia, a Eletrobrás, por meio do PROCEL EDIFICA, em parceria com o INMETRO (Instituto Nacional de Metrologia, Normalização e Qualidade Industrial), no âmbito do Programa Brasileiro de Etiquetagem, PBE, promoveram a elaboração do Regulamento Técnico da Qualidade, para a etiquetagem de edifícios comerciais, de serviços e públicos, especialmente voltada à Eficiência Energética das Edificações, aliada ao Conforto Ambiental. Este documento, publicado em julho de 2009, inclui três requisitos principais: 0 desempenho térmico da envoltória; a eficiência e potência instalada do sistema de iluminação; e eficiência do sistema de condicionamento do ar. A classificação do nível de eficiência energética do edifício é definida conforme o cumprimento de determinados requisitos, variando do nível A ao E (BRASIL, 2010).

Com relação ao desempenho térmico da envoltória, no cálculo da eficiência energética, deve-se considerar: transmitância térmica; cores e absortância de superfícies; cálculo do Fator Forma ${ }^{3}$ e Fator Altura ${ }^{4}$; percentual de abertura da fachada; e ângulos de sombreamento. Com esses dados, através de uma

\footnotetext{
${ }^{3}$ Fator Forma (FF): Área da envoltória / Volume total da edificação.

${ }^{4}$ Fator Altura (FA): Área de projeção da cobertura / Área total construída.
} 
equação, calcula-se o indicador de consumo da envoltória ( $\left(\mathrm{I}_{\text {env }}\right)$, os limites máximo e mínimo deste indicador para a mesma volumetria, e compara-se o $I_{\text {env }}$ com os limites para se identificar o nível de eficiência energética da envoltória.

Para a classificação do sistema de iluminação, considera-se: divisão dos circuitos; contribuição da luz natural; e desligamento automático do sistema de iluminação. A avaliação do sistema de iluminação deve ser realizada através do método da área do edifício, ou do método das atividades do edifício. $O$ método da área do edifício avalia de forma conjunta todos os ambientes do edifício e atribui um único valor limite para a avaliação do sistema de iluminação. Este método deve ser utilizado para edifícios com ate três atividades principais, ou para atividades que ocupem mais de $30 \%$ da área do edifício. O método das atividades do edifício avalia separadamente os ambientes do edifício e deve ser utilizado para edifícios em que o método anterior não e aplicável.

Quanto ao sistema de ar condicionado, os pré-requisitos são avaliados em cada ambiente separadamente. Para classificação do nível de eficiência, é obrigatório que os edifícios condicionados artificialmente possuam sistemas de condicionamento de ar com eficiência conhecida.

\section{h) Metodologia CASA AZUL}

Além da metodologia AQUA e do selo PROCEL EDIFICA, existe também o selo Casa Azul desenvolvido pela CAIXA, que se aplica a todos os empreendimentos habitacionais propostos para financiamento. A CAIXA é responsável por grande parte do financiamento habitacional do país, sendo responsável por $71 \%$ de todo o crédito imobiliário concedido no ano de 2009 (CAIXA, 2010). Destaca-se, nesse montante, a prioridade dada à habitação de interesse social, que é o principal alvo para a concessão do selo.

O método utilizado para a concessão do selo Casa Azul consiste em verificar, durante a análise de viabilidade técnica do empreendimento, o atendimento aos critérios estabelecidos. São 53 critérios de avaliação, distribuídos em seis 
categorias: qualidade urbana; projeto e conforto; eficiência energética; conservação de recursos materiais; gestão da água e práticas sociais. A certificação se divide em três níveis: o "nível bronze" é concedido para o atendimento de 19 critérios pré-definidos. Esses critérios obrigatórios, somados a 6 critérios quaisquer dos demais conferem o "nível prata", e, da mesma forma, somados a 12 dos demais critérios, conferem o "nível ouro".

Apesar desta metodologia se aplicar a qualquer empreendimento habitacional, o "nível bronze" do selo é concedido somente aos empreendimentos cujo valor de avaliação da unidade habitacional não ultrapasse determinado limite que, em dezembro/2011, em cidades como São Paulo e Rio de Janeiro correspondia a $R \$ 130.000,00$ (centro e trinta mil reais), segundo o documento do ano de 2010 (CAIXA, 2010).

\section{i) Metodologia PH\&E - Patrimoine Habitat \& Environment}

Esta metodologia, desenvolvida na França, é aplicada para a avaliação da sustentabilidade de projetos de reabilitação de edifícios. De acordo com o referencial técnico desta metodologia (CERQUAL, 2009), a mesma se aplica a edifícios de mais de 10 anos, nos quais são estabelecidos níveis mínimos de desempenho a serem alcançados para temas relacionados à tecnologia, conforto e meio ambiente.

Essa metodologia difere das demais porque seu objetivo é medir as melhorias alcançadas após a realização das intervenções. Assim, antes da sua aplicação, deve ser realizado um diagnóstico do edifício, de forma a se obter informações sobre seu estado e desempenho, antes do processo de reabilitação.

A metodologia considera 4 grupos principais de requisitos: a organização e informação técnica e ambiental sobre o projeto, a qualidade da envoltória (fachadas, cobertura) e as áreas comuns, a proteção contra fogo e condições de saúde dos ocupantes, e o conforto e desempenho dos ambientes (Figura 3.8). Esses grupos são subdividids em 11 itens, em que são estabelecidos, no total, 21 requisitos para a avaliação do grau de sustentabilidade da reabilitação. 


\begin{tabular}{|c|c|c|c|}
\hline $\begin{array}{l}\text { Organização e } \\
\text { Informação }\end{array}$ & $\begin{array}{l}\text { Saúde e Segurança } \\
\text { contra incêndio }\end{array}$ & $\begin{array}{c}\text { Qualidade da envoltória } \\
\text { e Áreas comuns }\end{array}$ & $\begin{array}{c}\text { Conforto e } \\
\text { Desempenho }\end{array}$ \\
\hline $\begin{array}{c}\text { Organização e } \\
\text { Gestão de projetos }\end{array}$ & $\begin{array}{l}\text { Segurança contra } \\
\text { incêndio }\end{array}$ & $\begin{array}{l}\text { Qualidade da } \\
\text { fachada e cobertura }\end{array}$ & $\begin{array}{l}\text { Tecnologias } \\
\text { utilizadas }\end{array}$ \\
\hline Canteiro verde & $\begin{array}{l}\text { Qualidade sanitária } \\
\text { das residências }\end{array}$ & $\begin{array}{l}\text { Componentes das } \\
\text { áreas comuns }\end{array}$ & $\begin{array}{l}\text { Desempenho } \\
\text { energético }\end{array}$ \\
\hline $\begin{array}{c}\text { Atitudes e açốes } \\
\text { verdes }\end{array}$ & $\begin{array}{l}\text { Acessibilidade do } \\
\text { edifício }\end{array}$ & - & Conforto acústico \\
\hline
\end{tabular}

Figura 3.8 - Requisitos da metodologia PH\&E (Tradução do autor).

O grupo de requisitos relacionados à organização e informação inclui os temas: organização e gestão de projetos, que considera a integração de princípios de gestão ambiental, controle dos processos durante a fase de projeto e organização para atingir o desempenho requerido, de acordo com o potencial de melhoria definido através do diagnóstico; canteiro verde, que avalia a organização da obra, a gestão de resíduos da construção e o controle dos impactos do canteiro de obras; e atitudes e ações verdes, que consideram a informação sobre as atitudes dos usuários durante o uso e operação do edifício.

O grupo de saúde e segurança contra incêndio considera a qualidade sanitária das residências, de acordo com critérios que permitam a melhoria da qualidade do ar interno e da água, e a acessibilidade do edifício, além da segurança contra incêndio.

O terceiro grupo, qualidade da envoltória e as áreas comuns, está relacionado à análise da qualidade e estado de conservação dos elementos de fachada e cobertura, além de componentes da área comum, como equipamentos coletivos e a existência de locais para a segregação de resíduos.

Por fim, o grupo de requisitos relacionado ao conforto e desempenho dos ambientes trata das tecnologias utilizadas, como instalações elétricas, sanitárias e sistemas de ventilação e climatização, do conforto acústico relacionado a ruídos externos e internos, e ainda, do desempenho energético comparado ao consumo anterior à reabilitação. 
Das diversas metodologias descritas, verifica-se que os requisitos considerados diferem de acordo com as características e os objetivos de cada uma. Na metodologia CASBEE, por exemplo, os requisitos se referem a diferentes aspectos ambientais, enquanto o PROCEL EDIFICA abrange apenas os relacionados à eficiência energética.

O Quadro 3.8 resume os principais requisitos identificados em cada uma das metodologias apresentadas.

\begin{tabular}{|c|c|}
\hline Metodologias & Requisitos \\
\hline LEED-NC & $\begin{array}{l}\text { - } \quad \text { Locais sustentáveis } \\
\text { - } \quad \text { Eno eficiente de água } \\
\text { - } \quad \text { Materiais e recursora } \\
\text { - } \text { Qualidade do ambiente interno } \\
\text { - Inovação e processo de projeto }\end{array}$ \\
\hline SBTool & 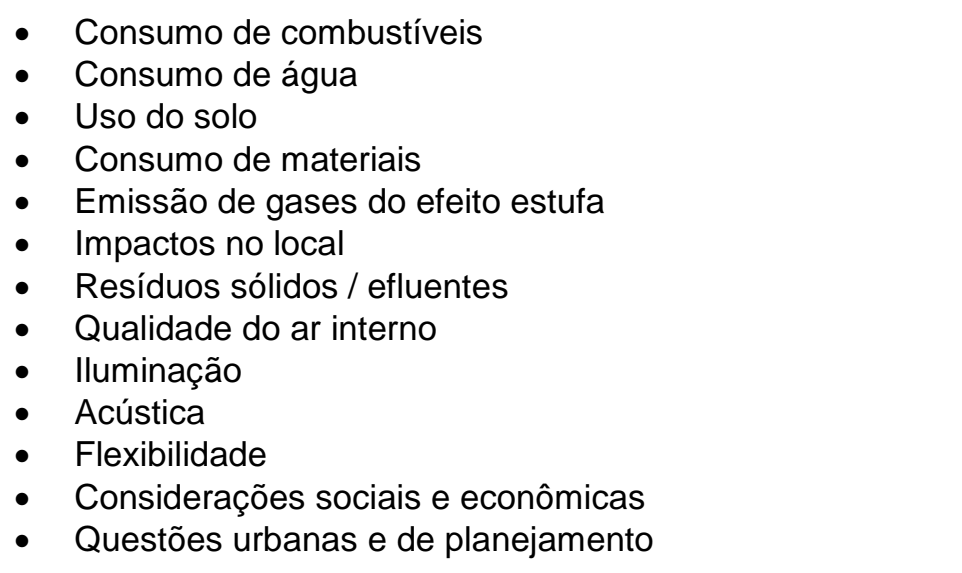 \\
\hline BREEM & $\begin{array}{l}\text { - Gestão } \\
\text { - Saúde e conforto } \\
\text { - Uso de energia } \\
\text { - } \quad \text { Uransporte } \\
\text { - Uso da água } \\
\text { - Uso de materiais } \\
\text { - } \text { Usíduos } \\
\text { - Ecologia local } \\
\text { - Poluição } \\
\text { - Inovação }\end{array}$ \\
\hline CASBEE & $\begin{array}{l}\text { - Ambiente interno (conforto acústico, conforto térmico, } \\
\text { iluminação, qualidade do ar) } \\
\text { - Qualidade dos serviços (funcionalidade, durabilidade e }\end{array}$ \\
\hline
\end{tabular}




\begin{tabular}{|c|c|}
\hline CASBEE & $\begin{array}{l}\text { Confiabilidade, flexibilidade e adaptabilidade) } \\
\text { - } \\
\text { - Embiente externo } \\
\text { eficiência dos sistemas prediais, operação eficiente) } \\
\text { - Recursos materiais (água, uso de materiais de baixa } \\
\text { carga ambiental) } \\
\text { - Ambiente externo ao terreno (poluição do ar, ruídos e } \\
\text { odores, acesso à ventilação, acesso à iluminação, etc.) }\end{array}$ \\
\hline CASA AZUL & $\begin{array}{l}\text { - Qualidade urbana } \\
\text { - } \text { Projeto e conforto } \\
\text { - } \text { Eficiência energética } \\
\text { - Gestão da água } \\
\text { - Práticas sociais }\end{array}$ \\
\hline HQE e AQUA & $\begin{array}{l}\text { - } \text { Relação do edifício com seu entorno } \\
\text { - } \text { Escolha integrada de produtos e processos construtivos } \\
\text { - Gestão da obra com baixo impacto ambiental } \\
\text { - Gestão da água } \\
\text { - Gestão dos resíduos } \\
\text { - } \quad \text { Gestão da manutenção } \\
\text { - Qualidade sanitária dos ambientes } \\
\text { - Qualidade do ar }\end{array}$ \\
\hline PROCEL EDIFICA & $\begin{array}{l}\text { - Desempenho térmico da envoltória } \\
\text { - Classificação do sistema de iluminação } \\
\text { - Eficiência do sistema de condicionamento do ar }\end{array}$ \\
\hline PH\&E & 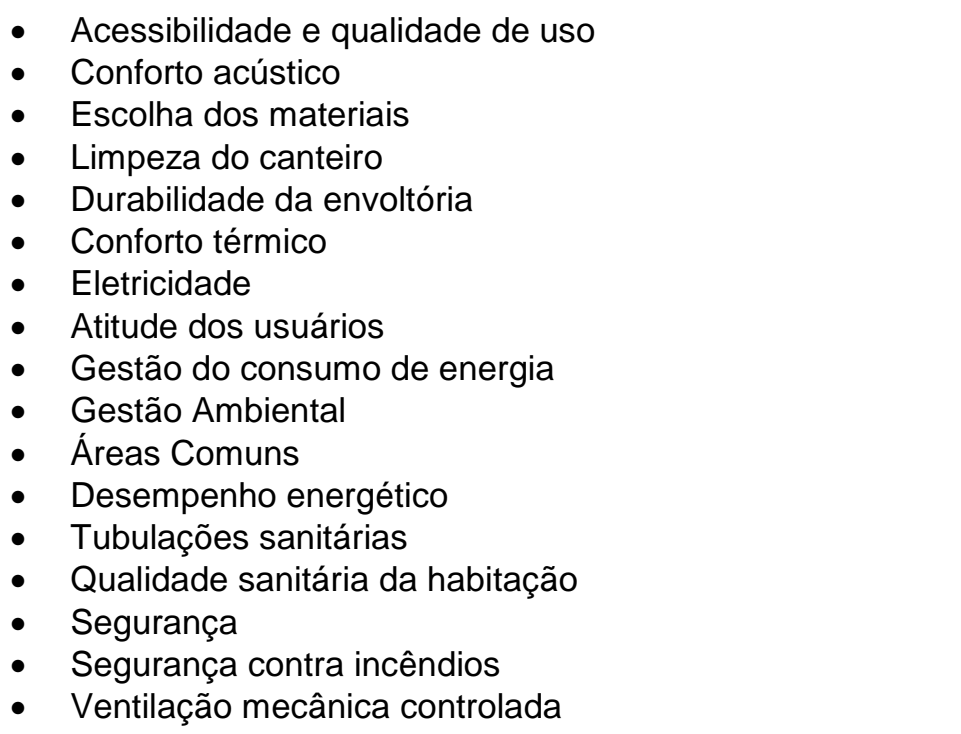 \\
\hline
\end{tabular}

Quadro 3.8 - Resumo dos requisitos relacionados às metodologias de avaliação de edifícios. 
Os requisitos estabelecidos em cada metodologia de avaliação serão analisados na sequência, objetivando definir um conjunto que possa ser aplicado em um processo de escolha de tecnologias para reabilitação.

\subsection{Identificação dos requisitos de sustentabilidade relevantes na reabilitação}

As metodologias de avaliação da sustentabilidade de edifícios, anteriormente apresentadas, têm como característica comum o estabelecimento de requisitos e critérios para avaliar o grau de sustentabilidade do edifício, ainda que sejam diferentes de uma metodologia para outra. Alguns são mais genéricos, como o que prevê o aumento da eficiência energética do edifício, outros mais específicos, como o controle da carga térmica.

Analisando-se o Quadro 3.8 pode-se verificar que os mesmos requisitos estão presentes nas diferentes metodologias, mesmo que de maneira ligeiramente diferente, como por exemplo: uso eficiente da água ( $L E E D)$; consumo de água (SBToo); uso da água (BREEAM); recursos materiais - água (CASBEE); gestão da água $(A Q U A)$; todos se referindo ao uso eficiente da água. Desta forma, no Quadro 3.9 foram identificados e relacionados os requisitos comuns às metodologias.

Verifica-se pelo Quadro 3.9, que a maioria das metodologias trata, sobretudo, dos aspectos ambientais da sustentabilidade, Contudo, identifica-se também que alguns dos requisitos apresentados nas metodologias estão relacionados à sustentabilidade social e econômica, como é o caso do conforto térmico (CASBEE, HQE, PH\&E), que considera a qualidade do ambiente ao usuário, ou a eficiência energética (PROCEL EDIFICA, BREEAM), que permite a redução de custos de operação do edifício.

Além dos requisitos destacados nas metodologias analisadas, ao se pensar na reabilitação de edifícios, outro aspecto relevante para a sustentabilidade é a interface das tecnologias a serem empregadas com o edifício existente, pois o uso de métodos construtivos que causam menor impacto no edifício existente, 
ou que privilegiam a energia incorporada, podem contribuir para a redução dos custos econômicos, sociais e ambientais da reabilitação.

Uma análise cuidadosa do Quadro 3.9 permite considerar que os principais requisitos que contribuem para que o edifício reabilitado seja ambientalmente mais sustentável são:

- Otimização do uso da água;

- Otimização do desempenho energético;

- Conforto térmico;

- Conforto acústico;

- Conforto visual;

- Gestão de resíduos;

- Relação com o entorno;

- Compatibilidade com a construção existente. 


\begin{tabular}{|c|c|c|c|c|c|c|c|}
\hline Comparativo & LEED-NC & SBTool & BREEM & CASBEE & HQE e AQUA & PROCEL EDIFICA & PH\&E \\
\hline $\begin{array}{l}\text { Otimização do } \\
\text { desempenho } \\
\text { energético }\end{array}$ & Energia e atmosfera & & Uso de energia & $\begin{array}{l}\text { Energia (carga térmica, utilização } \\
\text { de energia natural, eficiência dos } \\
\text { sistemas prediais, operação } \\
\text { eficiente) }\end{array}$ & Gestão da energia & $\begin{array}{l}\text { Desempenho térmico da } \\
\text { envoltória } \\
\text { Classificação do sistema } \\
\text { de iluminação } \\
\text { Eficiência do sistema de } \\
\text { condicionamento do ar }\end{array}$ & \begin{tabular}{|l} 
Eletricidade \\
Gestão do consumo de energia \\
Desempenho energético
\end{tabular} \\
\hline $\begin{array}{l}\text { Relação com } \\
\text { o entorno }\end{array}$ & Locais sustentáveis & $\begin{array}{l}\text { Impactos no local } \\
\text { Questões urbanas e de } \\
\text { planejamento }\end{array}$ & Ecologia local & $\begin{array}{l}\text { Ambiente externo ao terreno } \\
\text { (poluição do ar, ruídos e odores, } \\
\text { acesso à ventilação, acesso à } \\
\text { iluminação, efeito ilha de calor, } \\
\text { carga na infraestrutura local) } \\
\end{array}$ & Relacão do edifício com & & Áreas Comuns \\
\hline $\begin{array}{l}\text { Uso eficiente } \\
\text { da água }\end{array}$ & Uso eficiente de água & Consumo de água & Uso da água & $\begin{array}{l}\text { Recursos materiais (água, uso de } \\
\text { materiais de baixa carga } \\
\text { ambiental) }\end{array}$ & $\begin{array}{l}\text { Gestão da água, } \\
\text { Qualidade da água }\end{array}$ & & Tubulações sanitárias \\
\hline $\begin{array}{l}\text { Gestão de } \\
\text { resíduos }\end{array}$ & Materiais e recursos & $\begin{array}{l}\text { Consumo de materiais } \\
\text { Resíduos sólidos / } \\
\text { efluentes }\end{array}$ & $\begin{array}{l}\text { Uso de } \\
\text { materiais }\end{array}$ & & Gestão dos resíduos & & $\begin{array}{l}\text { Limpeza do canteiro } \\
\text { Resíduos domésticos }\end{array}$ \\
\hline $\begin{array}{l}\text { Conforto } \\
\text { térmico }\end{array}$ & $\begin{array}{l}\text { Qualidade do } \\
\text { ambiente interno }\end{array}$ & & $\begin{array}{l}\text { Saúde e } \\
\text { conforto }\end{array}$ & $\begin{array}{l}\text { Ambiente interno (conforto } \\
\text { acústico, conforto térmico, } \\
\text { iluminação, qualidade do ar) }\end{array}$ & \begin{tabular}{|l|}
$\begin{array}{l}\text { Conforto higrotérmico, } \\
\text { conforto acústico, conforto } \\
\text { visual e conforto olfativo }\end{array}$ \\
\end{tabular} & & \begin{tabular}{|l} 
Conforto térmico \\
Ventilação mecânica controlada
\end{tabular} \\
\hline $\begin{array}{l}\text { Qualidade do } \\
\text { ar }\end{array}$ & $\begin{array}{l}\text { Qualidade do } \\
\text { ambiente interno }\end{array}$ & Qualidade do ar interno & $\begin{array}{l}\text { Saúde e } \\
\text { conforto }\end{array}$ & $\begin{array}{l}\text { Ambiente interno (conforto } \\
\text { acústico, conforto térmico, } \\
\text { iluminação, qualidade do ar) }\end{array}$ & $\begin{array}{l}\text { Qualidade sanitária dos } \\
\text { ambientes } \\
\text { Qualidade do ar }\end{array}$ & & Qualidade sanitária da habitação \\
\hline $\begin{array}{l}\text { Emissão de } \\
\text { gases do } \\
\text { efeito estufa }\end{array}$ & & $\begin{array}{l}\text { Emissão de gases do } \\
\text { efeito estufa }\end{array}$ & Poluição & & & & \\
\hline $\begin{array}{l}\text { Conforto } \\
\text { visual }\end{array}$ & $\begin{array}{l}\text { Qualidade do } \\
\text { ambiente interno }\end{array}$ & |luminação & $\begin{array}{l}\text { Saúde e } \\
\text { conforto }\end{array}$ & $\begin{array}{l}\text { Ambiente interno (conforto } \\
\text { acústico, conforto térmico, } \\
\text { iluminação, qualidade do ar) }\end{array}$ & \begin{tabular}{|l|} 
Conforto higrotérmico, \\
conforto acústico, conforto \\
visual e conforto olfativo
\end{tabular} & & \\
\hline $\begin{array}{l}\text { Conforto } \\
\text { acústico }\end{array}$ & $\begin{array}{l}\text { Qualidade do } \\
\text { ambiente interno }\end{array}$ & Acústica & $\begin{array}{l}\text { Saúde e } \\
\text { conforto }\end{array}$ & $\begin{array}{l}\text { Ambiente interno (conforto } \\
\text { acústico, conforto térmico, } \\
\text { iluminação, qualidade do ar) }\end{array}$ & \begin{tabular}{|l|} 
Conforto higrotérmico, \\
conforto acústico, conforto \\
visual e conforto olfativo
\end{tabular} & & Conforto acústico \\
\hline & $\begin{array}{l}\text { Inovação e processo } \\
\text { de projeto }\end{array}$ & $\begin{array}{l}\text { Consumo de } \\
\text { combustíveis }\end{array}$ & Gestão & $\begin{array}{l}\text { Qualidade dos serviços } \\
\text { (funcionalidade, durabilidade e } \\
\text { confiabilidade, flexibilidade e }\end{array}$ & \begin{tabular}{|l|} 
Escolha integrada dos \\
produtos, sistemas e \\
processos construtivos
\end{tabular} & & $\begin{array}{l}\text { Acessibilidade e qualidade de uso } \\
\text { Elevadores } \\
\text { Escolha dos materiais }\end{array}$ \\
\hline Outros & & $\begin{array}{l}\text { Flexibilidade } \\
\text { Considerações sociais e } \\
\text { econômicas }\end{array}$ & Uso do solo & $\begin{array}{l}\text { adaptabilidade) } \\
\text { Ambiente externo }\end{array}$ & $\begin{array}{l}\text { Canteiro de obra com baixo } \\
\text { impacto ambiental } \\
\text { Gestão da manutenção }\end{array}$ & & \begin{tabular}{|l} 
Durabilidade da envoltória \\
Tecnologias \\
Geometria do guarda corpo \\
Atitude dos usuários \\
Segurança \\
Segurança contra incêndios
\end{tabular} \\
\hline
\end{tabular}

Quadro 3.9 - Comparativo entre requisitos propostos pelas metodologias de avaliação de sustentabilidade. 
São definidas, a seguir, as estratégias potenciais para determinar a forma com que estes requisitos podem ser utilizados na escolha de tecnologias construtivas para a reabilitação.

Como destacado anteriormente, a sustentabilidade deve contemplar os aspectos ambiental, social e econômico. Porém, as metodologias apresentadas abordam principalmente o aspecto ambiental da sustentabilidade, sendo que os aspectos social e econômico ficam menos explícitos nas metodologias, sendo, muitas vezes, decorrentes da ação ambiental. São exemplos de requisitos sociais a relação com o entorno, saúde e conforto, qualidade do ambiente, que são mencionados em algumas das metodologias. Com relação ao aspecto econômico, através do atendimento de requisitos como a otimização do uso da água ou do desempenho energético, pode-se alcançar a viabilidade econômica do empreendimento.

\subsubsection{Otimização do uso da água}

Em todas as metodologias analisadas, exceto na PROCEL EDIFICA, que trata especificamente de eficiência energética, a otimização do uso da água é considerado um requisito importante na definição do grau de sustentabilidade do edifício.

A redução do consumo de água potável e a gestão de águas pluviais e servidas são as principais estratégias para garantir o uso eficiente desse recurso. A redução do consumo deve ser tratada tanto com relação à redução da demanda, empregando-se sistemas economizadores, equipamentos de alta eficiência e a instalação de medição individualizada; quanto com relação à otimização da oferta, que pode ser obtida pela reutilização da água para usos não potáveis. Além disso, a captação de água da chuva pode ser uma estratégia para economizar água em atividades como irrigação de plantas ou lavagem em geral.

\subsubsection{Otimização do desempenho energético}

Assim como o uso eficiente da água, a importância do desempenho energético na sustentabilidade de um edifício é evidenciada nas diferentes metodologias 
de avaliação. Conforme definido na metodologia AQUA, o desempenho energético de um edifício está relacionado à concepção arquitetônica, à redução do consumo de energia elétrica e ao uso de energias renováveis (FCAV, 2010). De acordo com a metodologia, a arquitetura influi na eficiência energética pela melhoria do desempenho da envoltória para limitar desperdícios de energia. Para isso, devem ser analisados fatores como a transmitância térmica de elementos da envoltória, sombreamentos, aberturas envidraçadas, entre outros.

A estratégia para a redução do consumo de energia elétrica está relacionada à utilização de equipamentos de alta eficiência energética, além do controle do consumo, com condições de conforto compatíveis ao uso. Além disto, deve-se priorizar o uso de energias renováveis de acordo com a disponibilidade da região (FCAV, 2010).

A implantação de tecnologias para a geração de energia renovável é um importante fator a ser considerado na avaliação do grau de sustentabilidade de uma reabilitação. A geração de energia dentro do próprio edifício pode ser realizada através de tecnologias que aproveitam a área da envoltória do edifício, como é o caso de elementos de captação da energia solar usados para geração de energia elétrica ou para aquecimento de água.

\subsubsection{Conforto térmico}

Das metodologias analisadas a $L E E D$, a BREEAM, a CASBEE, a $H Q E$ e a $A Q U A$ consideram o desempenho térmico de edificações como um requisito relevante para o grau de sustentabilidade. Para proporcionar conforto térmico em uma edificação, é importante a definição de estratégias que combinem a irradiação solar, a ventilação natural e a climatização artificial.

Com relação à irradiação solar, é importante assegurar o controle ao longo das estações do ano, garantindo a sua redução no verão e seu aumento no inverno. Dentre as técnicas de controle de irradiação solar estão as proteções solares adaptadas a cada orientação e estação do ano, a otimização da área 
de aberturas envidraçadas, e a substituição de superfícies construídas por superfícies com vegetação, como é o caso de coberturas verdes.

A ventilação também deve ser adaptável às diferentes épocas do ano, de forma que em épocas de clima frio a velocidade do ar deve ser controlada para que não prejudique o conforto. Assim, os fatores que influenciam na ventilação são principalmente a área de abertura e o seu posicionamento para que se permita a ventilação cruzada. Assim, a decisão do tipo de esquadria de janela, de acordo com as características do edifício e suas condições de uso, é fundamental para proporcionar níveis de conforto térmico adequados ao uso.

\subsubsection{Conforto acústico}

Em praticamente todas as metodologias analisadas, o conforto dos usuários é considerado como requisito para a sustentabilidade dos edifícios, em algumas delas - SBTool, a CASBEE, a HQE e a AQUA - conforto acústico aparece explicitamente como requisito, prevendo-se a otimização da posição e da área dos ambientes, de forma que ambientes ruidosos não fiquem contíguos aos silenciosos. Em edifícios a serem reabilitados esta otimização pode ser limitada, devido ao possível aproveitamento da estrutura e paredes existentes e também em função da sua localização. Na reabilitação, as vedações - internas ou externas - serão, então, responsáveis por garantir os níveis de conforto acústico requeridos, devendo ser projetadas com características que thes permitam adequado desempenho. .

\subsubsection{Conforto visual}

O conforto visual está relacionado à garantia da iluminação adequada, além do acesso a vistas externas. É considerado como requisito em cinco das sete metodologias analisadas. As estratégias para proporcionar a iluminação adequada de forma sustentável devem considerar um máximo aproveitamento da iluminação natural, além da possibilidade de controle da iluminação artificial. Este controle está relacionado com as aberturas envidraçadas, que devem ser definidas para cada ambiente, com cuidado para evitar o ofuscamento em ambientes sensíveis a este aspecto. 
Com relação à iluminação artificial, é importante a utilização de técnicas para a sua otimização, como o correto dimensionamento da quantidade de luminárias, sistemas de controle de presença, sensores fotoelétricos e iluminação direcionada.

\subsubsection{Gestão de resíduos}

As estratégias para minimizar a geração de resíduos no processo de reabilitação devem visar à redução, ao reuso e à reciclagem dos materiais no canteiro de obras.

A metodologia BREEAM (BRE, 2011) considera os seguintes critérios na gestão de resíduos: volume $\left(\mathrm{m}^{3}\right)$ de resíduos gerados; porcentagem de resíduos não perigosos em relação aos perigosos gerados; volume de utilização de materiais reciclados ou reutilizados na obra; e gestão de resíduos na fase de operação do edifício (espaço dedicado à segregação e armazenagem de resíduos recicláveis, estatísticas de geração de resíduos na operação).

A redução da geração de resíduos está relacionada a dois fatores: a racionalização do processo de reabilitação e ao aproveitamento dos subsistemas existentes. Para tanto, o Projeto deve prever o máximo aproveitamento dos elementos existentes da construção, de forma a reduzir as necessidade de demolição e consequente geração de resíduos.

Com relação aos resíduos gerados, deve-se priorizar seu reaproveitamento ou reciclagem dos não perigosos. Além disto, deve ser implementado um plano de gestão de resíduos, tanto durante a reabilitação quanto na operação, que identifique os materiais a serem reciclados, prevendo a segregação de materiais recicláveis pela coleta seletiva.

\subsubsection{Relação com o entorno}

Cuidados com o impacto no entorno devem estar presentes durante toda a atividade de reabilitação. Este critério está relacionado, principalmente, aos 
incômodos sonoros, à poluição e a incômodos relacionados ao transporte local, como interdição de ruas.

O controle de incômodos sonoros deve ser previsto planejando-se as atividades ruidosas e a escolha de métodos construtivos com baixa emissão de ruídos. Os processos construtivos devem evitar, ainda, a emissão de poluição devida à queima de produtos, emissão de material particulado e a contaminação do solo ou de mananciais na proximidade.

Além disso, segundo o REABILITA (2007), deve ser prevista uma logística de transporte para recebimento de materiais, de forma a prever problemas relacionados ao acesso de caminhões à obra ou ainda necessidades de interdições de ruas, como ocorre nas obras realizadas em regiões adensadas. Ainda, deve-se garantir a limpeza das ruas do entorno, através da utilização de dispositivos de contenção e lava-rodas para estes caminhões.

\subsubsection{Compatibilidade com a construção existente}

Na fase de execução da reabilitação, as soluções tecnológicas, segundo Aguiar et al.(2005), devem proporcionar boas condições de construtibilidade e garantir o desempenho do edifício em uso. Isto significa que as tecnologias empregadas devem ser adequadas às características da construção e dos materiais pré-existentes (sobretudo quanto às suas características físicas, químicas e mecânicas), procurando assegurar a completa compatibilidade. Segundo os autores, o uso de novas tecnologias é necessário e até mesmo imprescindível em determinadas ações de conservação; no entanto, é preciso garantir as condições de compatibilidade do edifício como um todo.

\subsection{Considerações finais}

A tomada de decisão para a reabilitação de edifícios foi tratada neste capítulo tendo-se como base os conceitos de sustentabilidade que, de acordo com a revisão bibliográfica realizada, têm como principais objetivos: a redução do consumo de recursos; a redução de emissão de gases do efeito estufa; a redução de geração de resíduos; e o conforto dos usuários. 
Assim, buscando-se definir os requisitos relevantes para a escolha de tecnologias construtivas a serem utilizadas na reabilitação de um edifício, foram analisadas as diversas metodologias de avaliação de sustentabilidade, que estabelecem requisitos práticos para avaliar se um edifício é ou não sustentável. A partir dos requisitos propostos nessas metodologias foram identificados os relevantes à escolha de tecnologias para a reabilitação de edifícios.

De acordo com o processo de tomada de decisão apresentado, a análise das possíveis soluções deve ser feita de acordo com os requisitos de decisão definidos, para que se possa, de acordo com as informações disponíveis, decidir sobre quais tecnologias melhor atendem às necessidades.

O próximo capítulo é dedicado às tecnologias construtivas passíveis de serem empregadas para a reabilitação de edifícios. Elas serão analisadas de acordo com os requisitos estabelecidos, buscando-se indicar aquelas com maior potencial de utilização em diferentes situações de reabilitação. 


\section{TECNOLOGIAS CONSTRUTIVAS PARA A REABILITAÇÃO DE EDIFÍCIOS}

Nas intervenções de melhoria de um edifício existente, como destacado, usualmente são utilizadas as mesmas tecnologias construtivas empregadas na construção de um edifício novo. Em alguns casos, o emprego dessas tecnologias na reabilitação pode ser realizado com eficiência, ou porque as interfaces com a construção existente são reduzidas ou porque são compatíveis. Contudo, algumas tecnologias, para serem implantadas em um edifício existente, podem requerer atenção especial, sobretudo às interfaces. Por isso, a seleção de tecnologias e de métodos construtivos a serem empregados na reabilitação é de grande importância e pode contribuir para o sucesso ou fracasso de um empreendimento deste tipo.

Ao se levantar a possibilidade de intervenção em um edifício, visando à melhoria do seu grau de sustentabilidade, deve-se analisar quais são os fatores fundamentais para o sucesso e a viabilidade do empreendimento. Hestnes e Kofoed (2002) citam a importância de se analisar cada caso, e definem alguns critérios, dentre os quais:

- A escolha das tecnologias deve ser baseada nas características específicas de cada edifício;

- A combinação de tecnologias deve ser cuidadosamente analisada para evitar o uso de diferentes medidas que produzem o mesmo resultado, sem impacto no desempenho da operação, mas aumentando os custos da reabilitação;

- Em regiões de clima quente, onde a demanda por resfriamento é alta, técnicas de resfriamento passivas podem resultar em reduções significativas no uso de energia para esse fim;

- Em regiões de clima frio, o isolamento do ambiente interno e o uso do aquecimento por irradiação solar são fatores importantes para a redução do consumo energético; 
- Muitos edifícios possuem problemas operacionais, como o controle ineficiente da ventilação e dificuldade para manter a temperatura do ambiente agradável. Nesses casos, a automação do controle de temperatura é uma alternativa que pode proporcionar grandes reduções no consumo de recursos.

De acordo com Devecchi (2010), os recursos consumidos, bem como os resíduos gerados nos edifícios se devem a diversos fatores que incluem o tipo de uso do mesmo, ou seja, se é comercial, industrial, residencial; assim como sua localidade e as características dos seus usuários. Em países de clima frio, o foco da redução do consumo de recursos é a energia consumida para o aquecimento dos ambientes; nesses casos, a redução do consumo de energia está diretamente relacionada a um sistema eficiente de isolamento térmico para a redução de troca de calor, além do aproveitamento da irradiação solar para aquecimento dos ambientes.

Contudo, em clima mais ameno, autores como Santamouris (2002) e Hestnes e Kofoed (2002) citam a ventilação e o sombreamento dos ambientes como fatores que garantem o conforto dos usuários, sem gastos com energia. Segundo os autores, essas alternativas remetem a uma maior intervenção no edifício, contudo, proporcionam vantagens como menor dependência de sistemas mecânicos e menores custos com manutenção.

Desta forma, verifica-se que as ações de reabilitação para a redução do consumo energético - quando não são relacionadas aos sistemas elétricos, de aquecimento de água ou a utilização de recursos renováveis - ocorrem pelo uso de técnicas passivas, ou seja, intervenções nos demais subsistemas do edifício que buscam o conforto dos usuários por meios naturais, como o isolamento térmico, a ventilação e a iluminação naturais (SANTAMOURIS e DASCALAKI, 2002).

Além disto, na pesquisa sobre a análise de custos para a reabilitação de edifícios realizada por Marques de Jesus (2008), os sistemas prediais e a vedação foram identificados como os que mais impactam nos custos de reabilitação. No caso dos sistemas elétricos, o autor ressalta que, na grande 
maioria das vezes, há necessidade de substituição completa em função de sua obsolescência, dada a idade dos edifícios. Com relação aos vedos, o autor afirma que os custos variam muito, tendo identificado percentuais de $2,44 \%$ a $11,64 \%$ do custo direto, variando, principalmente, em função da mudança de uso do edifício e de seu estado de conservação. O autor ressalta, porém, que ainda que o percentual de participação do vedo seja reduzido no custo global, devido a sua interferência com os demais subsistemas do edifício - esquadrias, revestimentos e sistemas prediais - os custos destes últimos são influenciados diretamente pela definição do tipo de tecnologia de vedo empregada.

De acordo com a literatura estudada, a maioria das intervenções que visam à redução do consumo de recursos, é realizada nos sistemas prediais e nas vedações, seja para o isolamento térmico de ambientes, para permitir a ventilação e iluminação por meios naturais, ou através da substituição dos sistemas prediais antigos por outros mais eficientes.

\subsection{Levantamento de alternativas Tecnológicas sustentáveis para reabilitação}

Dentre as inúmeras tecnologias construtivas existentes, neste capítulo estão descritas algumas, que ao mesmo tempo possuem vantagens para a reabilitação e contribuem para o aumento do grau de sustentabilidade da construção e operação de edifícios.

Com base nas características e particularidades da reabilitação anteriormente descritas, foram identificados os subsistemas que possuem maior possibilidade de intervenção na reabilitação e que, pela sua substituição, permitem ao edifício uma melhoria da sustentabilidade ambiental. Foi realizado um levantamento das principais tecnologias construtivas utilizadas em edifícios sustentáveis, para identificar as que, de alguma forma, possibilitam o aumento do desempenho social, econômico e principalmente ambiental,destes edifícios.

Esse levantamento de tecnologias foi feito com base em documentos, como o Energy-efficient refurbishment of existing housing (ENERGY SAVING TRUST, 2007), que lista oportunidades para a melhoria da eficiência energética através 
de intervenções em edifícios existentes, como o isolamento de paredes internas e externas, ventilação, iluminação de baixo consumo energético e tecnologias renováveis. Outro documento, o Existing building survival strategies (ARUP, 2009), lista 195 iniciativas que visam a redução dos custos de operação de edifícios, entre as quais são apresentadas tecnologias construtivas que contribuem para esta redução.

O Buildings energy data book, do departamento de energia dos Estados Unidos (U.S. DEPARTMENT OF ENERGY, 2009) apresenta informações sobre características e desempenho de tecnologias e materiais, além da sua utilização em edificações dos Estados Unidos.

Santamouris e Dascalaki (2002) apresentam tecnologias passivas para a melhoria do desempenho energético e do ambiente interno dos edifícios.

Das diversas tecnologias identificadas, foram selecionadas algumas, que são apresentadas no item 4.2 .

As tecnologias foram caracterizadas para que, empregadas em edifícios existentes, possam atender às novas necessidades de transformá-los em ambientes mais sustentáveis. Por meio destas tecnologias, e com intervenções em diferentes níveis, paralelamente à análise de outros fatores que influenciam no desempenho da edificação, o empreendedor poderá realizar uma reabilitação com benefícios para o meio ambiente, melhorando as condições de conforto para o usuário, além de reduzir os custos de operação do edifício.

A caracterização das tecnologias foi feita com base nos requisitos de sustentabilidade definidos como principais para uma reabilitação, conforme apresentado no item 3.4, a fim de subsidiar a escolha daquelas que melhor atendem às demandas de uma reabilitação sustentável.

Os subsistemas estão divididos da seguinte forma:

- Vedação externa: tecnologias relacionadas a vedação de fachada, vedos externos, esquadrias de janela, elementos de sombreamento, entre outros (Quadro 4.1, Quadro 4.2); 
- Vedação interna: tecnologias para vedação interna vertical e horizontal, como elementos de vedo vertical, revestimentos de piso e forros (Quadro 4.3, Quadro 4.4, Quadro 4.5, Quadro 4.6);

- Instalações elétricas e de ar condicionado: tecnologias relacionadas à iluminação e climatização (Quadro 4.10, Quadro 4.11);

- Instalações hidráulicas e sanitárias: sistemas prediais de água, esgoto, reuso de água e sistemas de redução de consumo de água (Quadro 4.7, Quadro 4.8, Quadro 4.9);

- Sistemas de geração de energia: tecnologias para geração de calor e de energia elétrica (Quadro 4.12).

As tecnologias apresentadas neste capítulo foram selecionadas com base em estudos que enfatizam a importância da redução dos impactos ambientais na construção civil. Portanto, cada tecnologia identificada está vinculada principalmente aos benefícios relacionados à sustentabilidade que propicia.

É importante ressaltar que as tecnologias a serem aplicadas e suas interfaces com 0 edifício existente devem garantir 0 atendimento aos requisitos apresentados, de acordo com as necessidades dos usuários. Além disto, a seleção da tecnologia a ser utilizada deve levar em conta o custo global de sua aplicação durante todo o ciclo de vida do empreendimento, tanto dos materiais utilizados, quanto da utilização, manutenção e substituição das mesmas.

$\mathrm{Na}$ caracterização de cada tecnologia, apresentada no item 4.2, não foram identificados os custos. Foi considerado que, como há variação de custos, principalmente relacionada às condições econômicas e tecnológicas ao longo do tempo; às características específicas de cada projeto de reabilitação; e às condições de localização dos empreendimentos nas diferentes regiões do país; os custos relacionados a cada tecnologia não seriam significativos para os objetivos do presente trabalho.

De forma a homogeneizar as informações relacionadas às tecnologias, sua caracterização envolve: descrição das tecnologias; requisitos de 
sustentabilidade relacionados e seus impactos na reabilitação; descrição dos componentes; características da aplicação na reabilitação de edifícios; e as interfaces com os demais subsistemas. Por fim, são apresentadas as fontes utilizadas para a caracterização para eventuais consultas com vistas a se aprofundar no tema.

Algumas informações relativas à tecnologia não puderam ser descritas uma vez que se alteram em função das diferentes situações de projeto em que são utilizadas, ou por falta de informação no mercado e em documentos técnicos.

\subsection{Tecnologias sustentáveis: características e aplicação na reabilitação de edifícios}

Para a apresentação das características de cada tecnologia, foram elaboradas fichas que descrevem os aspectos de cada uma delas, de forma a facilitar a visualização e entendimento de cada aspecto.

Após uma descrição sobre a tecnologia, são apresentados os impactos de cada tecnologia nos requisitos de sustentabilidade definidos no capítulo 3 . Estes impactos foram definidos de forma qualitativa a partir da bibliografia consultada, de forma a auxiliar na ponderação destes requisitos para a tomada de decisão. Em alguns casos, esse impacto depende dos componentes a serem utilizados, portanto, podem sofrer alterações. Além do grau de impacto dos requisitos de sustentabilidade, define-se se estes são positivos ou negativos, sendo que para alguns casos, estes são deixados em branco, como no caso de um forro suspenso, que dependendo do material utilizado, o impacto da gestão de resíduos pode ser positivo ou negativo.

$\mathrm{Na}$ ficha são também descritas as características técnicas dos componentes utilizados, relacionadas ao tipo de componente e sua função. Além disso, apresentam-se considerações para a utilização da tecnologia na reabilitação de edifícios, suas vantagens e desvantagens. Por fim, são relacionados os subsistemas que possuem interface com a tecnologia descrita. 


\subsection{Considerações finais}

Este capítulo apresenta as tecnologias sustentáveis passíveis de serem utilizadas na reabilitação de um edifício. No processo de tomada de decisão proposto no item 3.1.2, o levantamento de tecnologias faz parte da etapa 4, ou seja, a formulação das alternativas de decisão.

Das tecnologias a serem consideradas em uma reabilitação, deve-se priorizar aquelas que possuem maior compatibilidade com a construção existente. Uma tecnologia de vedação leve, por exemplo, pode evitar sobrecargas na estrutura e, consequentemente, evitar a necessidade de reforços estruturais. Da mesma forma, um revestimento não aderido pode evitar a necessidade de retirada de componentes da vedação, mantendo-os incorporados à construção existente; essa ação minimizaria o resíduo gerado.

Assim, para a escolha das tecnologias apresentadas neste capítulo, foram considerados os principais subsistemas que sofrem intervenções em uma reabilitação: vedações verticais, horizontais, instalações elétricas, hidráulicas e de ar condicionados, bom como sistemas de geração de energia.

Para isto, algumas estratégias foram consideradas, como:

- Causar baixo impacto ao edifício existente, por exemplo, com a utilização de elementos leves, para não sobrecarregar a estrutura existente;

- Minimizar a geração de resíduos, por exemplo, aproveitando os elementos existentes, evitando a remoção de materiais incorporados ao edifício;

- Evitar embutimento de instalações: optar pela utilização de forros, shafts, e vãos que permitam a passagem de instalações;

- Considerar a sustentabilidade do uso e operação do edifício;

- Priorizar a utilização de fontes de energia renováveis. 
É importante salientar que o propósito deste item é apresentar e caracterizar algumas das muitas tecnologias que podem ser usadas na reabilitação. Para cada tecnologia são apresentadas, principalmente, as informações que não dependem do contexto no qual serão inseridas. Informações relativas à viabilidade econômica, por exemplo, dependem do ambiente em que a tecnologia é aplicada, ou seja, das características locais e de mercado, bem como das características originais do edifício a ser reabilitado.

Esse processo de caracterização das tecnologias visando à reabilitação deve ser um método das empresas envolvidas principalmente com a elaboração de projetos, de tal maneira a constituir um banco de dados. Para isto, uma possível continuidade deste trabalho seria a elaboração de um banco de dados, no qual informações importantes sobre o ciclo de vida de cada tecnologia seriam documentadas, de forma a auxiliar na escolha de tecnologias para a reabilitação.

Assim, para a aplicação dessas tecnologias como alternativas no processo de tomada de decisão proposto no capítulo 5 , deve ser feito um levantamento detalhado de informações de cada tecnologia, quando aplicadas ao contexto específico de uma reabilitação. 


\section{REVESTIMENTOS NÃO ADERIDOS}

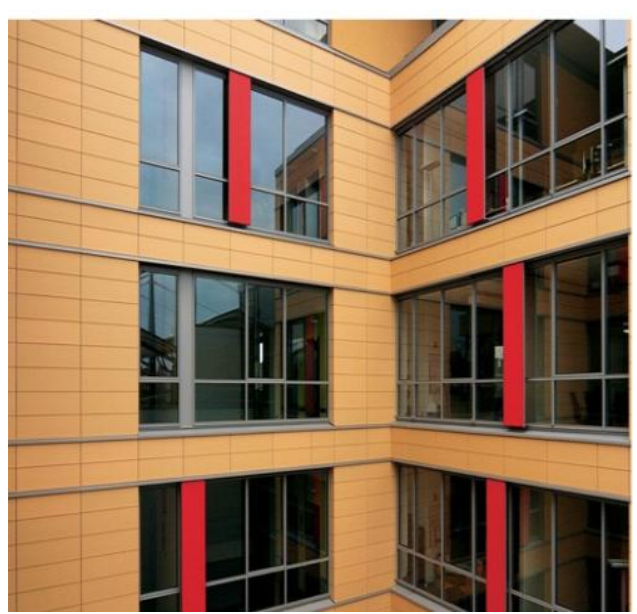

Fachada com revestimento não aderido. Fonte: www.keragail.com.br

\section{Descrição da tecnologia}

Os revestimentos não aderidos são componentes fixados por dispositivos a uma estrutura de suporte (parede de alvenaria, por exemplo).
Impacto dos requisitos de sustentabilidade

Conforto térmico: esta tecnologia proporciona uma redução da transmitância térmica ao ambiente interno devido à bolsa de ar entre a fachada e o vedo.

Conforto acústico: da mesma forma que o conforto térmico também proporciona uma redução sonora devido à bolsa de a entre a fachada e o vedo. Contudo, para o cálculo dos níveis de redução sonora, deve-se considerar os demais componentes da fachada, como as esquadrias.

Gestão de resíduos: com a utilização desta tecnologia, pode se evitar a geração de resíduos devido à possibilidade de fixação do revestimento diretamente à fachada pré existente, evitando a demolição desses componentes.

Relação com o entorno: a alteração do tipo de revestimento da fachada pode gerar um impacto visual, relacionado à mudança da aparência do edifício.

Compatibilidade com a construção existente : por serem fixados por dispositivos, aceitam possíveis imperfeições da base.

Otimização do desempenho energético: devido à redução da transmitância térmica, pode proporcionar uma redução no consumo energético para aquecimento ou resfriamento dos ambientes.

\section{Características técnicas (componentes) \\ Revestimento Podem ser utilizados diferentes componentes como placas de rocha, chapas metálicas, componentes cerâmicos, entre outros. \\ Dispositivos de Devem resistir aos esforços que estarão submetidos e permitir a livre movimentação das placas, evitando a fixação transmissão excessiva de tensões às mesmas. \\ Deve-se dar preferência a utilização de dispositivos de fixação de aço inoxidável (a associação de metais com diferentes potenciais eletroquímicos pode resultar em corrosão galvânica). \\ Selantes \\ Devem ser resistentes a agentes atmosféricos e produtos de limpeza, além de apresentar boa aderência e não causar danos às placas.

Os revestimentos não aderidos, fixados por dispositivos ou estrutura de apoio, permitem o revestimento do edifício reabilitado sem a necessidade de intervenções na estrutura ou vedação existentes.

Pequenas correções de alinhamento e prumo podem ser realizadas, sem que haja demolição do elemento de vedação existente. Alguns critérios relacionados à tecnologia:

- estanqueidade à agua da chuva;

- transmitância térmica;

- índice de redução sonora.

\section{Interferência com outros subsistemas}

Vedação externa e estrutura, que deverão sustentar o novo elemento;

Esquadrias, que foram executadas com base na referência do revestimento antigo, exigindo-se um elemento de arremate do vão entre o novo revestimento e o peitoril existente.

Referências blibliográficas relacionadas a esta tecnologia

Gyotoku (2006)

Souza (2008)

Quadro 4.1 - Revestimentos não aderidos (vedação externa). 


\section{FACHADA CORTINA DE VIDRO}

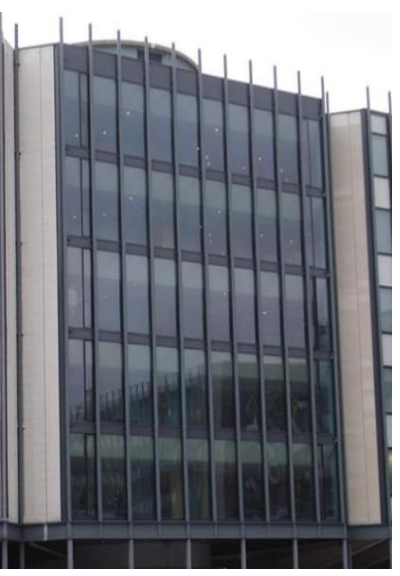

Fachada cortina de vidro. Fonte: Oliveira (2009) Descrição da tecnologia

Pode-se definir fachada cortina como "esquadrias interligadas e estruturadas com função de vedação, que formam um sistema contínuo, que se desenvolve no sentido da altura e/ou largura do edifício, sem interrupção, por pelo menos dois pavimentos" (ABNT NBR 10821-1:2011). O princípio é a fixação de uma estrutura metálica à estrutura do edifício que serve para fixar componentes como vidros, chapas metálicas, entre outros.
Impacto dos requisitos de sustentabilidade

Conforto térmico: devido ao fato de grande parte da área da fachada ser envidraçada, a irradiação solar pode gerar um aumento da temperatura do ambiente interno do edifício.

Conforto visual: devido ao fato de grande parte da área da fachada ser envidraçada, o índice de iluminação natural é alto.

Conforto acústico: a vedação externa é responsável pela redução sonora do ambiente externo para o interior do edifício. Assim, o conforto acústico está relacionado, principalmente, às características dos vidros empregados.

Gestão de resíduos: para a implantação desta tecnologia, pode ser necessário demolir parte da vedação existente.

Relação com o entorno: a alteração do tipo de revestimento da fachada pode gerar um impacto visual, relacionado à mudança da aparência do edifício.

\section{Compatibilidade com a construção existente: por serem} fixados por dispositivos, aceitam possíveis imperfeições da estrutura em que será fixada.

Otimização do desempenho energético: fatores como o aumento da irradiação solar e do índice de iluminação natura podem impactar no desempenho energético do edifício.

\section{Características técnicas (componentes)}

Estrutura De aço carbono, de alumínio ou de aço inoxidável, são fixados à estrutura principal por meio de

Estrutura de suporte dispositivos de fixação que permitem compensar desvios de alinhamento entre as estruturas.

\begin{tabular}{|c|c|c|}
\hline \multirow{4}{*}{ Vidros } & $\begin{array}{c}\text { Vidro } \\
\text { termoabsorvente }\end{array}$ & $\begin{array}{l}\text { Vidro plano, colorido através da adição de óxidos, visando a proteção solar. Sua } \\
\text { superfície, quando exposta ao sol, pode chegar a } 60^{\circ} \mathrm{C} \text {. }\end{array}$ \\
\hline & Vidro laminado & $\begin{array}{l}\text { Formado por uma ou mais placas de vidro plano intercaladas por uma película } \\
\text { polimérica incolor ou colorida. É considerado vidro de segurança pois, ao quebrar, } \\
\text { continua aderido à película, retendo os fraqmentos. }\end{array}$ \\
\hline & Vidro refletivo & $\begin{array}{l}\text { Recebe uma camada de óxidos metálicos em uma de suas faces, conferindo um } \\
\text { aumento no seu grau de reflexão. }\end{array}$ \\
\hline & Vidro insulado & $\begin{array}{l}\text { Vidro duplo, consiste em lâminas intercaladas com gases inertes (como argônio ou } \\
\text { criptônio). Essa cavidade entre os vidros funciona como isolamento acústico, além } \\
\text { de imnedir as trocas de calor nor conndıcãn. }\end{array}$ \\
\hline Selantes & \multicolumn{2}{|c|}{$\begin{array}{l}\text { Constituídos de materiais como silicone, poliuretanos, polissulfetos, acrílicos, entre outros, devem resistir } \\
\text { à esforços solicitantes e acomodar movimentações previstas. }\end{array}$} \\
\hline
\end{tabular}

\section{Utilização na Reabilitação de Edifícios}

Exerce função de vedação e, desta forma, a aplicação deste elemento em uma reabilitação implica em uma intervenção mais profunda no edifício, podendo gerar a necessidade de demolição dos elementos antigos de vedação externa.

Alguns critérios relacionados à tecnologia:

- nível de sombreamento dos ambientes internos (através dos vidros);

- estanqueidade à agua da chuva (principalmente através do selante);

- transmitância térmica (principalmente através dos vidros);

- ventilação dos ambientes (se previstos dispositivos para abertura)

- índice de redução sonora;

- nível de iluminação natural (através dos vidros).

\section{Interferência com outros subsistemas}

Estrutura, que deverá suportar o elemento;

Elementos de vedação interna, como paredes guarda corpos e forros, em que as interfaces devem ser previstas em detalhes no projeto.

\section{Referências blibliográficas relacionadas a esta tecnologia}

Caram (2002)

Oliveira (2009)

Schiochet (2009)

ABNT NBR 10821-1:2011

\section{Quadro 4.2 - Fachada cortina de vidro (vedação externa).}




\section{PAREDE EM GESSO ACARTONADO}

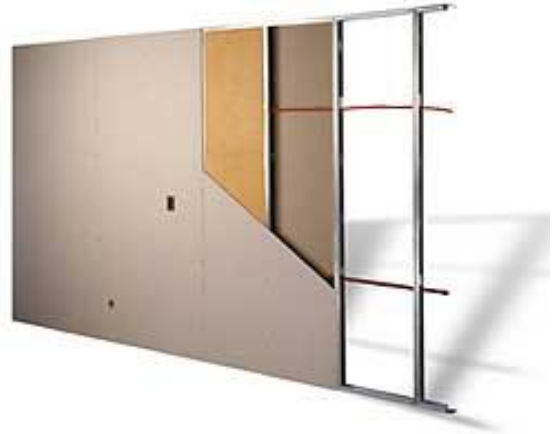

Componentes da parede em gesso acartonado. Fonte: www.placo.com.br

\section{Descrição da tecnologia}

É o conjunto de componentes formado por chapas de gesso acartonado, estrutura de perfis de aço, acessórios de fixação e insumos, destinados a atender determinadas funções de compartimentação, as quais definem e limitam verticalmente os ambientes internos dos edifícios controlando o fluxo de agentes solicitantes, cumprindo as exigências dos usuários (ABNT NBR 15758).

Características técnicas (componentes)

Chapas de gesso Chapas fabricadas industrialmente mediante um processo de laminação contínua de uma mistura de

Chapas de gesso gesso, água, e aditivos entre duas lâminas de cartão, onde é virada sobre as bordas longitudinais e colada acartonado galvanizado

Isolamento térmico e sobre a outra (NBR 14715).

Perfis formados a frio com função de suporte das chapas.

Material isolante, normalmente em lã mineral, inserida no interior da parede. A correta instalação deste acústico

Fitas e massa para Componentes para o tratamento das juntas entre chapas. junta

Dispositivos de $\quad$ Parafusos utilizados para fixar as chapas aos perfis e os perfis à estrutura de suporte. fixação

Por ser uma vedação leve, possibilita o aproveitamento da estrutura existente, reduzindo a necessidade de se realizar reforços. Permite a passagem de instalações em seu interior, sem quebras e com mais produtividade.

Se adéquam a qualquer espessura de parede por ser uma vedação oca estruturada por perfis. Desta forma, esta solução se adéqua também a edifícios antigos de alvenaria resistente, que possuem paredes de grandes espessuras.

Alguns critérios relacionados à tecnologia:

- transmitância térmica (através das mantas isolantes);

- índice de redução sonora (através das mantas isolantes).

\section{Interferência com outros subsistemas}

Instalações prediais, com o embutimento destas nas paredes de gesso acartonado facilitada devido ao espaço entre as chapas e à estrutura de perfis.

Estrutura e elementos de vedação como alvenaria, devendo-se ter atenção especial nestas interfaces para evitar fissuras. Componentes de acabamento, móveis, bancadas suspensas, entre outros, devendo-se prever reforços na parte interna da vedação devido à baixa resistência.

\section{Referências blibliográficas relacionadas a esta tecnologia}

Reabilita (2007)

Taniguti (1998)

ABNT NBR 14715 - Chapas de gesso acartonado - Requisitos

ABNT NBR 14716 - Chapas de gesso acartonado - Verificação das características geométricas

ABNT NBR 14717 - Chapas de gesso acartonado - Determinação das características físicas

ABNT NBR 15217 - Perfis de aço para sistemas de gesso acartonado - Requisitos

\section{Quadro 4.3 - Parede em gesso acartonado (vedação interna).}




\section{BLOCO DE CONCRETO CELULAR AUTOCLAVADO}

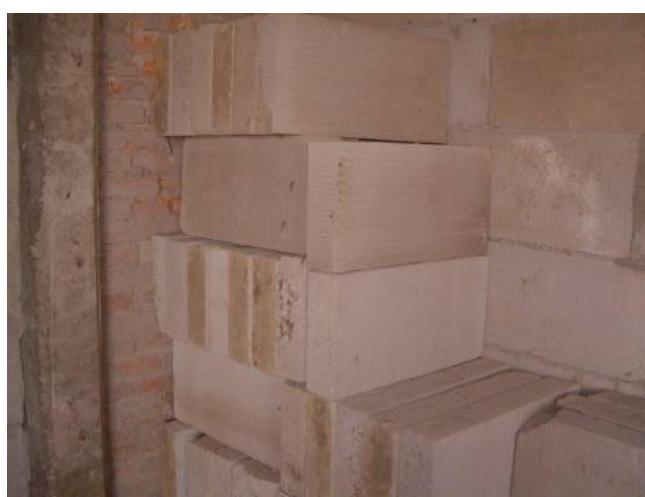

Impacto dos requisitos de sustentabilidade

Conforto térmico: esta tecnologia gera impacto no conforto térmico com relação à transmitância térmica entre ambientes internos.

Conforto acústico: esta tecnologia gera impacto no conforto acústico com relação à redução sonora entre ambientes internos.

Gestão de resíduos: devido ao tamanho dos blocos e à possível falta de modulação em relação à dimensão da parede a ser executada, a geração de resíduos durante a reabilitação pode ser grande.

Compatibilidade com a construção existente : por ser uma vedação leve, permite aumentar a área de paredes sobre a estrutura existente, sem a necessidade de reforços estruturais.

Bloco de concreto celular autoclavado. Fonte: REABILITA, 2007. Descrição da tecnologia

É um produto inorgânico que, apesar de ter baixa densidade superficial, apresenta adequada capacidade mecânica, além de ser um razoável isolante térmico e acústico e apresentar elevada resistência ao fogo e aos microorganismos.

\section{Características técnicas (componentes)}

Blocos com estrutura celular, constituída por cerca 60 a $70 \%$ de ar, incorporado ao bloco.

Otimização do desempenho energético: devido ao isolamento térmico dos ambientes, pode gerar algum impacto no desempenho energético.

\section{Utilização na Reabilitação de Edifícios}

Além da leveza e da facilidade de corte, a grande vantagem é a semelhança construtiva com o sistema tradicional de assentamento de blocos cerâmicos, permitindo utilizar a experiência da mão de obra existente no país.

Alguns critérios relacionados à tecnologia:

- transmitância térmica;

- índice de redução sonora.

\section{Interferência com outros subsistemas}

O potencial de racionalização construtiva dos blocos de concreto celular é representado pela leveza, grande dimensão, boa textura para a aplicação de revestimentos aderidos, uniformidade dimensional e facilidade de corte.

Instalações elétricas e hidráulicas, podem ser facilmente embutidas, e a interface entre a alvenaria e a estrutura é tratada da mesma forma que a alvenaria de blocos cerâmicos ou de concreto

\section{AGO (2003)}

ACCOA (2003)

PATH (2001)

COSTA e FRANCO (1996)

\section{Quadro 4.4 - Bloco de concreto celular autoclavado (vedação interna).}




\section{FORRO SUSPENSO}

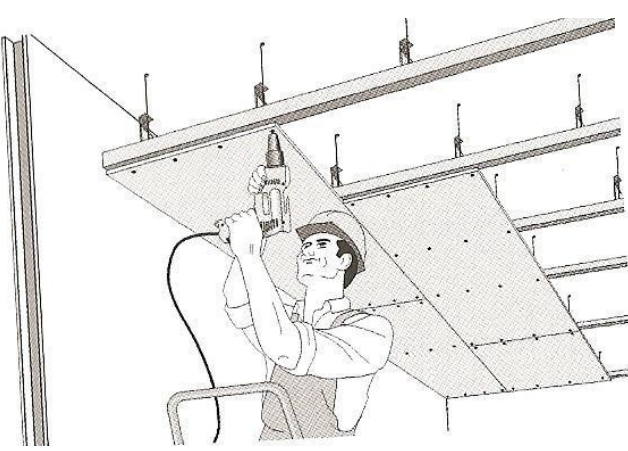

Exemplo de aplicação de forro estruturado. Fonte: www.drywall.com.br
Impacto dos requisitos de sustentabilidade

Conforto acústico: esta tecnologia gera impacto no conforto acústico com relação à redução sonora entre andares e em relação às instalações localizadas etre o forro e a laje. $A$ redução sonora está relacionada, principalmente, às características do material isolante empregado.

Gestão de resíduos: os impactos relacionados a este requisito dependem do tipo de material utilizado.

\section{Compatibilidade com a construção existente: caso o pé} direito do edifício possibilite a passagem de instalações entre o forro e a laje, a execução das instalações prediais é facilitada e pode-se reduzir as intervenções, como o embutimento de instalações nas vedações existentes.

\section{Descrição da tecnologia}

Consiste no revestimento da face inferior da laje ou de telhados de modo a constituir a superfície superior de um ambiente fechado. Podem ser classificados de acordo com a sua fixação: forros aramados, estruturados, removiveis.

\begin{tabular}{|c|c|}
\hline \multicolumn{2}{|c|}{ Características técnicas (componentes) } \\
\hline $\begin{array}{l}\text { Componentes de } \\
\text { fechamento }\end{array}$ & $\begin{array}{l}\text { Diferentes materiais podem ser utilizados para a sua execução, como madeira, placas de gesso, gesso } \\
\text { acartonado, PVC, fibra mineral, entre outros }\end{array}$ \\
\hline Perfis de suporte & Perfis com função de suporte do fechamento, podendo ser de aço galvanizado. \\
\hline $\begin{array}{l}\text { Isolamento térmico e } \\
\text { acústico }\end{array}$ & $\begin{array}{l}\text { Mantas isolantes, normalmente em lã mineral, inseridas entre o forro e a laje. A correta instalação deste } \\
\text { componente deve garantir o cobrimento de toda a área do forro. }\end{array}$ \\
\hline $\begin{array}{l}\text { Dispositivos de } \\
\text { fixação }\end{array}$ & $\begin{array}{l}\text { Parafusos utilizados para fixar componentes de fechamento aos perfis, e pendurais para fixar os perfis à } \\
\text { estrutura de suporte. }\end{array}$ \\
\hline
\end{tabular}

A utilização de forros suspensos permite abrigar instalações elétricas e hidráulicas, possibilitando flexibilidade para a passagem de tubulações, além de facilidade de manutenção.

A utilização de forro suspenso em um edifício existente fica limitada ao tamanho do pé direito deste edifício.

Alguns critérios relacionados à tecnologia:

- transmitância térmica;

- índice de redução sonora.

\section{Interferência com outros subsistemas}

Instalações prediais, com o embutimento destas facilitada devido à vedação;

lluminação artificial;

Estrutura, que suporta o forro;

Vedações, em que as interfaces devem ser previstas em detalhes no projeto, pela utilização de tabicas, por exemplo.

\section{Quadro 4.5 - Forro suspenso (vedação interna)}




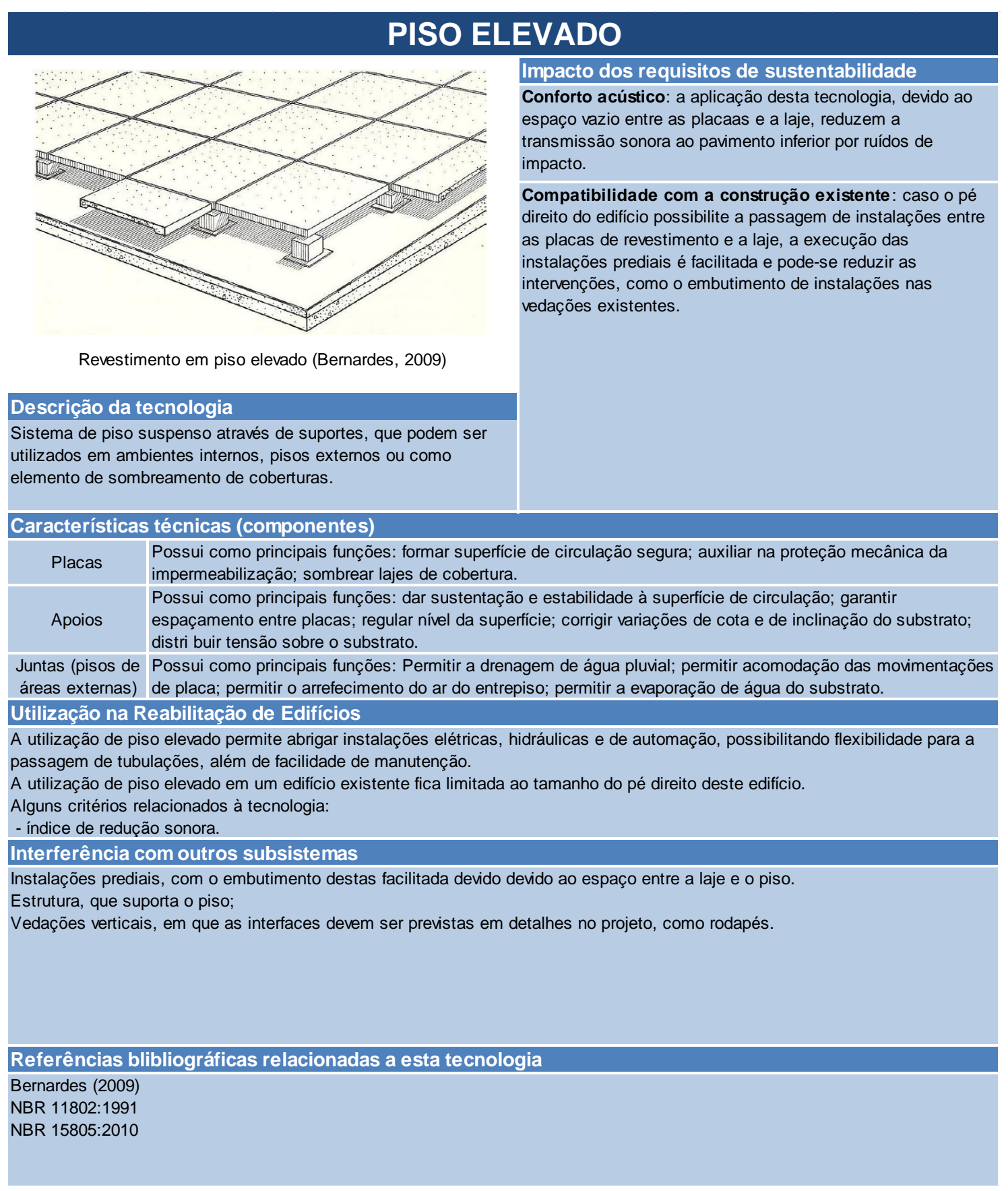

Quadro 4.6 - Piso elevado (vedação interna). 


\section{INSTALAÇÕES INTEGRADAS PRÉ MONTADAS}

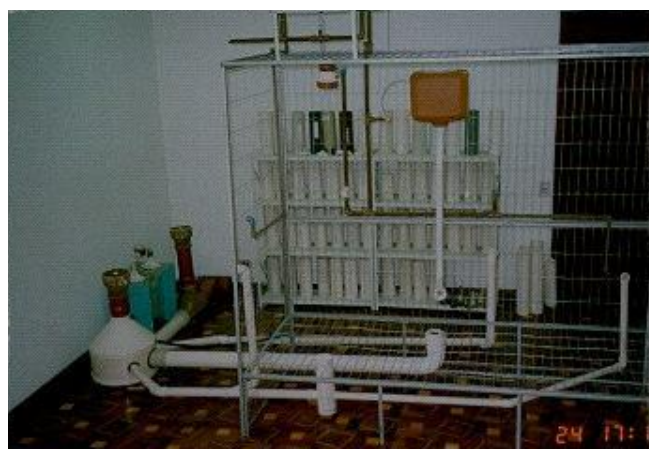

Exemplo de kit hidráulico. Fonte: REABILITA (2007)

\section{Descrição da tecnologia}

Nas instalações integradas pré montadas, as tubulações e conexões de um banheiro, por exemplo, são executadas por completo, formando "kits" que serão posicionados à frente da parede e, posteriormente "apaineladas", ou seja, fecha-se a parede e piso com painel específico para áreas molháveis.
Impacto dos requisitos de sustentabilidade

Gestão de resíduos: evita a demolição de vedações e retirada de possíveis enchimentos na laje, podendo, assim, manter os componentes das instalações antigas incorporados à edificação, porém sem qualquer função.

Otimização do uso da água: facilita a mudança das instalações por outras mais eficientes, além de facilitar a manutenção, no caso de vazamentos.

Compatibilidade com a construção existente : apesar de reduzir a área útil do ambiente, os kits podem ser instalados sem danos ou interferências às vedações existentes.

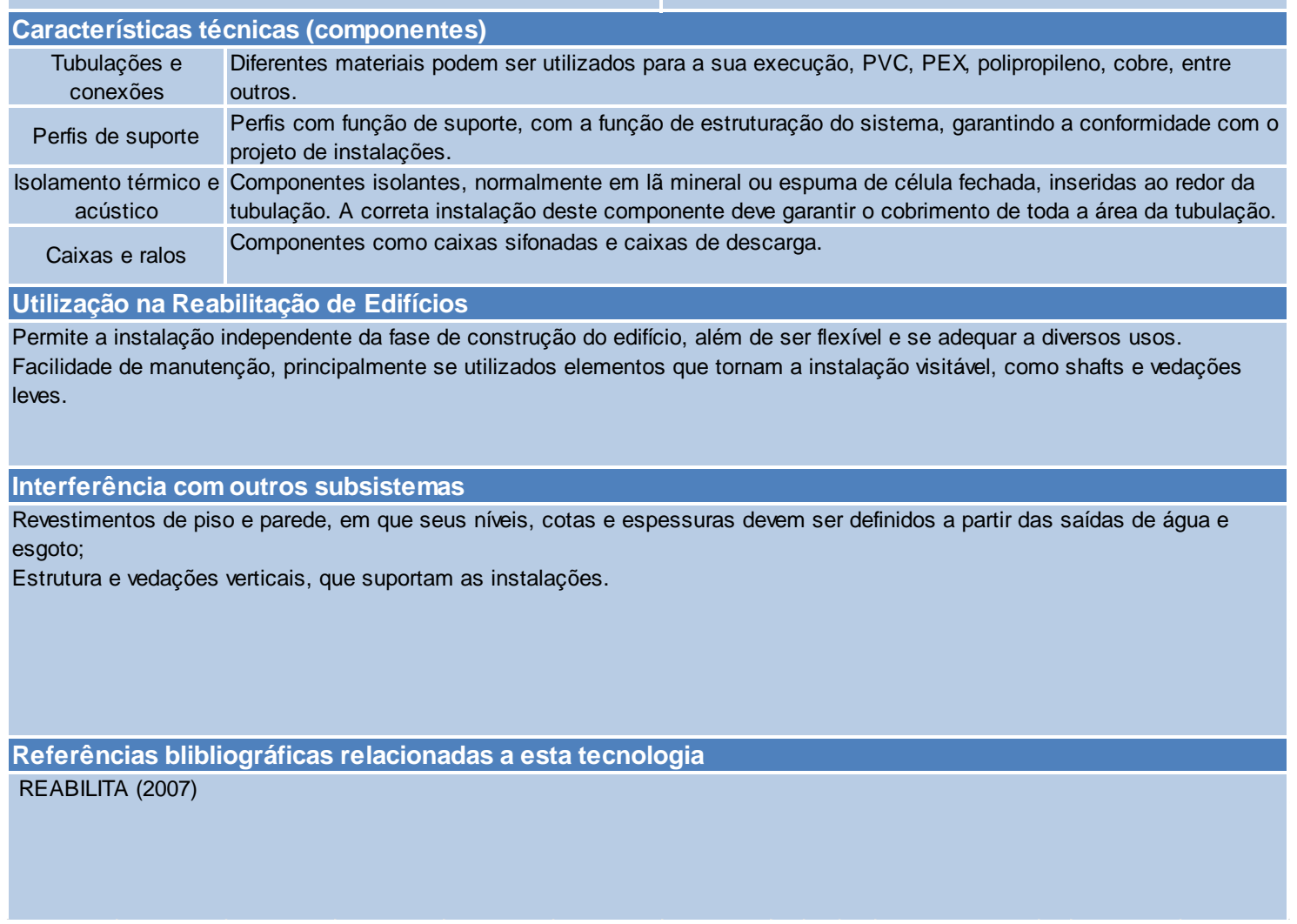

\section{Quadro 4.7 - Instalações integradas pré montadas (instalações hidráulicas).}




\section{TUBULAÇÃO DE POLIETILENO RETICULADO FLEXÍVEL (PEX)}

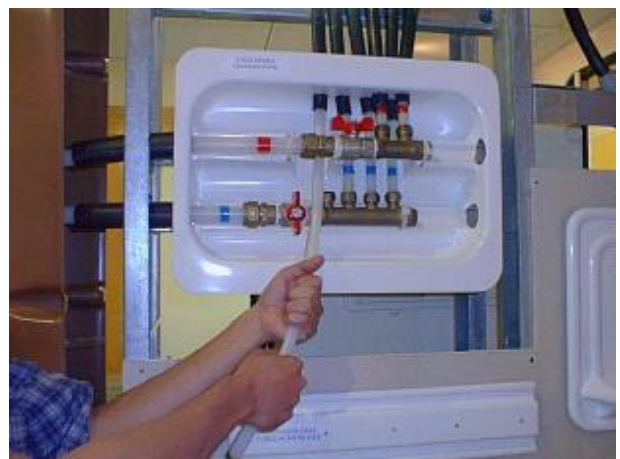

Central de distribuição de tubulação PEX. Fonte: www.pexdobrasil.com.br
Impacto dos requisitos de sustentabilidade

Gestão de resíduos: a manutenção das tubulações pode ser realizada sem a necessidade de quebra da vedação na qual está embutida.

Otimização do uso da água: por não necessitar de conexões em curvas, há menor risco de vazamentos.

Compatibilidade com a construção existente: as conexões utilizadas em ramais de distribuição são compatíveis com demais tipos de tubulação. Pela flexibilidade, torna-se mais facil a compatibilização com projetos de outros subsistemas do edifício.

\section{Descrição da tecnologia \\ Tecnologia para instalações hidráulicas que utiliza tubulação \\ flexível, eliminando a necessidade de utilização de conexões em}

curvas para mudanças de direção.

\section{Características técnicas (componentes)}

\begin{tabular}{|c|c|}
\hline Tubulação & $\begin{array}{l}\text { Componente de polietileno reticulado flexível, que conduz a água da caixa de distribuição até o ponto de } \\
\text { consumo. }\end{array}$ \\
\hline Conexões & $\begin{array}{l}\text { Componentes metálicos que, através de um sistema de roscas de fixação a frio, faz a junção entre as } \\
\text { tubulações. }\end{array}$ \\
\hline Tubo condutor & $\begin{array}{l}\text { Funciona como um guia ligando a caixa de distribuição até o ponto de consumo, sendo que a tubulação é } \\
\text { introduzida dentro do condutor. }\end{array}$ \\
\hline
\end{tabular}

O tubo PEX pode ser introduzido e retirado quando houver necessidade, de forma que se um vazamento é identificado, a tubulação pode ser substituída sem a necessidade de quebra da vedação. A substituição das tubulações antigas, de ferro fundido ou mesmo de PVC e cobre, pelo sistema PEX pode reduzir o risco de patologias, bem como facilitar a manutenção dos sistemas hidráulicos.

Comumente utilizada embutida em vedações de gesso acartonado, porém pode ser utilizada também em alvenaria ou forros. No gesso acartonado, as tubulações são inseridas no vão entre as chapas, com o ponto de alimentação fixo por montantes. Já na alvenaria, o tubo condutor deve ser embutido da mesma forma que um eletroduto flexível para que então a tubulação passe após a parede pronta.

\section{Interferência com outros subsistemas}

Revestimentos de piso e parede, em que seus níveis, cotas e espessuras devem ser definidos a partir das saídas de água e esgoto;

Estrutura e vedações verticais, que suportam as instalações.

\section{Referências blibliográficas relacionadas a esta tecnologia}

www.pexdobrasil.com.br

REABILITA (2007)

EN ISO 15875-1, Plastics piping systems for hot and cold water installations. Crosslinked polyethylene (PE-X). Part 1: General

EN ISO 15875-2, Plastics piping systems for hot and cold water installations. Crosslinked polyethylene (PE-X). Part 2: Pipes

EN ISO 15875-3, Plastics piping systems for hot and cold water installations. Crosslinked polyethylene (PE-X). Part 3: Fittings

\section{Quadro 4.8 - Tubulação de polietileno reticulado flexível (instalações hidráulicas).}




\section{SISTEMA DE ESGOTO A VÁCUO}

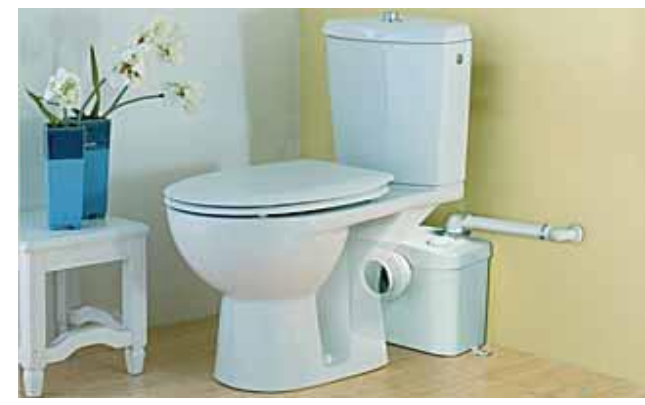

Figura 3.11 - Triturador de resíduos. Fonte: www.saniflo.co.uk Descricão da tecnolocia

Consiste no esgotamento de efluentes proveniente do esgoto primário e secundário de edificações através da utilização de "pressão negativa" ou pressão reduzida, gerada por bombas que ao retirarem a pressão atmosférica de dentro de uma rede de tubulações, produzem um diferencial de pressão de ar (vácuo), succionando os dejetos existentes dentro de uma pequena caixa de válvula de coleta de esgoto.

\section{Características técnicas (componentes)}

Bomba de vácuo Equipamento utilizado para reduzir a pressão dentro das tubulações

Triturador de resíduos Aparelho utilizado em vasos sanitários para que os resíduos possam passar pelas tubulações de diâmetro Triturador de resíduos reduzido.

$$
\text { Tubulação Elemento de condução do esgoto até a rede. }
$$

\section{Utilização na Reabilitação de Edifícios}

A principal vantagem deste sistema é a utilização de tubulações de menor diâmetro do que as tubulações convencionais de esgoto, além da independência da gravidade para a condução dos resíduos. Para a reabilitação de edifícios, nos quais o pé direito já está definido, esta pode ser uma solução para diversos problemas de interfaces entre os sistemas prediais hidráulicos e os demais subsistemas do edifício.

\section{Interferência com outros subsistemas}

Revestimentos, sendo que a utilização desta tecnologia reduz a necessidade de rebaixamento de forros e as tubulações podem ser embutidas no contrapiso.

\section{Referências blibliográficas relacionadas a esta tecnologia}

\section{www.saniflo.co.uk}

vacuum.jetsgroup.com

Devecchi (2010)

\section{Quadro 4.9 - Esgoto a vácuo (instalações hidráulicas).}




\section{AR CONDICIONADO VRV}

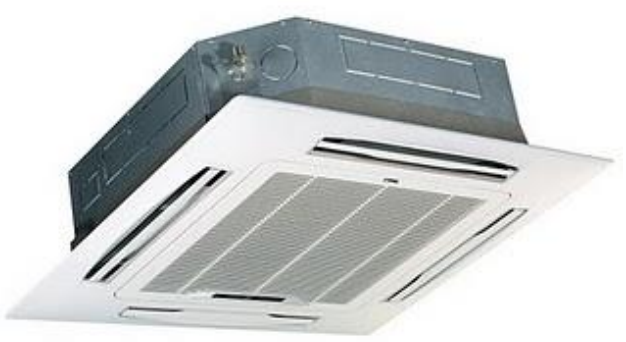

Impacto dos requisitos de sustentabilidade

Conforto térmico: é um sistema de climatização, e causa impacto diretamente ao conforto térmico, por controlar a temperatura dos ambientes.

Conforto acústico: durante o funcionamento pode gerar ruídos.

Compatibilidade com a construção existente: ao contrário do sistema de climatização central, que utiliza dutos para distribuição, o diâmetro da tubulação de gás refrigerante é reduzido (cerca de $2 \mathrm{~cm}$ ).

Otimização do desempenho energético: por permitir a Unidade evaporadora de um sistema VRV. Fonte: www.york.com definição individual em cada ambiente, pode reduzir o

\section{Descrição da tecnologia}

consumo total de energia.

\section{Sistema de climatização caracterizado pelo volume de}

refrigerante variável (VRV). Permite a definição da temperatura de cada ambiente individualmente, controlado por um sistema de automação que permite combinar múltiplas unidades internas em um só ciclo de refrigeração.

\section{Características técnicas (componentes)}

Unidades externas Componente responsável pela troca de calor entre o ambiente interno e o externo.

(condensadoras)

Unidades internas Componente responsável por succionar o ar quente existente no ambiente a ser climatizado, devolvendo-o (evaporadoras) refrigerado.

Tubulação frigorígena Tubulação que transporta o fluido refrigerante entre as unidades candensadoras e evaporadoras.

Utilização na Reabilitação de Edifícios

Flexibilidade para definição de critérios de conforto térmico dos ambientes, atendendo a ambientes contíguos de forma isolada.

O controle individual de temperatura pode gerar grande economia de energia em edifícios de escritório, nos quais as demandas térmicas por ambiente são diferentes.

Utiliza tubulações de menor diâmetro comparada a outros sistemas de ar condicionado, reduzindo a necessidade de grandes espaços de entreforro.

Baixo nível de ruído em relação aos demais sistemas de ar condicionado.

Alguns critérios relacionados à tecnologia:

- consumo de energia;

- capacidade térmica de refrigeração.

\section{Interferência com outros subsistemas}

Instalações elétricas;

Instalações hidráulicas, para a execução de drenos nas unidades;

Vedações externas, pois as condensadoras são instaladas na fachada ou cobertura do edifício:

Vedações internas, pois as evaporadoras são instaladas nos forros ou paredes.

\section{Referências blibliográficas relacionadas a esta tecnologia}

Daikin. Engineering data VRV III, heat pump. Ed. 34 - 645B, Daikin industries. Japão, 2006

\section{Quadro 4.10 - Ar condicionado VRV (instalações de ar condicionado).}




\section{Lâmpadas de LED}

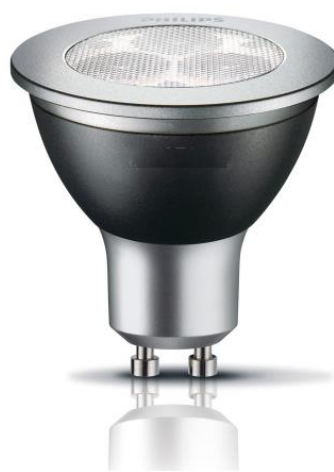

Impacto dos requisitos de sustentabilidade

Conforto visual: por ser uma iluminação artificial, gera impacto direto ao conforto visual.

Lâmpada tipo LED. Fonte: www.philips.com

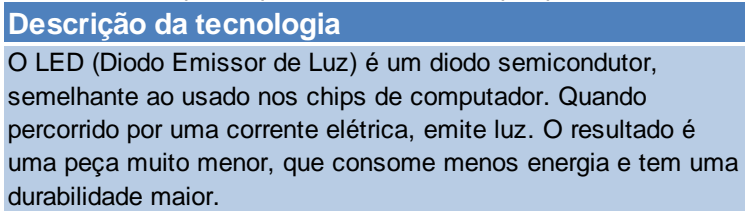

O LED (Diodo Emissor de Luz) é um diodo semicondutor, semelhante ao usado nos chips de computador. Quando percorrido por uma corrente elétrica, emite luz. O resultado uma peça muito menor, que consome menos energia e tem uma durabilidade maior.

\section{Características técnicas (componentes)}

Unidades externas Componente responsável pela troca de calor entre o ambiente interno e o externo.

Unidades internas Componente responsável por succionar o ar quente existente no ambiente a ser climatizado, devolvendo-o Tubulação frigorígena Tubulação que transporta o fluido refrigerante entre as unidades candensadoras e evaporadoras. Utilização na Reabilitação de Edifícios

Maior vida útil em relação a outras lâmpadas. Enquanto uma lâmpada comum tem vida útil de 1.000 horas e uma fluorescente de 7.500 horas, a LED rende entre 20.000 e 100.000 horas de uso ininterrupto.

Alguns critérios relacionados à tecnologia:

- índice de iluminação artificial;

- consumo de energia.

Interferência com outros subsistemas

Instalações elétricas;

Vedações internas, pois as evaporadoras são instaladas nos forros ou paredes. 


\section{PAINÉIS FOTOVOLTAICOS}

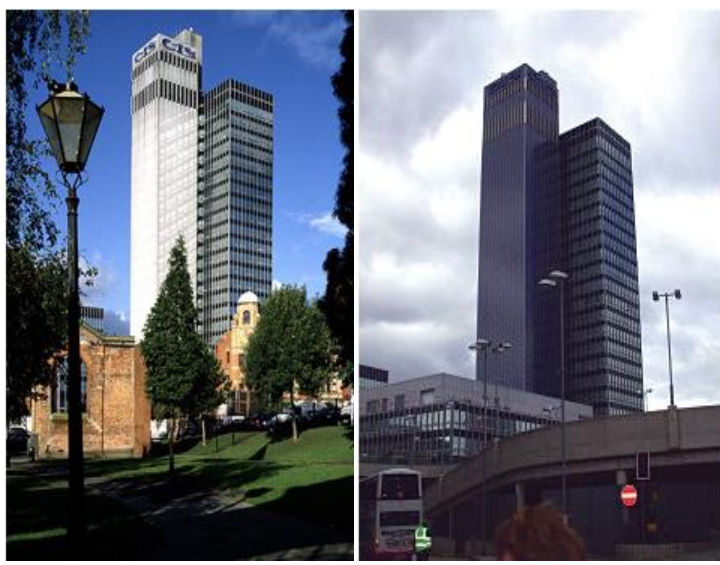

Impacto dos requisitos de sustentabilidade

Conforto visual: se usado como elemento de fachada,

contribui para a redução da iluminação natural ou para o sombreamento dos ambientes.

Relação com o entorno: pode gerar um impacto visual, relacionado à mudança da aparência do edifício.

Além disto, a geração de energia reduz a demanda de energia elétrica proveniente das concessionárias.

Compatibilidade com a construção existente: pode se fixado ao elemento de vedação, da fachada e da cobertura, ou à estrutura através de dispositivos.

Otimização do desempenho energético: não consome recursos do ambiente.

CIS Tower. Antes da reforma da torre de serviços (à esquerda) após a renovação da fachada em módulos PV.

\section{Descrição da tecnologia}

Conjunto de células constituídas por material semicondutor que convertem a luz solar em energia elétrica através de uma diferença de potencial. Estes painéis podem ser instalados em coberturas ou em fachadas.

\begin{tabular}{c|c|}
\hline Características técnicas (componentes) \\
\hline Painéis FV & $\begin{array}{l}\text { Painéis utilizados para gerar energia elétrica a partir de energia solar, compostos por gerador FV e } \\
\text { inversor. }\end{array}$ \\
\hline Gerador FV & Componente composto de células fotovoltaicas que capta a energia solar e transforma em energia elétrica \\
\hline Inversor & Transforma corrente contínua para corrente alternada. \\
\hline Utilização na Reabilitação de Edifícios
\end{tabular}

Apropriados para integração à envoltória da edificação, compondo a vedação do edifício.

As opções de produtos podem atender às diferentes demandas para a reabilitação de um edifício. Existem módulos rígidos e flexíveis, e estes podem ser opacos ou translúcidos que permitem ou não a passagem de luz ao ambiente interno. A aplicação pode ser feita da mesma forma que revestimentos não aderidos, através de elementos de fixação, ou com os painéis compondo a esquadria, substituindo os vidros.

Interferência com outros subsistemas
Instalações elétricas;
Instalações hidráulicas, para aquecimento de água;
Vedações externas, pois são instalados na fachada ou cobertura do edifício.

Referências blibliográficas relacionadas a esta tecnologia

\section{U.S DEPARTMENT OF ENERGY, 2008}

ENERGY SAVING TRUST, 2007

www.institutoideal.org

NBR 11877:1991

\section{Quadro 4.12 - Painéis fotovoltaicos (sistemas de geração de energia).}




\section{PROCESSO DE TOMADA DE DECISÃO APLICADO À ESCOLHA DE TECNOLOGIAS CONSTRUTIVAS}

A tomada de decisão (item 3.1.2) exige a identificação clara da necessidade, a definição dos requisitos de escolha e a identificação das alternativas para que, assim, se possa decidir sobre quais das alternativas atendem aos requisitos e, portanto, à necessidade. Com o objetivo de auxiliar o processo, foram identificados requisitos de decisão (item 3.4) e foi realizado um levantamento de algumas tecnologias construtivas (item 4.2).

Neste item será discutida a aplicação do processo de decisão para a escolha de tecnologias construtivas em uma reabilitação, aplicando-se as informações levantadas sobre os critérios de decisão que deverão ser utilizados e as alternativas tecnológicas que podem atender a estes critérios.

O conjunto de tecnologias a ser aplicado em um edifício existente visando à sua reabilitação depende das suas características e do cenário em que está inserido. Ou seja, a combinação das tecnologias a serem utilizadas depende, não só dos níveis de sustentabilidade requeridos, mas também das características do edifício e de seu entorno que facilitam ou dificultam o alcance desses níveis de sustentabilidade.

Assim, confirma-se a necessidade de se apresentar diretrizes para que 0 processo de escolha das tecnologias possa ser aplicado em cada edifício especificamente, as quais são apresentadas na sequência. Essas diretrizes complementam as informações levantadas nos capítulos anteriores sobre requisitos de sustentabilidade aplicáveis à reabilitação (item 3.4); além das características tecnológicas e critérios apresentados nas fichas de tecnologias (quadro $x x$ a $x x$ ).

\subsection{Definição da diretriz balizadora do processo}

De acordo com o processo de tomada de decisão proposto, inicialmente devese definir as diretrizes balizadoras para a tomada de decisão, que serão a base para o desenvolvimento de todo o processo de decisão. Na proposta do 
presente trabalho, conforme discutido anteriormente, a diretriz balizadora para o processo de escolha de tecnologias construtivas para a reabilitação é a sustentabilidade, em que o objetivo principal é inserir tecnologias em um edifício para que ele se torne mais sustentável, sobretudo, do ponto de vista ambiental.

O processo de tomada de decisão para a escolha de tecnologias para a reabilitação foi feito para ser utilizado pelo projetista da reabilitação. Neste caso, constatada a necessidade de se reabilitar um edifício, o problema de decisão é optar pelo conjunto de tecnologias que, inseridas no edifício, proporcionará um grau de sustentabilidade adequado às exigências previamente estabelecidas, seja pelo cliente ou pelo usuário.

Conforme a Figura 3.2, após ser identificada a necessidade de escolha de tecnologias e a diretriz balizadora, o processo de tomada de decisão envolve etapas, ou seja, a caracterização do problema, a definição dos critérios de escolha e a identificação das alternativas, e possibilita, assim, a definição da melhor alternativa entre as levantadas. A seguir, são discutidas cada uma das etapas do processo.

\subsection{Caracterização do problema}

Inicialmente deve-se caracterizar o problema, que neste trabalho implica em selecionar um conjunto de alternativas para a reabilitação de um edifício ou de uma sua parte. Para isso, o primeiro passo é caracterizar precisamente o cenário em que essa decisão será tomada uma vez que a caracterização do problema irá depender deste cenário. Segundo Souza (2003), caso o cenário seja mal caracterizado, compromete-se a identificação do problema e a posterior formulação dos objetivos.

$\mathrm{Na}$ caracterização do problema considera-se, ainda, as limitações existentes, sejam limitações do próprio edifício (relacionadas às suas características, limitações de logística interna e organização do canteiro), da região (disponibilidade de materiais e serviços, legislação vigente, dificuldades de acesso), limitações relacionadas à cultura local, entre outras. 
Pode-se citar como exemplo um edifício localizado no centro da cidade de São Paulo, que deverá ser reabilitado para o mesmo fim.

Tendo em vista que o número de tecnologias pode ser muito grande, a título de exercício, propõe-se que as discussões acerca das diretrizes sejam focadas apenas na vedação vertical externa. Nesse caso, o problema da decisão é escolher qual tecnologia de fachada utilizar.

Para a caracterização do problema, deverão ser levantadas as informações, relativas ao ambiente externo e interno do edifício, que impactam na decisão. Algumas das informações relativas ao ambiente externo são:

- Condições climáticas: temperatura, incidência de ventos, incidência de chuva, insolação;

- Características legais da região: informações obtidas a partir de instruções técnicas municipais, do corpo de bombeiros, código de obras, plano diretor, entre outras, fornecidas pelos órgãos técnicos municipais, estaduais e federais;

- Cultura tecnológica local: principais tecnologias utilizadas na região, oportunidades e barreiras para utilização de novas tecnologias;

- Condições da localização do edifício no município: características do bairro em que está localizado, níveis de poluição sonora do local, proximidade de avenidas e áreas verdes, condições de acesso e tráfego local, distribuição de água e energia, e demais condições do entorno.

Entre as informações relacionadas ao ambiente interno do edifício, pode-se citar:

- Caracterização de uso do edifício: residencial, comercial, hoteleiro, industrial, etc.;

- Características arquitetônicas: posicionamento do edifício, áreas envidraçadas, ventilação, insolação, elementos de sombreamento existentes, entre outros; 
- Interface com os demais subsistemas: Tecnologias construtivas empregadas nos subsistemas do edifício que possuem alguma interface com a reabilitação em questão;

- Caracterização do(s) subsistema(s) objeto(s) da intervenção.

- Condição do edifício: levantada através de um diagnóstico detalhado do edifício a ser reabilitado, relativo às condições de conservação, patologias e possibilidade de aproveitamento dos elementos existentes;

- Potencial de aumento do grau de sustentabilidade ambiental: em relação aos requisitos especificados no item 3.4.

Considerando-se o exemplo anterior, de reabilitação da fachada de um edifício, para que o mesmo exercício possa ser feito nas demais etapas do processo de decisão, algumas características do ambiente interno e externo ao edifício a ser reabilitado serão consideradas, as quais: o edifício é comercial, e será reabilitado para o mesmo fim; está localizado ao lado de uma avenida de tráfego intenso; a fachada, de alvenaria, esquadrias de alumínio e vidros temperados, apresenta problemas de estanqueidade.

Caracterizado o problema, da tomada de decisão parte-se para a formulação dos objetivos.

\subsection{Formulação dos objetivos}

Nessa etapa deve-se estabelecer claramente quais são os objetivos, o principal e os específicos, quanto ao que se espera da adoção do conjunto de tecnologias em análise.

Considerando-se o exemplo anterior, em que o problema é a escolha da tecnologia de fachada para a reabilitação, o objetivo principal poderia ser enunciado como a melhoria da sustentabilidade ambiental do edifício.

A partir desse objetivo principal, deve-se considerar a caracterização do cenário, feita anteriormente, para especificar detalhadamente este objetivo. Os objetivos específicos podem estar relacionados a metas de redução de custos 
de operação, de nível de isolamento sonoro requerido para o ambiente interno, entre outros fatores.

Com referência ao exemplo da reabilitação de uma fachada, objetivos específicos poderiam ser:

- Reparar patologias existentes, como, por exemplo, problemas de estanqueidade;

- Aumentar a iluminação natural, reduzindo a quantidade de lâmpadas acesas durante o dia;

- Reduzir da transmissão sonora em relação ao ambiente externo.

Formulados os objetivos de decisão, parte-se para a definição dos critérios, a identificação das alternativas e sua avaliação de acordo com os critérios.

\subsection{Definição dos critérios de decisão}

No Capítulo 3, a partir das diretrizes estabelecidas, foram levantados os principais requisitos a serem considerados na escolha das tecnologias para a reabilitação, quais sejam: conforto térmico; conforto acústico; conforto visual; gestão de resíduos; otimização do desempenho energético; otimização do uso da água; relação com o entorno; e compatibilidade com a construção existente.

A partir desses requisitos principais, e de acordo com o cenário específico de cada edifício, deverão ser estabelecidos os critérios requeridos para que se possa atingir os objetivos formulados.

Para a reabilitação de uma fachada, por exemplo, os requisitos de sustentabilidade que se aplicam poderiam ser: conforto térmico, conforto acústico, conforto visual, gestão de resíduos, relação com o entorno e compatibilidade com a construção existente.

A partir desses requisitos definidos, podem ser estabelecidos diversos critérios de decisão, como, por exemplo, transmitância térmica da vedação, áreas de abertura para ventilação, sombreamento das aberturas, índices de redução 
sonora dos elementos da fachada, níveis de iluminação natural, volume de resíduos gerados durante a reabilitação, entre outros.

Além dos requisitos de sustentabilidade apresentados, outros podem ser incluídos no modelo de decisão, como a garantia da vida útil especificada, além dos custos globais de desenvolvimento de soluções, de execução e de implantação, uso e manutenção das tecnologias, relacionado ao requisito de sustentabilidade econômica.

Segundo Souza (2003), para a seleção dos critérios de avaliação, é necessário considerar o nível de complexidade do conjunto de alternativas. Se a alternativa considerada for somente um elemento construtivo do edifício, como por exemplo, as esquadrias de fachada, os critérios selecionados poderão ser simplificados em razão da facilidade de se obter informações sobre as características de desempenho do produto. Ainda segundo o autor, os critérios que devem ter prioridade durante a seleção são os que evidenciam as diferenças entre as alternativas. Por exemplo, se há duas alternativas avaliadas e ambas atendem ao critério de conforto térmico, esse critério pode ser descartado, pois a sua consideração não irá alterar a avaliação das alternativas.

Para a melhor compreensão dos itens a seguir, considerando o exemplo apresentado no item 5.2, de reabilitação de uma fachada de edifício, serão considerados como critérios de decisão para a escolha da melhor alternativa:

- Critério 1: índice de redução sonora ponderado dos elementos construtivos da fachada;

- Critério 2: nível de iluminação natural;

- Critério 3: área de abertura para ventilação de ambientes.

\subsection{Ponderação dos critérios de decisão}

No processo de projeto da reabilitação de um edifício, dependendo das suas características e das características do ambiente em que está situado, um 
critério pode ganhar grande importância no processo de decisão frente a outros.

Pode-se citar como exemplo o edifício Labor, estudado por Yolle Neto (2006). Construído na década de 1940, na região central da cidade de São Paulo. O edifício foi reabilitado adotando-se como elemento de vedação blocos cerâmicos. De acordo com o autor, o acréscimo de carga à estrutura, devido à tecnologia de vedação adotada, resultou em custos elevados de reforço estrutural. $\mathrm{O}$ autor salienta que, se as divisórias tivessem sido executadas com gesso acartonado ou com blocos de concreto celular autoclavado, haveria uma redução nos custos do reforço.

No caso do edifício Labor, a compatibilidade com a estrutura existente, previamente dimensionada para um edifício comercial, é um critério que deveria ter grande importância na decisão da tecnologia a ser utilizada nas vedações internas e não somente o custo unitário do vedo.

Em outros casos, alguns critérios de decisão podem ser desconsiderados pela sua baixa importância. Por exemplo, para um edifício localizado em uma região residencial, afastado de avenidas ou indústrias, não haverá a necessidade de se considerar o conforto acústico relacionado a ruídos externos, pois esta condição já é atendida pela característica da região.

Desta forma, de acordo com a importância de cada critério dentro do contexto da reabilitação, esses devem ser ponderados para que, na decisão, se tome como base os que forem mais relevantes. Essa ponderação é realizada atribuindo-se valores de importância a cada critério, de forma que para o mais importante seja atribuído o maior valor e, para o menos importante o menor.

Segundo Shimizu (2006), dependendo do nível de informação, do nível de assertividade requerido e do tempo disponível para a decisão, um ou mais critérios aos quais foram atribuídos os menores pesos poderão ser descartados.

De acordo com o método AHP, apresentado no capítulo 3, a ponderação de critérios pode ser realizada utilizando-se a Matriz de Comparação Paritária. A 
utilização desta ferramenta facilita a ponderação quando se possui mais de dois critérios de decisão. Como esta ponderação é, na maioria das vezes, subjetiva, ao se comparar o peso dos critérios aos pares, a análise torna-se mais simples e assertiva.

Tomando-se os exemplos de critérios apresentados no item 5.3, pode-se considerar as seguintes relações:

- Critério 1 versus critério 2: fortemente preferível (valor considerado na matriz: 5);

- Critério 3 versus critério 2: moderadamente preferível (valor considerado na matriz: 3);

- Critério 1 versus critério 3: moderadamente preferível (valor considerado na matriz: 3).

Considerando a escala de comparações da ASTM E 1765 (1998), apresentada no item 3.1.4.2, pode-se obter a matriz de comparação paritária (MCP) apresentada no Quadro 5.1. Em seguida, os pesos dos critérios são determinados considerando-se as prioridades relativas (Quadro 5.2).

\begin{tabular}{|c|c|c|c|}
\hline & $\begin{array}{c}\text { Critério } \\
1\end{array}$ & $\begin{array}{c}\text { Critério } \\
2\end{array}$ & $\begin{array}{c}\text { Critério } \\
3\end{array}$ \\
\hline $\begin{array}{c}\text { Critério } \\
1\end{array}$ & 1 & 5 & 3 \\
\hline $\begin{array}{c}\text { Critério } \\
2\end{array}$ & $1 / 5$ & 1 & $1 / 3$ \\
\hline $\begin{array}{c}\text { Critério } \\
3\end{array}$ & $1 / 3$ & 3 & 1 \\
\hline $\begin{array}{c}\text { Tot. da } \\
\text { coluna }\end{array}$ & $\mathbf{1 , 5 3}$ & $\mathbf{9}$ & $\mathbf{4 , 3 3}$ \\
Quadro 5.1 - Matriz de comparação paritária (MCP).
\end{tabular}

Os números apresentados no Quadro 5.2 correspondem à divisão do valor de cada critério pelo total da coluna, presente no Quadro 5.1 (conforme item 3.1.4.2). 


\begin{tabular}{|c|c|c|c|c|}
\hline & Critério 1 & Critério 2 & Critério 3 & Ponderação \\
\hline $\begin{array}{c}\text { Critério } \\
1\end{array}$ & 0,65 & 0,56 & 0,69 & $\mathbf{0 , 6 3}$ \\
\hline $\begin{array}{c}\text { Critério } \\
\mathbf{2}\end{array}$ & 0,13 & 0,11 & 0,08 & $\mathbf{0 , 1 1}$ \\
\hline $\begin{array}{c}\text { Critério } \\
3\end{array}$ & 0,22 & 0,33 & 0,23 & $\mathbf{0 , 2 6}$ \\
\hline $\begin{array}{c}\text { Tot. da } \\
\text { coluna }\end{array}$ & 1,00 & 1,00 & 1,00 & $\mathbf{1 , 0 0}$ \\
\hline
\end{tabular}

Quadro 5.2 - Ponderação dos critérios de decisão.

\subsection{Identificação das alternativas}

No contexto do presente trabalho, uma alternativa é um conjunto de tecnologias ou uma tecnologia que possibilitarão o completo atendimento aos critérios definidos e, por conseqüência, do objetivo estabelecido. Partindo deste pressuposto, a identificação das alternativas torna-se mais complexa, pois, ao se considerar a combinação das diferentes tecnologias para cada elemento do edifício, a quantidade de alternativas aumenta de forma exponencial.

Para exemplificar, pode-se considerar a reabilitação de um edifício residencial de múltiplos pavimentos, no qual o atendimento ao requisito de desempenho energético está relacionado às tecnologias que forem empregadas nas aberturas de fachada e esquadrias, nos sistema de climatização, nos sistema de iluminação, na forma de aquecimento da água, e em outras que, quando empregadas em conjunto, possibilitarão menor consumo de energia. A decisão, nesse caso, está relacionada à melhor combinação entre as tecnologias já incorporadas ao edifício que poderão ser reaproveitadas e as novas tecnologias a serem empregadas.

Souza (2003) salienta que, a partir das alternativas identificadas, deve-se optar por analisar aquelas que possuem maiores probabilidades de sucesso. Ou seja, no processo de formulação de alternativas deve-se fazer uma pré-seleção para se excluir aquelas inviáveis, por meio da aplicação das diretrizes balizadoras da metodologia.

Retornando ao exemplo da escolha de tecnologias de fachada, em um levantamento inicial, várias alternativas poderiam ser consideradas, entre elas: 
alvenaria em blocos de concreto, com revestimento monocamada e esquadrias de alumínio; fachada ventilada com vedo em alvenaria de blocos de concreto e placas cerâmicas fachada cortina envidraçada com vidros duplos, ou com vidros de baixa emissividade; light steel framming com revestimento em chapas cimentícias e esquadrias em PVC; painéis pré-moldados de concreto.

Para facilitar a aplicação do modelo de apoio à decisão (item 3.1.3), considerase conveniente que se faça uma pré-seleção. No exemplo, após uma préseleção, foram definidas duas alternativas:

- Alternativa 1: revestimento cerâmico não aderido fixado no vedo préexistente (alvenaria em blocos de concreto) e esquadrias de alumínio pivotantes com vidro laminado;

- Alternativa 2: fachada cortina envidraçada, com vidro laminado.

\subsection{Levantamento das informações de cada alternativa}

Para que se possa avaliar as vantagens e desvantagens de cada alternativa identificada, deve-se levantar o maior número possível de informações, de forma que se possa realizar uma análise comparativa entre as alternativas, de acordo com os critérios de decisão previamente estabelecidos.

Muitas vezes, a falta de informação sobre uma determinada tecnologia impossibilita a comparação entre as alternativas, sendo necessário buscar tais informações de forma mais específica, como por exemplo, pela realização de ensaios de laboratório, execução de protótipos, análise de especialistas, entre outras.

Além das informações técnicas, como o desempenho térmico ou consumo energético, também é necessário levantamento de informações de mercado relacionadas a estas tecnologias. A quantidade de fornecedores disponíveis, o nível de desenvolvimento destes fornecedores e da tecnologia em si; a qualificação da mão de obra para a implantação desta tecnologia; políticas governamentais para incentivo do uso de determinadas tecnologias; a 
legislação vigente na região, que pode limitar a utilização de tecnologias; e o custo são informações importantes a serem levantadas.

Contudo, mais do que informações específicas sobre cada tecnologia, é fundamental o levantamento de informações sobre como estas tecnologias trabalham em conjunto e a sua relação com 0 ambiente em que estão inseridas. Em alguns casos, é necessária a criação de modelos específicos para que se possa prever como as diferentes tecnologias irão se relacionar entre si e com o ambiente, podendo-se sustentar a qualidade da decisão a ser tomada.

Com relação ao requisito de compatibilidade com a construção existente, pode-se identificar as interferências entre diferentes subsistemas utilizando-se a modelagem BIM (Building Information Modeling). Essa ferramenta, porém, somente pode ser realizada após a avaliação do edifício e um diagnóstico detalhado dos elementos existentes, que permite identificar possíveis interferências, de modo a evitar surpresas durante a execução.

A simulação do desempenho, segundo Bessa (2010), tem por objetivo testar as diferentes possibilidades de projeto e compará-las até que se chegue ao projeto ideal, antes da construção ou reabilitação do edifício. A utilização de programas como o Energy Plus, por exemplo, possibilita o levantamento de informações importantes relacionadas à eficiência energética. A partir de dados de entrada fornecidos pelo usuário, com este programa pode-se calcular a carga de aquecimento e resfriamento para se manter o controle térmico do ambiente, bem como a energia consumida pelos equipamentos que realizam esse controle. Conforme a ABNT NBR 16401-1 (2008), exceto para sistemas muito simples, o cálculo da carga térmica se torna inviável sem o auxílio de um programa de computador.

No exemplo da reabilitação da fachada de um edifício, em que serão analisadas duas alternativas, ou seja, de revestimento cerâmico e esquadrias de alumínio (alternativa 1) e fachada cortina envidraçada (alternativa 2), quanto ao requisito de conforto acústico, para o critério 1 , que se refere ao índice de 
redução sonora ponderado dos elementos construtivos da fachada $\left(R_{\mathrm{w}}\right)$, podese tomar como referência os valores do Quadro 5.3.

\begin{tabular}{|c|c|}
\hline & $\mathrm{Rw}(\mathrm{dB})$ \\
\hline $\begin{array}{l}\text { Alvenaria de blocos de concreto }(14 \mathrm{~cm}) \text { com } \\
\text { revestimento }{ }^{1}\end{array}$ & 51 \\
\hline Vidro laminado de $12 \mathrm{~mm}^{2}$ & 35 \\
\hline \multirow{2}{*}{\multicolumn{2}{|c|}{$\begin{array}{l}\text { FRANCO,L.S. PCC } 2151 \text { - Alvenaria estrutural. Escola Politécnica da Universidade de São } \\
\text { Paulo. São Paulo, } 2007 .\end{array}$}} \\
\hline & \\
\hline${ }^{2}$ www.saint-gobain.com.br & \\
\hline
\end{tabular}

Quadro 5.3 - Índice de redução sonora ponderado da fachada, $\boldsymbol{R}_{\mathrm{w}}$.

Assim, o índice de redução sonora ponderado dos elementos da fachada $\left(R_{\mathrm{w}}\right)$ para alvenaria de blocos de concreto é de $51 \mathrm{~dB}$ e para vidro laminado de 35 $\mathrm{dB}$, conforme Quadro 5.3. Desta forma, para a alternativa 1, em que a fachada é constituída de mais de um componente, alvenaria e esquadrias, considera-se para o conjunto a situação mais desfavorável, que corresponde ao índice de redução de ruído com menor valor, ou seja, o do vidro (35dB).

Quanto ao critério 2, o nível de iluminação natural para cada alternativa é:

Alternativa 1: 60 lux

Alternativa 2: 100 lux

Com referência ao critério 3 , a área de abertura para ventilação de cada alternativa é:

Alternativa $1: 8 \mathrm{~m}^{2}$

Alternativa 2: $0 \mathrm{~m}^{2}$ 


\subsection{Avaliação e seleção das alternativas}

Levantadas as informações, pode-se então analisá-las de acordo com os critérios de decisão. Para isso, é necessário combinar as informações de cada alternativa com os critérios previamente estabelecidos. Existem critérios que são objetivos, os quais são facilmente comparáveis. O consumo de água é um exemplo de critério objetivo, em que uma alternativa é melhor quanto menor for o seu consumo de água.

Contudo, alguns critérios são subjetivos e, por isso, a comparação de alternativas depende do julgamento do decisor. Por mais informações que se tenha com relação à interação entre subsistemas e tecnologias, ou à facilidade de execução de uma ou outra alternativa, a comparação com base nesses critérios torna-se subjetiva. A subjetividade é causada pelas incertezas, tanto relacionadas ao edifício a ser reabilitado, quanto ao comportamento das tecnologias no ambiente em que serão inseridas.

No caso de critérios subjetivos, recomenda-se realizar uma avaliação qualitativa, atribuindo valores numéricos maiores às alternativas mais favoráveis ao atendimento daquele critério, e menores às mais desfavoráveis.

As alternativas que não atenderem ao mínimo estabelecido por algum critério devem ser descartadas. As demais poderão ser classificadas de diversas formas, de modo que sejam definidas as melhores alternativas para atendimento de cada critério específico.

O resultado dessa combinação é uma matriz na qual cada alternativa é apresentada com seus valores referentes a cada critério. Assim, uma alternativa pode ser melhor que outra em relação a um critério, porém ser pior em relação a outro.

Através do método AHP, descrito no capítulo 3, os valores dos critérios devem ser normalizados para facilitar a decisão. A partir daí, a alternativa que melhor atender aos diferentes critérios será considerada a melhor, e deverá ser escolhida. 
- Critério 1: índice de redução sonora ponderado dos elementos construtivos da fachada:

Para o critério 1 , como o desempenho acústico da fachada se dá, nas duas alternativas, pelo índice de redução sonora do vidro, se os vidros forem os mesmos, as duas alternativas terão o mesmo peso neste critério. Portanto:

Alternativa 1 versus Alternativa 2: igualmente preferível (valor considerado na matriz: 1).

- Critério 2: nível de iluminação natural

Para este critério, tem-se maior valor para a alternativa 2:

Alternativa 2 versus Alternativa 1: fortemente preferível (valor considerado na matriz: 5).

- Critério 3: área de aberturas para ventilação:

Neste caso, tem-se maior valor para a alternativa 1. Como a área de abertura para ventilação na alternativa 2 é igual a 0 , considera-se que:

Alternativa1 versus Alternativa 2: extremamente preferível (valor considerado na matriz: 9).

Analisadas as alternativas em relação a cada critério, pode-se chegar à classificação final multiplicando esses valores aos valores da ponderação dos critérios, feita no item 5.5 .

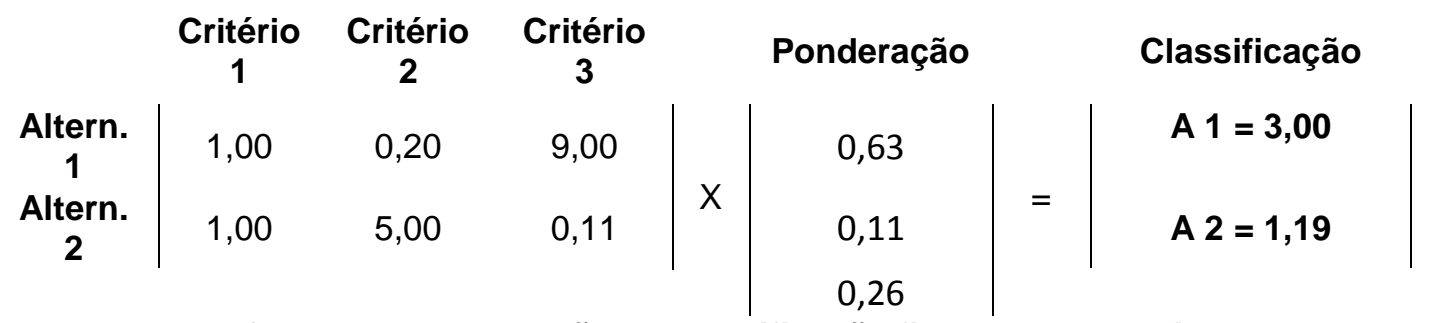

Quadro 5.4 - Obtenção da classificação final das alternativas.

Assim, conforme o Quadro 5.4, conclui-se que a melhor alternativa para este caso é a alternativa 2, ou seja, fachada cortina envidraçada, com vidro laminado. 


\section{CONSIDERAÇÕES FINAIS}

\subsection{Da consecução dos objetivos}

No presente trabalho, foi revisado o conceito de reabilitação de edifícios, bem como o contexto da execução deste tipo de intervenção no Brasil. De acordo com a bibliografia levantada, pode-se constatar que, nos edifícios antigos, grande parte dos subsistemas não atende aos requisitos de sustentabilidade hoje requeridos e aplicados em qualquer novo projeto. A partir daí, verificou-se a necessidade de implantar estes conceitos aos projetos de reabilitação, desde o projeto, a construção e operação, até o fim de sua vida útil.

Para a implantação de conceitos de sustentabilidade no processo de reabilitação de edifícios, é fundamental que se conheça as tecnologias existentes no mercado e que estas sejam aplicadas de forma a trazer benefícios aos usuários do edifício.

Contudo, mesmo conhecendo as possíveis alternativas disponíveis, a escolha do conjunto de tecnologias que melhor atendem às necessidades da reabilitação não é uma tarefa simples, e deve ser realizada considerando todas as variáveis que possam interferir nessa escolha. Seguindo este raciocínio, a dificuldade de escolha aumenta quanto maior a complexidade da reabilitação, ou maior o número de alternativas que podem ser empregadas.

Assim, a utilização de ferramentas para auxiliar o decisor neste processo de escolha pode trazer resultados positivos, como a identificação de alternativas que devem ser descartadas pelo não atendimento a um determinado requisito, podendo também facilitar a comparação entre diferentes alternativas, principalmente quando esta comparação é feita a partir de vários requisitos diferentes.

No presente trabalho, o objetivo de estabelecer um processo de tomada de decisão para a escolha de tecnologias para uma reabilitação sustentável não seria atendido apenas com uma definição das etapas do processo de decisão. Contudo, a definição dessas etapas, realizada no capítulo 3 , foi fundamental para se alcançar por completo esse objetivo. 
Uma das premissas adotadas durante 0 trabalho foi que, para auxiliar nesse processo de escolha, seria fundamental um levantamento de possíveis tecnologias a serem consideradas, sendo que esta demanda foi atendida no capítulo 4.

Com relação à definição dos requisitos, realizada no capítulo 3 , foi adotada a premissa de utilização dos requisitos de sustentabilidade para a decisão. A adoção dessa premissa justifica-se devido à necessidade de redução de impactos ambientais gerados pelos edifícios existentes.

Essa foi a principal motivação para a realização do presente trabalho, devido às oportunidades emergentes de crescimento das atividades de reabilitação no país. Assim como os empreendimentos de reabilitação de edifícios começam a surgir no Brasil, surge também a necessidade de se estudar essa atividade de forma mais profunda.

Considera-se que, através do presente trabalho, o decisor poderá realizar a escolha de tecnologias de forma mais estruturada, podendo assim obter melhores resultados na reabilitação de um edifício, com maior assertividade em suas decisões.

\subsection{Sugestões para trabalhos futuros}

No sentido de prosseguir com estudos relacionados ao tema do presente trabalho, entende-se a necessidade de se aplicar o processo proposto, para que se possa analisar os resultados em empreendimentos de reabilitação.

Para incrementar esse processo de tomada de decisão, mostra-se necessário a criação de um banco de dados referente à tecnologias para a reabilitação, para que se possa levantar informações sobre tecnologias de forma estruturada.

Outra necessidade é a análise mais profunda do processo de produção de empreendimentos de reabilitação. Diversas características da reabilitação apresentadas demonstram as oportunidades de estudos relacionados à gestão da produção de obras de reabilitação de edifícios. Questões relacionadas aos 
processos de produção da reabilitação, logística e planejamento, bem como a criação de ferramentas específicas para a gestão desse tipo de obra demandam estudos e devem ser tratadas em trabalhos futuros.

Por fim, a partir das metodologias de avaliação de sustentabilidade estudadas, entende-se como necessário o desenvolvimento de uma metodologia de avaliação da sustentabilidade da reabilitação aplicada ao Brasil. 


\section{REFERÊNCIAS BIBLIOGRÁFICAS}

AGUIAR, J.; CABRITA, A. M. R.; APPLETON. J. Guião de apoio à reabilitação de edifícios habitacionais. 7. ed. Lisboa: Laboratório Nacional de Engenharia Civil, 2005. 2 v.

AIKIVOURI, A.M. Periods and demand for private sector housing refurbishment. Construction Management and Economics. v. 14, p. 3 - 12. 1996.

AIKIVOURI, A.M. Critical loss of performance - what fails before durability. Durability of building materials and components. v. 8, p. $1369-1376.1999$.

AMERICAN SOCIETY FOR TESTING AND MATERIALS. Standard practice for applying analytical hierarchy process (AHP) to multiattribute decisions analysis of investiments related to buildings and building systems - ASTM E 1765-98. Annual Book of ASTM Standards. v. 04.11, p. 958-71, 1998.

ANDRESEN, I. et al. Sustainable Rehabilitation of Buildings: A State-ofthe-Art. Trondheim: Warsaw University of Technology, Warsaw, and Norwegian University of Science and Technology, 2004.

ARANTES, E.C. Diretrizes para reabilitação de edifícios - uso residencial em áreas centrais: o bairro de Santa Cecília. 2001. 182p. Dissertação (Mestrado) - Instituto de Pesquisas Tecnológicas do Estado de São Paulo IPT, São Paulo.

ARAÚJO, V.M. Práticas recomendadas para a gestão mais sustentável de canteiros de obras. 2009. Dissertação (Mestrado) - Escola Politécnica, Universidade de São Paulo, São Paulo.

ARUP. Existing buildings survival strategies - a guide for re-energising tired assets and reducing operating costs. Reino Unido, 2009. Disponível em <www.ukgbc.org/site/document/download/?document id=626>. Acesso em: agosto de 2010.

ASSOCIAÇÃO BRASILEIRA DE NORMAS TÉCNICAS. ABNT NBR 15758-2. Sistemas construtivos em chapas de gesso para drywall: projeto e 
procedimentos executivos para montagem - requisitos para sistemas usados como forro. 2009.

ASSOCIAÇÃO BRASILEIRA DE NORMAS TÉCNICAS. ABNT NBR 15575-1. Edifícios habitacionais de até cinco pavimentos- Desempenho. Parte 1: Requisitos gerais. 2008.

AULICINO, P. Análise de Métodos de Avaliação de Sustentabilidade do Ambiente Construído: O Caso dos Conjuntos Habitacionais. 2008. 143 p. Dissertação (Mestrado) - Escola Politécnica, Universidade de São Paulo, São Paulo.

BALL, R. Developers, regeneration and sustainability issues in the reuse of vacant industrial buildings. (1999) Building Research and Information v. 27 p. $140-148$.

BERNSTEIN, P.L. Have we replaced old-world superstitions with a dangerous reliance on numbers? Harvard Business Review, março/abril de 1996.

BERTELSEN, S. (a) Complexity - construction in a new perspective. In: Annual conference in the International Group for Lean Construction. Anais. Blacksburg, 2003.

BERTELSEN, S. (b) Construction as a complex system. In: Annual conference in the International Group for Lean Construction. Anais. Blacksburg, 2003.

BOMFIM, V.C. Espaços edificados vazios na área central da cidade de São Paulo e a dinâmica urbana. 2004. Dissertação (Mestrado) - Escola Politécnica, Universidade de São Paulo, São Paulo.

BRASIL. Lei $n^{\circ}$ 10.295, de 17 de outubro de 2001. Lei de eficiência energética.

BRASIL. Agenda 21 brasileira: Ações prioritárias / Comissão de Políticas de desenvolvimento sustentável e da Agenda 21 Nacional. 2. ed. Brasília: Ministério do Meio Ambiente, 2004. 158 p. 
BRASIL. Lei oํ 12.187, de 29 de dezembro de 2009. PNMC: política nacional sobre mudança do clima.

BRASIL. Plano nacional de eficiência energética. Brasília: Ministério de Minas e Energia, 2010.

BRE - Building Research Establishment. Quantifying the business benefits of sustainable buildings - Summary of existing research findings. Reino Unido: Centre for Sustainable Construction, BRE, 2001.

BRE - Building Research Establishment. BREEAM Scheme Document for New Construction: Technical Guide. Reino Unido: Centre for Sustainable Construction, BRE, 2011.

BRUNDTLAND, G.H. (Editor). Our common future: the world commission on environment and development. Oxford: Oxford University Press, 1987.

BUILDING TECHNOLOGY. Smart codes in your community: a guide to building rehabilitation codes. Estado Unidos, 2001. Disponível em: $<$ http://www.huduser.org/portal/publications/destech/smartcodes.html>. Acesso em 10 jul. 2010.

BULLEN, P.A. Adaptive reuse and sustainability of commercial buildings. Facilities. v. 25, n 1, p. $20-31.2007$

CÂMARA DA INDÚSTRIA DA CONSTRUÇÃO. Guia de Sustentabilidade na Construção. 60 p. Belo Horizonte: FIEMG, 2008.

CANTELL, S.F. The Adaptive Reuse of Historic Industrial Buildings: Regulation Barriers, Best Practices and Case Studies. 2005. Dissertação (Mestrado) - Virginia Polytechnic Institute and State University, Estados Unidos.

CARDOSO, F.F. Estratégias empresariais e novas formas de racionalização da produção no setor de edificações no Brasil e na França. Parte 2: do estratégico ao tático. Estudos Econômicos da Construção, SindusCon-SP, São Paulo, 1997. 
CASAGRANDE Jr., E. F. Inovação tecnológica e sustentabilidade: integrando as partes para proteger o todo. Paraná: Programa de PósGraduação em Tecnologia, Universidade Tecnológica Federal do Paraná, 2005.

CEOTTO, L. H. Avaliação de sustentabilidade: balanço e perspectivas no Brasil. In: Simpósio Brasileiro de Construção Sustentável - SBCS 08. Anais. São Paulo, 2008.

CERQUAL. Référentiel Patrimoine Habitat et Patrimoine Habitat \& Environnement - Millésime 2009. França: QUALITEL, 2009

CERTIVÉA. Démarche HQE®. Exploitation. Référentiel Technique des

Bâtiments Tertiaires en Exploitation. França: CERTIVÉA, 2008. Disponível em <http://www.certivea.fr>. Acesso em jul 2011.

CIB - INTERNATIONAL COUNCIL FOR RESEARCH AND INNOVATION IN BUILDING AND CONSTRUCTION. Agenda 21 on Sustainable Construction. CIB Report Publication 237. Rotterdam, 1999.

CIB - INTERNATIONAL COUNCIL FOR RESEARCH AND INNOVATION IN BUILDING AND CONSTRUCTION. Agenda 21 for Sustainable Construction in developing countries. United Nations Environment Programme. Africa do Sul, 2002.

CIOB - THE CHARTERED INSTITUTE OF BUILDING. Sustainability and Construction. Technical information.Reino Unido, 200-?. Disponível em: < www.ciob.org.uk/filegrab/sustainability.pdf?ref=74>. Acesso em 10 jul. 2010.

CLEMEN, R.T. Making hard decisions: an introduction to decision analysis. Belmont: Duxbury press, 1991.

CORCUERA, Daniela. Edifícios de Escritórios na Cidade de São Paulo: Componentes para Sistemas de Vedação Externa. 1999. Dissertação (Mestrado) - Faculdade de Arquitetura e Urbanismo, Universidade de São Paulo, São Paulo. 
COTELO, F.C. Revitalização do centro histórico de São Paulo e habitação popular: microeconomia e microgeografia. 2008. Tese (Doutorado) Fundação Getúlio Vargas, São Paulo.

CROITOR, E.P.N. A gestão de projetos aplicada à reabilitação de edifícios: estudo da interface entre projeto e obra. 2008. Dissertação (Mestrado) Escola Politécnica, Universidade de São Paulo, São Paulo.

CSTB - CENTRE SCIENTIFIQUE ET TECHNIQUE DU BÂTIMENT. A decision-making tool for selecting Office building upgrading solutions. TOBUS - Final report. 2000.

DAOUD, O.E.K. The architect/egineer's hole in rehabilitation work. Journal of construction engineering and management. V. 123. 1997.

DEGANI, C.M. Modelo de Gerenciamento da Sustentabilidade de Facilidades Construídas. 2009. 205p. Tese (doutorado) - Escola Politécnica, Universidade de São Paulo. 2009.

DEVECCHI, A.M. Reformar não é construir. A reabilitação de edifícios verticais: novas formas de morar em São Paulo no século XXI. 2010. Tese (Doutorado) - Faculdade de arquitetura e urbanismo, Universidade de São Paulo, São Paulo.

DTI - Department of Trade and Industrie. Review of sustainable construction. Reino Unido, 2006.

EGBU, C.O. Refurbishment management: challenges and opportunities. Building research and information. v. 25, n. 6. 1997.

EGBU, C.O.; YOUNG, B.A.; TORRANCE, V.B. Planning and control processes and techniques for refurbishment management. Construction Management and Economics. V. 16, p. $315-325.1998$

EGBU, C.O. Skills, knowledge and competencies for managing, construction refurbishment works. Construction Management and Economics. v.17, p. 29 - 43. 1999. 
ENERGY SAVING TRUST. Energy-efficient refurbishment of existing housing. 2009. Disponível em < www.est.org.uk/housingbuildings $>$. Acesso em maio de 2010.

ENKVIST, P; NAUCLER, T.; ROSANDER, J. A cost curve for greenhouse gás reduction. The McKinsey quarterly, n. 1. Estocolmo, 2007.

ERLICH, P.J. (a) Modelos quantitativos de apoio às decisões - I. Revista de administração de empresas, São Paulo, v. 36, n.1, p.33-41, 1996.

ERLICH, P.J. (b) Modelos quantitativos de apoio às decisões - II. Revista de administração de empresas, São Paulo, v. 36, n.2 p.44-52. 1996.

EUROCONSTRUCT CONFERENCE 2005. Cardiff, Grã Bretanha. Anais. Grã Bretanha: Euroconstruct, 2005.

FCAV - Fundação Carlos Alberto Vanzolini Referencial técnico de certificação "Edifícios habitacionais - Processo AQUA. São Paulo: Fundação Vanzolini, 2010.

FIOL, M. La toma de decisiones de directivos latinos. Revista de Administração de Empresas, v. 41, n. 4, p. 16-25, outubro/dezembro de 2001.

GRAEML, A.R. Considerações sobre limitações do processo decisório e a racionalidade das decisões humanas. Ciência \& Opinião, v. 1 n.2/4, p. $223-$ 244. 2004.

HARTKOPF, V.; LOFTNESS, V. Global relevance of total building performance. Automation in construction, v. 8, p. 377-393. 1999.

HESTNES, Anne Grete; KOFOED, Niels Ulrik. Effective retrofitting scenarios for energy efficiency and comfort: results of the design and evaluation activities within the OFFICE Project. Building and enviroment, n. 37 p. $569-$ 574. 2002.

HIGHFIELD, D. Refurbishment and upgrading of buildings. London: E\&FNSpoon, 2000. 
HM GOVERNMENT. Climate Change, the UK programme. Reino Unido, 2006.

HOLNESS, G.V.R. Sustaining our future by rebuilding our past. In: ASHRAE Journal. Agosto, 2009. Disponível em $<$ http://www.ashrae.org/aboutus/page/2372 > Acesso em agosto de 2010.

HUD - U.S. Department of Housing and Urban Development. Smart codes in your Community - A guide to Building Rehabilitation Codes. Washington D.C. 2001.

IBEC - Institute for Building Environment and Energy Conservation. CASBEE for new construction: Technical Manual. Edition. Japão: IBEC. 2008.

IBGE - Instituto Brasileiro de Geografia e Estatística. Sinopse do Censo Demográfico 2010. Rio de Janeiro, 2011

IGSHPA - INTERNATIONAL GROUND SOURCE HEAT PUMP ASSOCIATION. Disponível na Homepage da associação: $<$ www.igshpa.okstate.edu>. Acesso em: agosto de 2010.

IPCC - Intergovernmental Panel on Climate Change. Contribution of Working Groups I, II and III to the Fourth Assessment Report of the Intergovernmental Panel on Climate Change. p 104. Geneva, Switzerland, $2007 . \quad$ Disponível em: $<$ http://www.ipcc.ch/publications and data/ar4/syr/en/contents.html>. Acesso em 22 de fevereiro de 2010.

ITARD, L; KLUNDER, G. Comparing environmental impacts of renovated housing stock with new construction. Building research \& information, v. 35, p. $252-267.2007$

JOHN, V. M.; OLIVEIRA, D. P.; AGOPYAN, V. Critérios de sustentabilidade para a seleção de materiais e componentes - uma perspectiva de países em desenvolvimento. Departamento de Engenharia Civil, Universidade de São Paulo, 2006. 
JOHNSTONE, A Rehabilitation and reuse of existing buildings. Building maintenace and preservation: a guide to design and management. Architectural press. Oxford, 1996.

$\mathrm{KALBUSCH}, \mathrm{A}$. Critérios de avaliação de sustentabilidade ambiental dos sistemas prediais hidráulicos e sanitários em edifícios de escritórios. 2006. 162 p. Dissertação (Mestrado) - Escola Politécnica, Universidade de São Paulo. 2006.

KOHLER, N; HASSLER, U. The building stock as a research object. Building research \& information, v. 30 n.4, p. 226-236. 2002.

KÜHL, B.M. Restauração hoje: método, projeto e criatividade. Desígnio, v. 6, p. 19-34. 2006.

LAMBERTS, R; DUTRA, L; PEREIRA F. O. R. Eficiência Energética na Arquitetura. São Paulo: Editora PW, 1997. Disponível em: $<$ http://www.labeee.ufsc.br/arquivos/publicacoes/eficiencia_energetica_na_arqu itetura.pdf> Acesso em: 19 nov de 2009.

LANGSTON, C.; WONG, F.K.W.; HUI, E.C.M.; SHEN, L.Y. Strategic assessment of building adaptive reuse opportunities in Hong Kong. Building and Environment. V. 43, p. 1709 - 1718. 2008.

LANZINHA, J.C.G. Exploração de Metodologia de Diagnóstico Exigencial de apoio à reabilitação de edifícios de habitação. $2^{\circ}$ Encontro sobre Patologia e Reabilitação de Edifícios, Patorreb. Porto, 2006.

LARSSON, N. Building performance assessment, SB Method and SBTool. Disponível em: <http://www.iisbe.org/sbmethod-2010>. Acesso em jun. 2011.

MANSFIELD, J.R. Complexities in the definition of "refurbishment". Property Management. v. 20, n 1, p. $23-30.2002$.

MARCH, J. G.; SIMON, H. A. Teoria das organizações. Trad.: Hugo Wahrlich, Rio de Janeiro, Fundação Getúlio Vargas. Serviço de Publicações, 1967. 
MARQUES DE JESUS, C.R. Análise de custos para reabilitação de edifícios para habitação. 2008. Dissertação (Mestrado) - Escola Politécnica, Universidade de São Paulo, São Paulo.

MARQUES DE JESUS, C.R.; BARROS, M. M. S. B. Reabilitação de edifícios: a importância dos sistemas prediais. Revista Techné. Ed.156, p.60 - 65, março de 2010.

MIRANDA, F. Habitação no centro. O Estado de São Paulo. 6 fev. de 2010. MONKS, J. Administração da Produção. São Paulo: McGraw-Hill, 1985.

OEE - OFFICE OF ENERGY EFFICIENCY. Guide to Canada's Energy Efficiency Regulations. Canadá: 2009 Disponível em: < http://oee.nrcan.gc.ca/regulations/guide.cfm?attr=0 > . Último acesso: junho de 2011.

OLIVEIRA, L. A. Metodologia para desenvolvimento de projeto de fachadas leves. 2009. 267 p. Tese (Doutorado) - Escola Politécnica da Universidade de São Paulo. Departamento de Engenharia de Construção Civil.

ONU - ORGANIZAÇÃO DAS NAÇÕES UNIDAS. Agenda 21 global. Conferência das Nações Unidas sobre Meio Ambiente e Desenvolvimento. Rio de Janeiro: 1992.

ONU - ORGANIZAÇÃO DAS NAÇÕES UNIDAS. Protocolo de Kyoto. Convenção Quadro das Nações Unidas sobre Mudança Climática. Secretaria Geral da ONU Nova lorque Estados Unidos: 1998.

PAIVA, J.; AGUIAR, J.; PINHO, A. Guia Técnico de Reabilitação Habitacional. Volume 2, 1. ed. Lisboa: Editora INH e LNEC, 2006.

PICCHI, F.A. Sistemas da Qualidade: Uso em Empresas de Construção de Edifícios. 1993. 462 f. Tese (Doutorado) - Escola Politécnica, Universidade de São Paulo, São Paulo.

POON, C.S. Management and recycling of demolition waste in Hong Kong. Waste Management and Research, Volume 15, p. 561-572. 1997. 
REABILITA. Diretrizes para Reabilitação de Edifícios - as experiências em São Paulo, Salvador e Rio de Janeiro. Organizadores: Witold Zmitrowicz, Veléria Cusinato Bomfim. São Paulo, 2007.

REMY, J.J. As empresas e política de reabilitação na França. In: Seminário Internacional de Reabilitação do Centro de São Paulo: novas oportunidades para o mercado imobiliário, 2003. Anais...São Paulo, 2003.

ROBBINS, S.P. Comportamento Organizacional. $8^{\mathrm{a}}$ ed. Rio de Janeiro: LTC, 1999.

RODERS, A.R.G.M.M.P. RE-ARCHITECTURE: Lifespan rehabilitation of built heritage. Technische Universiteit Eindhoven. 231 p. 2007.

ROCHA, C.A.L. O gesso na indústria da construção civil: Considerações econômicas sobre utilização de blocos de gesso. 2007. Dissertação (Mestrado) - Universidade Federal de Pernambuco, Recife.

SAATY, T.L. Método de análise hierárquica. São Paulo: McGraw-Hill, 1991.

SABBATINI, F.H. Desenvolvimento de métodos, processos e sistemas construtivos - formulação e aplicação de uma metodologia. 1989. Tese (Doutorado) - Escola Politécnica, Universidade de São Paulo, São Paulo.

SALOMON, V.P. ; MONTEVECHI, J.A.B. ; PAMPLONA, E.O. Justificativas para aplicação do método de análise hierárquica. 19 ENEGEP. Rio de Janeiro, 1999.

SANTAMOURIS, M. Passive retrofitting of Office buildings to improve their energy performance and indoor working conditions. Building and environment, v. 37, p. 555-556, 2002.

SANTAMOURIS, M.; DASCALAKI, E. Passive retrofitting of office buildings to improve their energy performance and indoor environment: the OFFICE Project. Building and Environment, n. 37575 - 578. 2002. 
SCHMIDT, A.M.A. Processo de apoio à tomada de decisão abordagens: AHP e MACBETH. 1995. Dissertação (Mestrado) - Universidade Federal de Santa Catarina, Florianópolis.

SDC - SUSTAINABLE DEVELOPMENT COMMISSION. Sustainable development in government - annual report 2007. Reino Unido, 2008. Disponível em:

$\leq \mathrm{http}: / / . \mathrm{sd}-$ commission.org.uk/publications/downloads/sdig report 2007.pdf>. Acesso em: agosto de 2010.

SEELEY, I. Building maintenance. Estados Unidos: Editora Macmillan, 2. ed. Basingstoke, 1987.

SHIMIZU, Tamio. Decisão nas organizações. São Paulo: Atlas, 2006.

SILVA, V. G. Avaliação da sustentabilidade de edifícios de escritórios brasileiros: diretrizes e base metodológica. 2003. 210 p. Tese (Doutorado) Escola Politécnica, Universidade de São Paulo, São Paulo.

SIMON, H.A. Administrative Behavior: a study of decision making processes in administrative organizations. Estados Unidos: McMillan, 2. ed. New York, 1957.

SOUZA, J.C.S. Metodologia de análise e seleção de inovações tecnológicas na construção de edifícios: aplicação para vedação vertical de gesso acartonado. 2003. 205 p. Tese (Doutorado) - Escola Politécnica, Universidade de São Paulo, São Paulo.

TANIGUTTI, E. K.; BARROS, M. M. S. B. Recomendações para a produção de vedações verticais para edifícios com placa de gesso acartonado. São Paulo: EPUSP/SENAI, 1998. 47p.

U.S. DEPARTMENT OF ENERGY. Buildings energy data book. Estados Unidos: D\&R International, Ltd., 2009.

USGBC - U.S. GREEN BUILDING COUNCIL. LEED 2009 for New Construction and Major Renovations. Estado Unidos: U.S. Green Building Council, 2009. 
VAN DER VOORDT, T. J. M; VAN WEGEN, H. B. R. Architecture in Use. An introduction to the programming, design and evaluation of buildings. Holanda: Elsevier, Architectural Press. Bussum, 2005.

VIJVERBERG, G. Accommodation functionality assessment in office buildings. Facilities. v. 20, p. 94-103. 2002.

WILKINSON, S. REED, R . The Business Case for incorporating sustainability in office buildings: the adaptive reuse of existing buildings. 14th Annual Pacific Rim Real Estate Society Conference. Malásia, 2008.

WORLD BUSINESS COUNCIL FOR SUSTAINABLE DEVELOPMENT. (a) Eficiência energética em edifícios: realidades empresariais e oportunidades. Relatório síntese. 2009.

WORLD BUSINESS COUNCIL FOR SUSTAINABLE DEVELOPMENT. (b) Energy efficiency in buildings: transforming the market. 2009.

YOLLE NETO, J. Diretrizes para estudo de viabilidade da reabilitação de edifícios antigos na região central de São Paulo visando a produção de HIS: estudo de casos inserido no Programa de Arrendamento Residencial (PAR). 2006. Dissertação (Mestrado) - Escola Politécnica, Universidade de São Paulo, São Paulo. 